University of Louisville

ThinkIR: The University of Louisville's Institutional Repository

Electronic Theses and Dissertations

8-2010

\title{
The impact of parental risk factors on child outcomes : examining parental incarceration within a multiple-risk model.
}

Melody Lynn Hyppolite 1976-

University of Louisville

Follow this and additional works at: https://ir.library.louisville.edu/etd

\section{Recommended Citation}

Hyppolite, Melody Lynn 1976-, "The impact of parental risk factors on child outcomes : examining parental incarceration within a multiple-risk model." (2010). Electronic Theses and Dissertations. Paper 658.

https://doi.org/10.18297/etd/658

This Doctoral Dissertation is brought to you for free and open access by ThinkIR: The University of Louisville's Institutional Repository. It has been accepted for inclusion in Electronic Theses and Dissertations by an authorized administrator of ThinkIR: The University of Louisville's Institutional Repository. This title appears here courtesy of the author, who has retained all other copyrights. For more information, please contact thinkir@louisville.edu. 
THE IMPACT OF PARENTAL RISK FACTORS ON CHILD OUTCOMES: EXAMINING PARENTAL INCARCERATION WITHIN A MULTIPLE-RISK MODEL

\author{
By \\ Melody Lynn Hyppolite \\ B.S., Kentucky Wesleyan College, 1998 \\ M.S.W., Spalding University, 2002

\begin{abstract}
A Dissertation
Submitted to the Faculty of the

Kent School of Social Work of the University of Louisville

In Partial Fulfillment of the Requirements

for the Degree of
\end{abstract}

Doctor of Philosophy

University of Louisville

Louisville, Kentucky

August 2010 
Copyright 2010 by Melody Lynn Hyppolite

All rights reserved 
THE IMPACT OF PARENTAL RISK FACTORS ON CHILD OUTCOMES: EXAMINING PARENTAL INCARCERATION WITHIN A MULTIPLE-RISK MODEL

\author{
By
}

Melody L. Hyppolite

B.S., Kentucky Wesleyan College, 1998

M.S.W., Spalding University, 2002

A Dissertation Approved on

July 5,2010

by the following Dissertation Committee:

Dissertation Director, Seana Golder, Ph.D.

Ruth Huber, Ph.D.

Bibhuti Sar, Ph.D.

Patrick McKiernan, Ph.D.

Gretchen Ely, Ph.D. 


\section{DEDICATION}

This dissertation is dedicated to my husband

Judex Hyppolite.

Your support, guidance, and encouragement made a made a very difficult task more tolerable. Thank you. 


\section{ACKNOWLEDGMENTS}

I would like to thank Dr. Seana Golder for her unwavering support, guidance, and patience. Her confidence in me helped me to keep moving forward even when I couldn't always find the confidence in myself. My respect for her runs deep, not only as a scholar but as a woman and a person. I would also like to thank the other committee members, Dr.'s Ruth Huber, Bibhuti Sar, Patrick McKeirnan, and Gretchen Ely. Their suggestions and feedback allowed me to strengthen my research. Thank you to my friends and colleagues in the doctoral program who struggled along beside me. Your friendships are something very valuable that I take away with me from this experience. Also, many thanks to my mother and father, Sheila and Carl Allen. They have always encouraged me to go after my dreams and their support of me has never faltered. Finally, I would like to thank my husband, Judex, for his support, understanding, and guidance. He wouldn't let me give up, even when I thought l'd never see the light at the end of the tunnel. To all of you, again, my deepest thanks and gratitude. 


\section{ABSTRACT \\ THE IMPACT OF PARENTAL RISK FACTORS ON CHILD OUTCOMES: EXAMINING PARENTAL INCARCERATION WITHIN IN A MULTIPLE-RISK MODEL \\ Melody L. Hyppolite}

July 5,2010

The impact of four primary parental risk factors (parental mental illness, parental substance use, parental mental illness, and poverty) on seven child outcomes (school failure, criminal behaviors, being arrested, behavioral difficulties, emotional difficulties, alcohol, and drug use) was examined. The accumulation of multiple risk factors in a child's life was found to significantly increase the likelihood that several negative outcomes would occur. The research, however, suggests further that this is an over simplification of the phenomenon and that specific risk factors are more likely to contribute to specific child outcomes. Depending on the outcome being addressed by programming and policies it would be beneficial to address those risks found to be more significantly linked to that specific outcome. 
TABLE OF CONTENTS

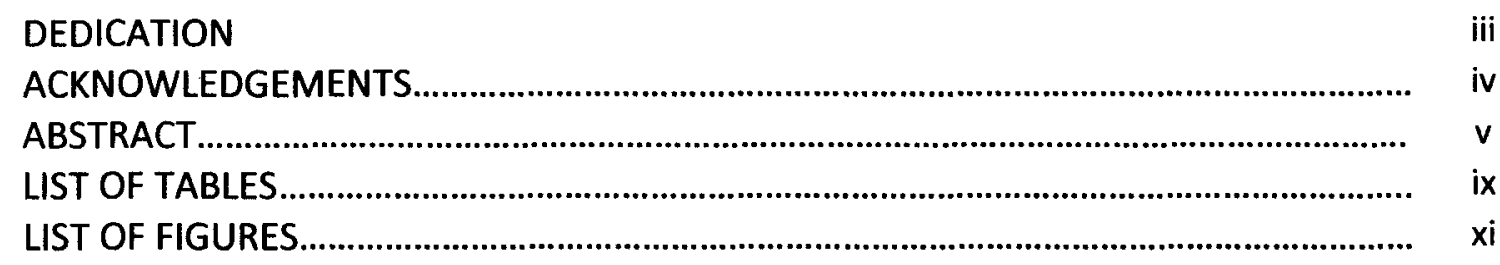

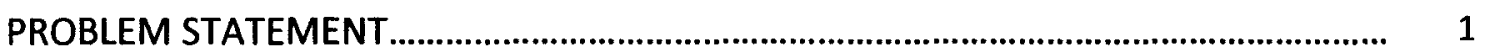

Mass Incarceration in the United States...........................................................

Who is in prison? ................................................................... 8

A look at the numbers-Kentucky and the United States................... 9

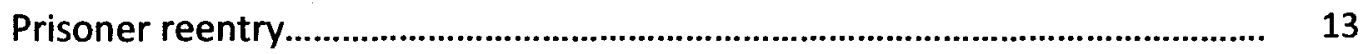

Scope of the Problem -Children with an Incarcerated Parent....................... 16

Characteristics of incarcerated parents............................................ 17

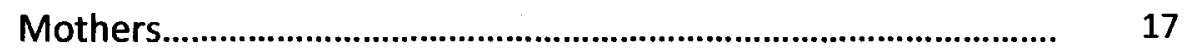

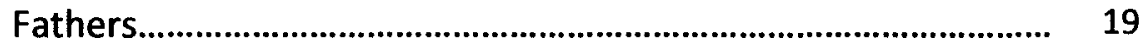

Role of Other Risk Factors............................................................................ 20

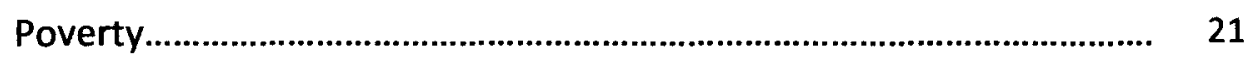

Parental substance use....................................................................... 21

Parental mental illness...................................................................... 22

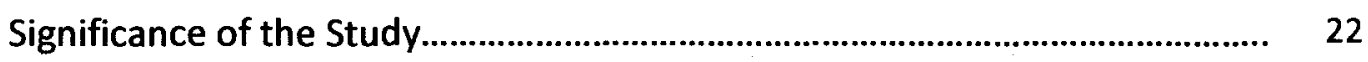

Research Questions and Hypotheses.......................................................... 24 
Plans for the Chapters.................................................................................... 24

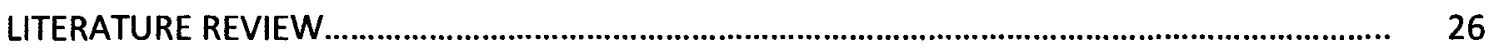

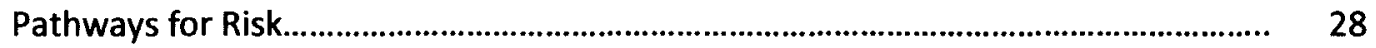

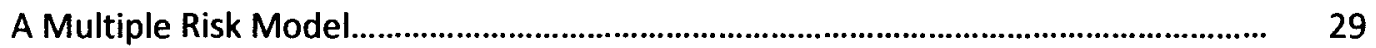

Poverty and negative child outcomes......................................................... 32

Parental substance use and negative child outcomes..................................... 39

Parental mental illness and negative child outcomes...................................... 42

Parental incarceration and negative child outcomes....................................... 47

Poverty due to incarceration............................................................ 48

Parental separation and maintaining parent child relationships...... $\quad 49$

Emotional impact (stigma, grief, and attachment)......................... 51

Childcare and placement during imprisonment................................. 53

Parent-child reunification................................................................... 53

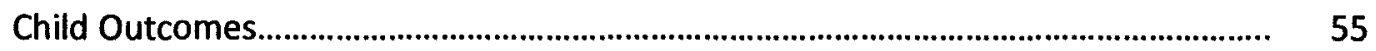

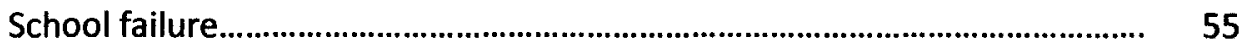

Emotional/behavioral difficulties............................................................... 57

Criminal behaviors................................................................................... 58

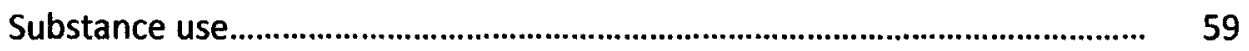

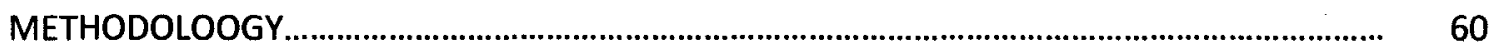

Sample: The Children at Risk Program (CAR) .......................................................... 60

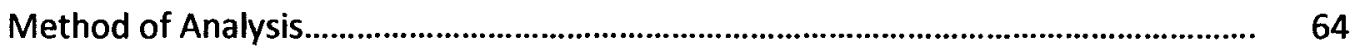

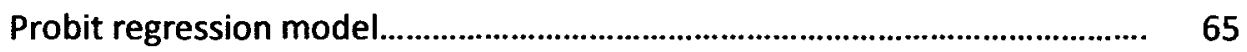

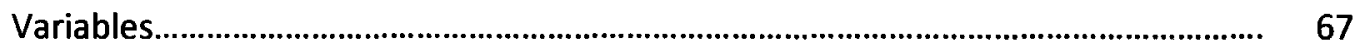

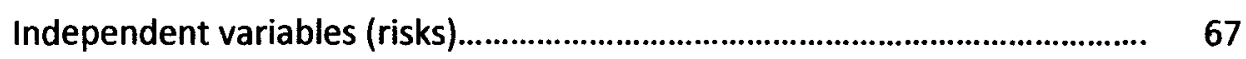


Introduction

Demographics.

Regression Results.

Understanding probit regression

Effects and predicted outcome probabilities.

Post-hoc Analyses.

Sub-group differences.

Protective Factors

Probit regression results.

Effects on outcome probabilities

DISCUSSION

Research Questions Addressed

Research Question One.

Research Questions Two.

Post-hoc Analyses and Opportunities for Future Research

Protective factors. 


\section{LIST OF TABLES}

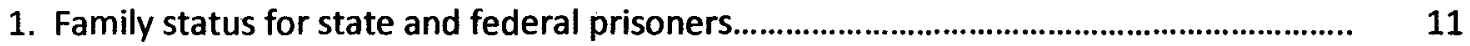

2. Living arrangements for state and federal prisoners prior to incarceration.................... 12

3. Location of children during a parent's incarceration.......................................................... 13

4. Persistence of poverty from childhood through early adulthood...................................... 35

5. Selected population-based indicators of well-being for poor and nonpoor children in $\quad 37$ the United States.

6. Correlations among dependent variables (outcomes) ............................................................ 66

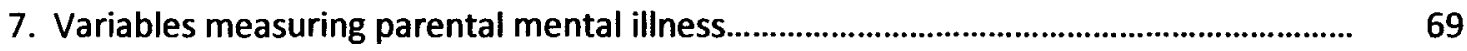

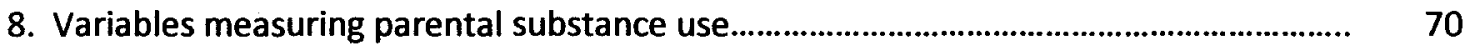

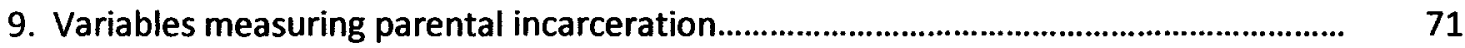

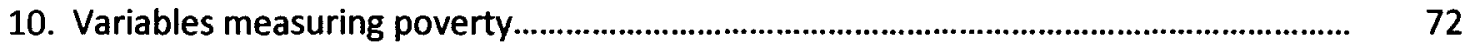

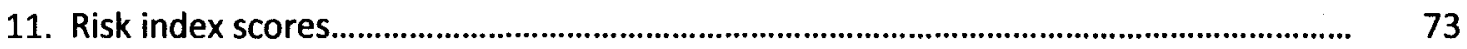

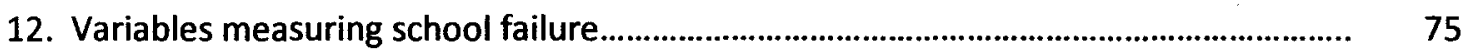

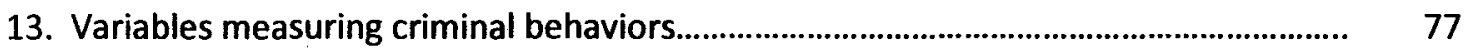

14. Variables measuring criminal behaviors and being arrested........................................... 78

15. Variables measuring emotional and behavioral difficulities.............................................. 79

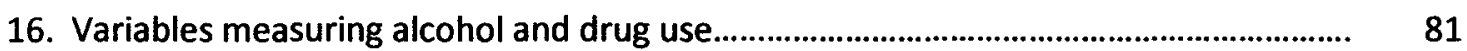

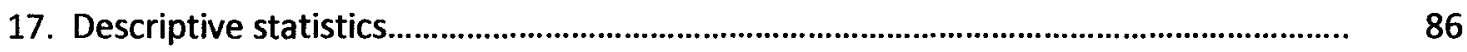

18. Correlations among independent variables (risk factors) ............................................... 87

19. Correlations among dependent variables (outcomes) ....................................................... 87

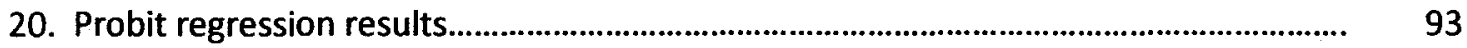




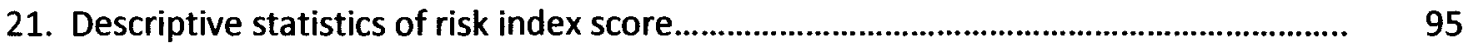

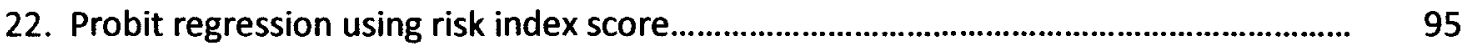

23. Predicted probability of school failure............................................................................ 96

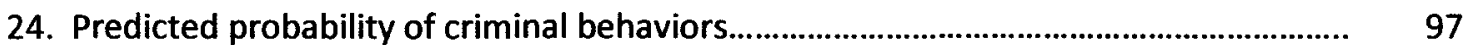

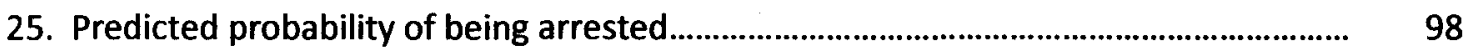

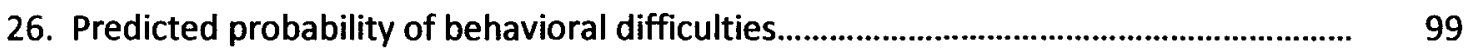

27. Predicted probability of emotional difficulties.................................................................. 100

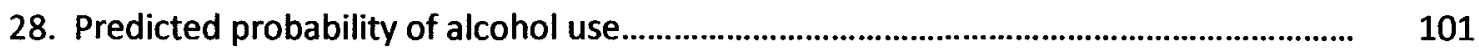

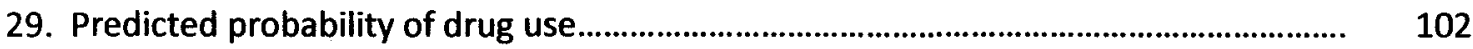

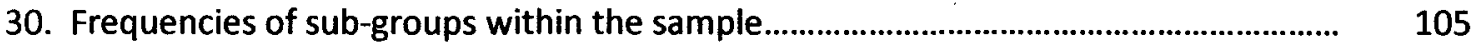

31. Probit regression with protective factors......................................................................... 108

32. Probit regression using risk index and protective factors............................................. 110

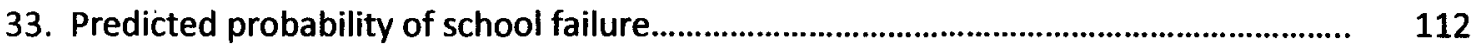

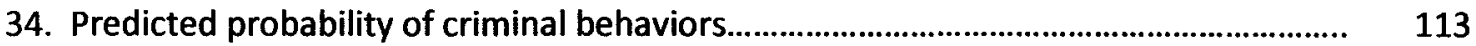

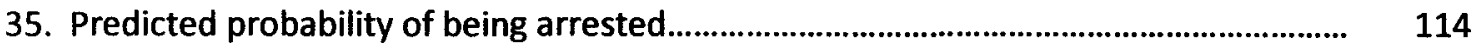

36. Predicted probability of behavioral difficulties.............................................................. 115

37. Predicted probability of emotional difficulties............................................................... 116

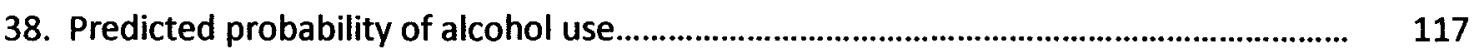

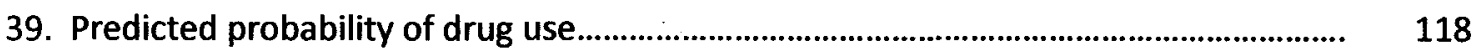




\section{LIST OF FIGURES}

$\begin{array}{ll}\text { FIGURE } & \text { PAGE }\end{array}$

1. A multiple risk model: poverty...........................................................................

2. A multiple risk model: poverty, parental mental illness.................................... 39

3. A multiple risk model: poverty, parental mental illness, parental 42

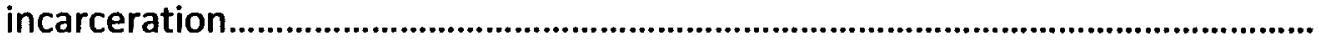

4. A multiple risk model: poverty, parental mental illness, parental 46

incarceration, and poverty...............................................................................................

5. The ties that bind........................................................................................... 


\section{CHAPTER I}

\section{PROBLEM STATEMENT}

Your children are not your children. They are the sons and daughters of Life's longing for itself. They came through you, but not from you, and though they are with you yet they belong not to you.

Kahlil Gibran

The Masai tribe of Africa, considered to be one of the most fearsome and intelligent among the tribes, use a traditional greeting of Kasserian Ingera or and how are the children? This greeting acknowledges the high value of children in their society. When warriors respond that all the children are well it indicates that peace and safety reign and the priorities of protecting the young and powerless are in proper order (Jones, 2008).

In American society these priorities are less evident as millions of children suffer the collateral consequences of our war on drugs and war on crime (Travis, 2002). Children are separated from their parent(s) and childhoods, that are many times already difficult, are further characterized by deprivation, poverty, and shame. The impact of incarceration on children is not well understood, but many researchers (Arditti, Lambert-Shute, \& Joest, 2003; Johnson \& Waldfogel, 2004; Johnson, 2009; Phillips, Burns, Wagner, Kramer, \& Robbins, 2002) assert 
that it leads to negative outcomes including academic underachievement, criminal behaviors, and substance abuse. What could be expected from American children and families if everyone took equal responsibility for the daily care and protection of American children? Every town leader, law enforcement officer, preacher, governor, policy maker, clergy, teacher, citizen asks the question: And how are the children? What would their answers be?

Human life is complex and so too are the lives of our children. These children often times face unknown challenges and hardships long before they ever lose a parent to incarceration. Having a parent incarcerated is only the most recent thing to happen to these children. Research supports that many of these children already struggle with the challenges of having a parent facing mental illness, addiction, and poverty, all of which have been found to contribute substantially to negative child outcomes (Anda et al., 2002; Downey \& Coyne, 1990; McLeod \& Shanahan, 1993; Moe, Johnson, \& Wade, 2007; Oyersman, Bybee, \& Mowbray, 2002). Therefore, while the impact of loss through incarceration is unquestionable, it is also necessary to examine the effect of other life variables that many of these children face. To better serve this vulnerable population it is necessary to understand the multiple risk factors, including parental incarceration, that interact to affect children's outcomes. This paper explores the challenges faced by the children of incarcerated parents, but saying that simply the incarceration of a parent leads to negative outcomes is an over-simplification of a very complex issue. It is also important to delve into a more deep rooted issue, the combination of multiple factors. Risk factors that 
often occur in tandem, including poverty, parental substance use and parental mental illness, and the increased risk of parental incarceration as the United States incarcerates more and more people each year.

\section{Mass Incarceration in the United States}

Confining people who harm us is an ancient concept within society. Unable to execute or banish all of those who cause harm, society has continually turned to prisons as a solution. Early prisons were punitive and controlling, using internal regimes that were intentionally inhumane. The purpose of these early prisons was incapacitation and institutions were marked by neglect and brutality. Early American prisons, constructed after the Revolution, were not meant to be places of corrections, but rather forbidding specters of punishment and deterrence. Later reforms would lead to the penitentiary, which was asserted to be a place of corrections, and later the correctional institution whose focus returned to rehabilitation. Prison environments became more relaxed and correctional programs slowly became available, although they often lacked substance (Walker, 2001). From the mid-1960s to the present, prison environments have largely ignored rehabilitation efforts and prisons today are marked by violence and predation (Austin \& John, 2001; Reiman, 1998). The environment within today's prisons is alarmingly similar to urban slums, and the $21^{\text {st }}$ century prison seems to have evolved from a stable if oppressive Big House, through a brief attempt at corrections, to what amounts to a contained but turbulent ghetto (Austin \& John, 2001; Johnson, 2002; Walker, 2001). 
Several federal and state policy changes have made incarceration an increasing presence in the lives of American citizens, especially men of color and men with low educational levels. The federal government's get tough on crime policies, from Nixon's war on crime and Reagan's war on drugs, to the more punitive stances toward violent crimes that came from the first Bush and Clinton administrations, have all led to a ballooning of prison populations over the last 50 years (Herivel \& Wright, 2003; Swisher \& Waller, 2008). Federal and state mandatory minimum laws, three-strike legislation, and increased funding for building prisons are only a few of the detrimental policy changes that have come from these efforts (Austin \& John, 2001). Many states have reformed parole policies making parole more difficult to obtain and have placed restrictions on public assistance programs further increasing the difficulties that those released from prison, and therefore their families, face upon reentry to the community (Johnson, 2002; Reiman, 1998; Swisher \& Waller, 2008).

The following graphs from the Department of Justice illustrate the ballooning of the prison population in the United States (DOJ, 2007a, 2007b). 

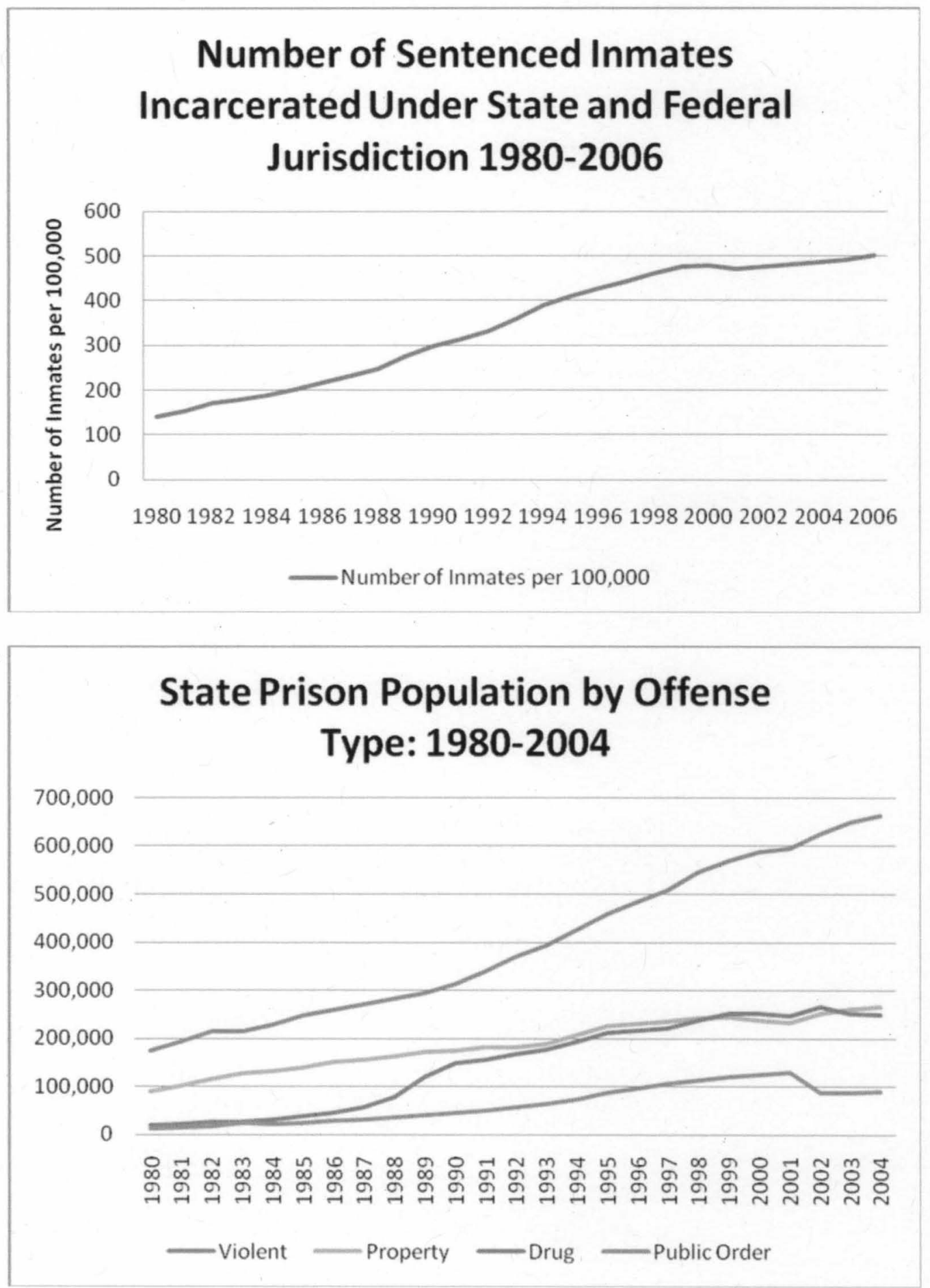

Society often forgets that when men or women are incarcerated they often leave children and families behind. These innocent bystanders to their parents' crimes carry heavy burdens of grief and confusion and are at high risk of 
following in the criminal footsteps of their parent(s) (La Vigne, Davies, \& Brazzell, 2008; Moses, 1995). Punitive attitudes toward crime have overlooked or ignored the impact that the incarceration boom in the United States has heaped upon some of the most vulnerable in our country.

Braman and Wood (2003) tell the story of Davida, who witnessed the arrest of her father.

I remember the night the police came. They chased him in the house, and I was sitting there screaming, like "Daddy! Daddy!" And he ran to the back door, but the back door was locked. The police came, and they pushed him down on the floor. He got up and pushed them off and ran through the front door, so I ran behind him, and I was just running right behind him. . . running right behind him. I seen the police behind me, and my father ran in the through the alley. And I came, and I seen the police coming, so I ran behind the gate, by where my father was at. They didn't see us. My father, they came and pulled my father from under the car and started beating him. And I was standing there looking at them beating my father with night sticks, and they dragged him through the alley and put him in the paddy wagon. So they took my father (p. 157).

Davida was "upset by that" (Braman \& Wood, 2003, p.158) and started drinking and dropped out of school in the sixth grade. Over the next four years of her life she would experience sexual abuse at the hands of her step-father, serve 
time in a juvenile facility, sell her body to support herself and her grandmother (her caregiver) and spend time in a psychiatric institution. She explains the hardships that she is facing during her father's period of incarceration.

My father is very important to me and grandmother, because by me not being old enough to get a regular job that maintains a stable place for us to stay, and my grandmother's retired, she only gets one check a month, we don't have much money to do this, or, you know, food or whatever. She's not with Section 8 yet, public housing, food stamps, so it's, like, my father needs to be here. . . I'm bending over backwards trying to keep everything intact while he's not here, and by me being my age it's hard, you know? I'm going through a hell of a life while he's not home (Braman \& Wood, 2003, p. 158).

Davida's story is not the only one to be reshaped by incarceration. Millions of families like hers are suffering the effects of our expanding prison populations (Braman \& Wood, 2003; Clear, 2002; Travis, McBride, \& Solomon, 2003; Travis \& Ward, 2003). Incarceration is based on a theory of public safety called addition by subtraction. The theory asserts that when people are removed from their communities the deficits created by their presence in the community are subtracted. The assumption is that removing these people subtracts only, or mainly, the problems they represented, therefore leaving the community better off. The theory fails to recognize the valuable assets that are also removed from 
not only the broader community, but perhaps more importantly, the family (Clear, 2002).

\section{Who is in prison?}

Understanding the impact of incarceration on children and families requires an understanding of who is in prison, the characteristics of the families most impacted, and the challenges the families face both during incarceration and after release. Much of the growth that has occurred in the correctional system has been among minority groups. This growth is most significant among the African American population, but it can also be seen among the Hispanic community and other minority groups in this country (Lewis, March 12, 2002). Mauer (as cited in Lewis, March 12, 2002) asks the question; What does it mean to a community...to know that three out of ten boys growing up will spend time in prison? What does it do to the fabric of the family and community to have such a substantial proportion of its young men enmeshed in the criminal justice system? What images and values are communicated to young people who see the prisoner as the most prominent or pervasive role model in the community? What is the effect on a community's political influence when one quarter of the black men in some states cannot vote as a result of a felony conviction? (p.1) Society does not send these men and women to prison with the intention, or even the hope, of rehabilitation (Austin \& John, 2001). Despite this, many of today's prisons do offer limited services aimed at rehabilitation or preparation for 
those within the walls of the prison for life outside. Unfortunately, the rapid growth of the prison population has overwhelmed the system and the limited services and programs available are grossly inadequate to meet the need for services. The men and women who enter the system without needed services seldom benefit from the experience.

Women are the fastest-growing sector of the prison population. Between 1980 and 1998 the number of women in state and federal prisons was 84,400 , representing an increase of over $500 \%$. Black women were more than eight times as likely to be in prison in 1997 as white women (Families Against Mandatory Minimums, 2002). Men continue to make up the majority of the prison population and both genders are being incarcerated at record levels.

A significant negative impact occurs when women and men are removed from and separated from their families and children. After release it is very difficult to reestablish relationships with their children and many children suffer emotionally, financially, and socially as result of their parents' incarceration. There have been relatively few studies that examine the impact of incarceration on prisoners' families. Research has found that the financial burden is severe and children often suffer trauma from separation and the stigma of incarceration. Often the parent-child relationship is beyond repair after a period of incarceration (Foster \& Hagan, 2007).

\section{A look at the numbers-Kentucky and the United States.}

In fiscal year 2000-2001, there were 10,754 people being held in 16 Kentucky correctional facilities. By 2002 that number had increased to nearly 
16,000 (Austin, Richards, \& Jones, 2003). These facilities represent minimum, medium and maximum security levels as well as women's institutions. In 2000$2001,4,604$ people were released on parole. That number increased to 4,909 in 2002 (Austin et al., 2003). Kentucky's crime and incarceration rates are below the national average, but still represent a major challenge for the state. The national recidivism rate is about $40 \%$ in the first three years after release. Kentucky's recidivism rate comes in just under that at $35 \%$ in the first three years. It is interesting to note that only $12 \%$ are returned to prison due to the commission of a new crime. Almost twice that amount, $23 \%$, are returned on technical violations such as missing appointments, noncompliance with ordered treatment or drinking alcohol. A quantitative portrait of those released from Kentucky's prisons will help to better understand the population. The majority of those released are white males under the age of $\mathbf{4 0}$ with a significant percentage having less than a high school diploma. Nearly $80 \%$ served time for a nonviolent crime with nearly $30 \%$ being incarcerated for drug offenses such as sale and possession. The average sentence length is 5 years, but there are many who received sentences of 4 years or less for a Class D offense (Austin et al., 2003a).

Nationally, the Bureau of Justice Statistics (BJS) reported that in 2002, 2,019,234 people were being held in the nation's jails and prisons (Prison and Jail Inmates at Midyear 2002, April 2003). Two-thirds of those people were being held in prisons run by the 50 states, the federal government, and the District of Columbia with the other one-third being held by local authorities. Alarmingly this figure does not include the over 100,000 minors under the age of 18 being held 
in juvenile facilities across the country. Nor does it include the 4 million on probation or the additional three-quarters of a million on parole. When combining all of these populations a staggering $6,627,322$ people in the United States who are under the supervision of the United States criminal justice system (Elsner, 2004). As discussed earlier, many of those who are incarcerated leave children and families in the community. Tables 1-3 show statistics gathered from the Survey of Inmates in State and Federal Correctional Facilities (Hairston, 2007).

The majority of both state and federal prisoners were parents, with approximately $60 \%$ in both settings reporting that they had dependent children. Children were more likely to be in the care of their mothers before her incarceration and men were more likely to report that their children were in the care of their mothers during their incarcerations (Hairston \& Oliver, 2007). The following table illustrates that the majority of mothers and nearly half of fathers lived in the same home as their children before going to prison (Hairston, 2007).

\section{Table 1}

\section{Family Status for State and Federal Prisons}

\begin{tabular}{|l|r|r|}
\hline Family Status & State & Federal \\
\hline $\begin{array}{l}\text { Percentage of prisoners who are parents of dependents } \\
\text { under the age of 18 }\end{array}$ & $55 \%$ & $63 \%$ \\
\hline Percentage of women who are parents & $65 \%$ & $59 \%$ \\
\hline Percentage of men who are parents & $55 \%$ & $63 \%$ \\
\hline Percentage of incarcerated parents who are married & $23 \%$ & $36 \%$ \\
\hline Percentage of parents who are divorced & $28 \%$ & $25 \%$ \\
\hline Percentage of incarcerated parents who were never married & $48 \%$ & $38 \%$ \\
\hline
\end{tabular}

The majority of mothers had at least one minor child living with them prior to their incarceration and $1 / 3$ were the sole caregivers for their children. A much 
smaller percentage of fathers were living with their children prior to incarceration and only $4 \%$ of both state and federal inmates were the sole caregivers for their children (Hairston, 2007).

\section{Table 2}

Living Arrangements for State and Federal Prisoners Prior to Incarceration

\begin{tabular}{|l|r|r|}
\hline Living Arrangement & \multicolumn{1}{|c|}{ State } & Federal \\
\hline $\begin{array}{l}\text { Percentage of mothers who had at least one minor child } \\
\text { living with them before incarceration }\end{array}$ & $64 \%$ & $84 \%$ \\
\hline $\begin{array}{l}\text { Percentage of mothers who lived as a single parent, with no } \\
\text { other adults in the household before incarceration }\end{array}$ & $31 \%$ & $35 \%$ \\
\hline $\begin{array}{l}\text { Percentage of mothers who lived with their children and } \\
\text { spouse prior to incarceration }\end{array}$ & $12 \%$ & $20 \%$ \\
\hline $\begin{array}{l}\text { Percentage of fathers who had at least one minor child living } \\
\text { with them before incarceration }\end{array}$ & $44 \%$ & $55 \%$ \\
\hline $\begin{array}{l}\text { Percentage of fathers who lived as a single parent, with no } \\
\text { other adults in the household before incarceration }\end{array}$ & $4 \%$ & $4 \%$ \\
\hline $\begin{array}{l}\text { Percentage of fathers who lived with their children and } \\
\text { spouse prior to incarceration }\end{array}$ & $19 \%$ & $30 \%$ \\
\hline
\end{tabular}

Overwhelmingly incarcerated fathers report that their children went into the care of their mother when they became incarcerated. Only $1 / 3$ of mothers reported the same about their children's fathers when they became incarcerated. In the case of incarcerated mothers, their children often go into the care of their grandparents or other relatives (Hairston \& Oliver, 2007). 


\section{Table 3}

Location of Children during a Parent's Incarceration

\begin{tabular}{|l|r|r|l|r|r|}
\hline $\begin{array}{l}\text { Incarcerated mothers } \\
\text { report their children } \\
\text { are living: }\end{array}$ & State & Federal & $\begin{array}{l}\text { Incarcerated fathers } \\
\text { report their children } \\
\text { are living: }\end{array}$ & State & Federal \\
\hline With fathers & $28 \%$ & $31 \%$ & With mothers & $90 \%$ & $92 \%$ \\
\hline In foster care & $10 \%$ & $3 \%$ & In foster care & $2 \%$ & $1 \%$ \\
\hline With grandparents & $53 \%$ & $45 \%$ & With grandparents & $13 \%$ & $10 \%$ \\
\hline With other relatives & $26 \%$ & $34 \%$ & With other relatives & $5 \%$ & $5 \%$ \\
\hline With friends or others & $10 \%$ & $12 \%$ & $\begin{array}{l}\text { With friends or } \\
\text { others }\end{array}$ & $4 \%$ & $6 \%$ \\
\hline
\end{tabular}

While the earlier statistics describing those who are imprisoned do alarm researchers, communities and policy makers, the later statistics describing the impact on children are alarmingly ignored by not only policy makers and government officials, but by social workers, teachers, and other helping professionals as well.

\section{Prisoner reentry.}

Austin, Richards and Jones (2002) reported that the return of prisoners is concentrated in certain communities. These are the same communities that struggle with high crime rates and high incarceration rates. Of those in prison in 2001, 64\% were Caucasian, 35\% African American and 1\% Hispanic (www.cor.state.ky.us, February 10, 2003). In 1998, 61\% of those released from prison were Caucasian and $38 \%$ were African American. Communities that already have inadequate resources and high crime rates are further burdened by people returning home who have complex, and often misunderstood, needs and issues. The transition from prison to home is often filled with profound trauma and confusion. 
Serving long sentences (five years or longer) often creates deterioration and disorganization that many overlook or do not realize. Many of those who have been in prison have become used to the prison regime and their abilities to make their own decisions, plan for life, or provide for themselves may be significantly impaired. Persons released from prison face a unique set of challenges and many do not know how they will survive the transition without knowing where they will go, where they will live and work (Austin, Richards, \& Jones, 2003).

The overarching goal of reentry is to return individuals to the broader society who have discharged their legal obligation to society by serving their sentences and demonstrating that they can live by society's rules (Travis, 2002). Therefore, the primary objective for both the offender and the criminal justice agency should be the prevention of recurring antisocial behaviors. This process should include the identification of those conditions that lead to relapse and the development of a plan to address them. A strategy of prevention rather than for punishment is required.

Despite the fact that there are nearly 600,000 inmates released on parole from state and federal prisons every year, there has been very little attention given to policy development for dealing with people after their release (Petersilia, 2000). Increased amounts of money are being spent on prisons each year, but not on rehabilitation. This means that fewer inmates leave prison having addressed their work, education, and substance abuse problems. It is reported that $70-85 \%$ of state prisoners need substance abuse treatment, but only $13 \%$ 
actually receive it while incarcerated. Nearly 1 in 5 inmates in U.S. prisons report having a mental illness (Solomon \& Draine, 1995). Whether these problems are addressed pre-release profoundly affect recidivism rates once offenders are released on parole.

The disillusionment of parole over the years reached such a point that many proposed that it simply be abolished. The Determinant Sentencing Law, enacted by California in 1976, abolished discretionary parole release.

Determinate sentencing means automatic release (Petersilia, 2001). Today, indeterminate sentencing and discretionary release have been replaced with determinate sentencing in states, although Walker (2001) proposed that changing or abolishing parole would not reduce serious crime. Parole experts have consistently asserted that the public is misinformed when it labels the parole system as lenient.

Actually, through their use of discretional release, parole boards can target more violent and dangerous offenders. With the abolishment of parole or the reduction of parole authorities' discretion, the controlled system of earned release for selected inmates is replaced with automatic release for nearly all inmates (Petersilia, 2001). Instead of an adversarial system focused on punishment, it should rather be one of restorative justice that "emphasizes dialogue, negotiation, and the reestablishment of a positive relationship between victim and offender" (Walker, 1998, p. 224). In other words, it may be more effective to build a healthy community than to support the dichotomy of the criminal vs. the law-abiding. 


\section{Scope of the Problem-Children with an Incarcerated Parent}

The removal of a parent through incarceration creates unique and individual challenges and stressors that often go unnoticed by others (La Vigne, et al., 2008). The stigma and shame associated with having an incarcerated parent may make it difficult for school personnel or social workers to identify the children with an incarcerated parent. Additionally, uncertainty and instability in the home may contribute to negative outcomes and behaviors such as poor academic achievement, behavioral problems, substance abuse or future criminal behaviors (La Vigne, et al., 2008; Miller, 2006; Moses, 1995; Travis, et al., 2003).

The U.S. Department of Justice estimated in 1999 that there were 721,500 parents in State and Federal prison, resulting in 1,498,800 children under the age of 18 having a parent in prison (Mumola, 2000). Later estimates place the number of children with an incarcerated parent closer to 2 million (La Vigne, et al., 2008; Tebo, 2006). The 1999 estimates represent an increase of over 500,000 children since 1991 and $2.1 \%$ of all minor children in the US (Mumola, 2000). Most of these children are low-income, young (under the age of 10), and come from minority groups as poor minority groups are disproportionately impacted by crime policies (La Vigne, et al., 2008; Mauer, 1999). African American children are 9 times and Latino children are 3 times more likely to have an incarcerated parent than white children (Mazza, 2002). This disproportion is due in large part to the high percentage of Black and Latino men and women being held in prison today, a percentage far greater than their percentage in the overall US population (13.5\% African American and 14.8\% Latino overall). Half 
of all prison inmates are African American and $17 \%$ are Hispanic. The impact of incarcerating such a high percentage of a population damages the communities beyond the impact of crime and it helps to ensure that future generations will struggle with poverty, drug use and crime (Mauer, 1999).

Children of incarcerated parents often show signs of distress caused by an instable home life and parental separation such as depression, aggression, truancy, and academic underachievement. Emotionally they often suffer with feelings of loss, fear, shame, anger, embarrassment and insecurity (Hagen \& Myers, 2003; Moses, 1995). Additionally, many of the children of incarcerated parents are often impacted by other environmental risk factors such as poverty, parental substance use, and parental mental illness. Examining incarceration as both a "marker of other risks and as a unique risk factor" is poorly documented in the literature (Dallaire, 2007).

\section{Characteristics of incarcerated parents.}

\section{Mothers.}

In the 1990's the number of women incarcerated in the United States increased by $106 \%$ and women now make up $7 \%$ of the total prison population. This growth is attributed largely to increasing drug offenses, increasing parole violations (primarily due to drug offenses), declining release rates and increasing sentence lengths (Hanlon, O'Grady, Bennett-Sears, \& Callaman, 2005). Over $75 \%$ of those women report having minor children and they are considerably more likely than incarcerated fathers to have been living with their children prior to their incarcerations (Tuerk \& Loper, 2006). Unlike the $90 \%$ of incarcerated 
fathers who report that their children are in the care of their mothers during their periods of incarceration, incarcerated mothers only report that $28 \%$ of their children are cared for by their fathers. The majority of children with incarcerated mothers are cared for by relatives such as grandparents $(53 \%)$ or other relatives (26\%). Another $10 \%$ of those children are placed in foster care during their mothers' incarcerations (Moses, 2006a, 2006b; Tuerk \& Loper, 2006).

Most incarcerated mothers are single, uneducated and poor and many have committed their crimes to support their drug habits (Covington, 2003). All of these factors are associated with an increased risk of developmental issues in young children such as an inability to trust others, difficulty with appropriate attachments and trouble empathizing with others (Gabel \& Johnston, 1995; Greenberg, 2006; Mather \& Adams, 2006). Additionally, many incarcerated mothers have high rates of substance use and mental illness, both of which have been shown to negatively impact child outcomes later in life (Poehlmann, 2005). Many come from poor urban environments where they were raised by single mothers themselves or in foster homes.

Incarcerated mothers are often portrayed, and thought of, as incompetent mothers who are neglectful of, or ambivalent to, the needs of their children. In actuality, separation from their children and concern for their welfare are some of the most difficult challenges that mothers face while incarcerated and is worsened by the limited contact that many mothers have with their children during their imprisonment. Maintaining those parental ties between mothers and 
their children helps both cope with and survive a very stressful event in both of their lives (Covington, 2003; Moses, 1995).

\section{Fathers.}

It is estimated that half of the men imprisoned in the United States are fathers to minor children (Kinner, Alati, Najman, \& Williams, 2007). Many of these men were not the primary caregivers for their children prior to their incarcerations and most of their children are in the care of their mothers during their incarcerations. Due to this, the impact of fathers' incarcerations on the children left behind is often underestimated. Much of the available research focuses on the impact of maternal incarceration, but the incarceration of America's fathers has severe and negative consequences for children as well (Roy \& Dyson, 2005).

The majority of incarcerated fathers $(93 \%)$ will eventually be released and return to their communities and families. Of the approximate 600,000 men who are released from prison each year many will attempt to reconnect with spouses, partners, and children, although many of these efforts to reconnect will be unsuccessful (Dyer, 2005). Fathers are more likely to emotionally retreat from their children as a way of dealing with the pain of separation and many fathers, although not living with their children, were contributing to their care financially prior to their incarceration. This loss of income often causes significant financial stressors for the family (Roy \& Dyson, 2005) and may further throw families into poverty. 
The likelihood of fathers' imprisonment differs dramatically by race and ethnicity. Incarceration has become so prevalent among minority groups that it has become an expected part of life in many communities. Children of color are also more likely to live in poverty and in neighborhoods characterized by crime and drug use. When adding these risk factors to the experience of parental incarceration children of color are at high risk of negative outcomes (Dallaire, 2007; Swisher \& Waller, 2008).

\section{Role of Other Risk Factors}

Other risk factors in children's lives also play pivotal roles in determining their successes as children, including poverty, parental substance use, and parental mental illness. Much of the existing literature fails to distinguish the risk posed by traumatic and stressful circumstances from those posed by losing a parent to incarceration. It is often difficult to have the precision required to accurately evaluate the impact of these risk factors independently from other factors. This is due largely to the types of available data and a lack of longitudinal data. Additionally, many child outcomes have been linked to multiple factors, that often exist in tandem, in children's lives and determining the impact of any one factor by itself is difficult and complex (Travis \& Ward, 2003). Many of the children of incarcerated parents are also children of poverty, the children of parents with mental illnesses, and the children of parents who use/misuse substances. Having a parent incarcerated may be only the most recent thing to happen to these children. When trying to determine the impact of existing risk factors it is important to determine whether any one risk factor places a child at 
greater risk or if, in fact, it is the combination of risk that creates the perfect storm resulting in negative child outcomes including criminality and addiction.

\section{Poverty.}

The negative outcomes that children living in poverty face are well documented in the literature (Betson \& Michael, 1997; Corcoran \& Chaudry, 1997; Lewit, Terman, \& Behrman, 1997; Mather \& Adams, 2006; Mather \& Rivers, 2006). Their access to medical care, nutrition, high quality education, and proper housing are severely limited. The child poverty rate has become one of the most widely used indicators of child well-being, in part because of the strong relationship between poverty and children's development (Mather \& Adams, 2006). Children living in poverty are more likely to be members of minority groups (especially African American), and live in single parent homes with a parents who are undereducated and often unemployed. As discussed earlier, disentangling these causes of child outcomes is no easy task (Mather \& Rivers, 2006).

\section{Parental substance use.}

Children with a parent in prison are much more likely to have a parent who uses substances as a large percentage of incarcerated parents, especially mothers, are incarcerated for drug crimes. One in three mothers in state prison committed their crimes to support drug habits, either to get drugs or to get money for drugs (Mumola, 2000). Of adult problem drug users, nearly $30 \%$ of women and $18 \%$ of men live with children (Cooke, Kelley, Fals-Stewart, \& Golden, 2004). Children who live with substance using parents are also more likely to live in 
poverty and to have a parent suffering from a psychiatric disorder such as depression or antisocial personality disorder (Cooke et al., 2004). Many times this drug use has been going on for years prior to a parent's incarceration and has already had a profound effect on the development of the children in their care (Smith, Krisman, Strozier, \& Marley, 2004b).

\section{Parental mental illness.}

Almost one-third of women and another one-third of men in the United States have diagnosable mental illnesses and they are at least as likely as those without mental illnesses to parent at least one child. Research suggests that these children are at a high risk of developing their own mental illnesses and are at risk for other negative outcomes (Mowbray \& Mowbray, 2006), including developmental delays, lower academic achievement and difficulty in developing and maintaining social relationships. Difficult home environments characterized by low family cohesion, poor communication, chaos, and parent-child discord are often found when there is a mentally ill parent (SAMSHA).

\section{Significance of the Study}

Children with incarcerated parents constitute a growing population within our communities -an estimated 2 million children with a parent currently incarcerated and that number does not include children whose parents have been previously incarcerated and released or those whose parents are under some kind of community supervision such as probation or parole (La Vigne, et al., 2008). Researchers have documented the negative outcomes that many of these children face, including future substance use, academic 
underachievement, poverty, and future criminality (Dallaire, 2007; Poehlmann, Shlafer, Maes, \& Hanneman, 2008; Travis, et al., 2003). It would be difficult to argue that the incarceration of a parent does not have a profound impact on those children left behind; however, there is limited research in the literature that parses out those effects of parental incarceration from other traumatic and stressful circumstances that also generally characterize the lives of these children (Travis \& Ward, 2003).

Past studies have focused on the impact of incarcerating parents, but are often unable to establish parental incarceration as both an indicator of others risks and as a unique risk factor (Dallaire, 2007). This study proposes a comparison between matched samples of at-risk children, some of whom experience parental incarceration and some who do not. Data collected by the Children at Risk program in five communities (Austin, TX; Bridgeport, CT; Memphis, TN; Seattle, WA and Savanna, GA) and publically available through the Inter-University Consortium for Political and Social Research (ICPSR) consists of baseline and follow up data for children identified to be at risk due to residing in neighborhoods characterized by poverty, delinquency, drug problems, and crime (Harrell, Cavanagh, \& Sridharan, 1998). The aim of the current study is to examine the outcomes for at-risk children who experience parental incarceration compared to those who do not and determine whether documented negative outcomes are more or less likely to be due to parental incarceration in the presence of other personal and environmental risk factors such as poverty, parental substance use and mental illness. The current study seeks to examine 
the relationship between phenomena (variable centered) and will not look at the differences between subgroups that exist within the sample (person centered).

\section{Research Questions and Hypotheses}

To address the gaps in the existing literature this dissertation will pose a multiple risk model and examine the interactions of risk and their impact on child outcomes. Risk factors are identified as having a parent incarcerated, living in poverty, experiencing parental mental illness, and parental substance use. Two primary research questions were addressed.

\section{Research question 1: To what degree do parental risk factors influence} child outcomes?

Hypothesis 1: The presence of multiple parental risk factors will increase the likelihood that children experience negative child outcomes.

Research Question 2: Are child outcomes more significantly linked to any one parental risk factor over another?

Hypothesis 2: Specific child outcomes are more significantly linked to specific risk factors.

\section{Plans for the Chapters}

Chapter 1 has provided an overview of the problem and the complexity of the interplay between multiple risk factors that contribute to negative child outcomes as well as the significance and purpose of the study. Chapter II provides a review of relevant literature and an exploration of theories applicable to the risk factors that children of incarcerated parents face, and will introduce a multiple risk model. Chapter III will discuss the research design and methods, 
with the results of the research presented in Chapter IV. Finally, Chapter V will be a discussion of the study findings, implications for practice and policy development and recommendations for risk assessment and action. 


\section{CHAPTER ॥ \\ LITERATURE REVIEW}

The prison, the darkest region in the apparatus of justice, it is the place where the power to punish, which no longer dares to manifest itself openly, silently...functions.

Michel Foucault, Discipline and Punish

If a child's life is likened to a tree and different people are asked to examine a separate part of the tree they all might give you a very different picture of what that tree is like. If touching the trunk it might be described as wide, strong, rough to the touch. The leaves may illicit images of fragility, something that is easily destroyed, but full of life and color. The branches may be described as flexible, able to withstand strong force winds. Still yet, the soil that the tree stands in and from which it draws nutrients may be described as moist, easily crumbled, and rich. Any one of those descriptions is correct and yet it does not present an accurate picture of the tree as a whole. A child's life, similarly, must be examined as multiple parts coming together to create a whole and all of those separate parts add something to how a single child will progress through life. When examining the impact of parental incarceration on child outcomes it is 
necessary to examine multiple risk factors that influence child outcomes (Johnson \& Waldfogel, 2004; Johnson, 2009)

The ever increasing prison population is poorly understood insofar as the consequences of increasing parental incarceration on children, families, and communities. Many children who lose their parents to incarceration have increased aggression and other behavioral problems (Johnston, 1995; Mazza, 2002), increased mental health issues, such as depression (Kampfner, 1995; Poehlmann, 2005), as well as an increased risk for future criminality (Miller, 2006) and substance abuse (Bilchik, Seymour, \& Kreisher, 2001). While having an incarcerated parent creates a unique set of risks it is important to also consider the impact of multiple, pre-incarceration, risk factors. Multiple studies have examined the impact of incarceration on families (PoehImann, 2005; Wakefield, 2007), but most existing studies have not been able to separate the causal effects of incarceration from the effects of other risk factors that were already present in a child's life. These risk factors include parental substance use, parental mental illness, and poverty. For many children these factors had already placed them at an increased risk of negative outcomes long before their parents were incarcerated (Johnson \& Waldfogel, 2004). For example, the incarceration of mothers contributes to negative outcomes, but most women are incarcerated due to a drug related crime (parental substance use) and often live in poverty prior to their incarceration (Johnson, 2009). Additionally, incarcerated fathers are more likely to be members of minority groups and also lived in poverty prior to incarceration (Waller \& Swisher, 2006). Additionally, parental 
incarceration has a unique set of risk factors which include the trauma of separation, shame and stigma, depleted resources when a parent goes to jail/prison, and possible genetic predisposition to criminality (Johnson, 2009).

The hope for this chapter is that the reader will have a broad understanding of who is in prison in the United States and the literature related to four risk factors that impact the outcomes of children: parental incarceration, parental substance abuse, parental mental illness, and poverty. This discussion illustrates that many risk factors occur in conjunction with another and that most risk factors lead to similar outcomes. Hundreds of studies, books, and reports have examined the detrimental effects of each of these risk factors and drawing the essential information from a vast array of literature is challenging.

\section{Pathways for Risk}

No garden is without its weeds. - Thomas Fuller

Every childhood is riddled with risk, every life in fact. Risks are the weeds in our gardens that we always work to avoid and diminish. Children, however, have a decreased capacity to protect themselves from risk and therefore rely heavily on the people around them for protection. It cannot be argued that parents don't want to protect their kids, but there are some risks that parents, too, are powerless against. Some weeds that threaten to overgrow the garden and leave it in chaos and disarray.

It is estimated that as many as 2 million children have a parent in prison (La Vigne, et al., 2008) and 12.7 million children live in poverty across the nation (NCCP), and $50 \%$ of seriously mentally ill adults are thought to be parents. Each 
of these factors contributes to risk, but it is unclear how risk is compounded from multiple factors or how many children actually fall within multiple risk groups.

Sigmund Freud, Erik Erikson, and Jean Piaget posited that the successful completion of developmental tasks during childhood are crucial to adult mental health (Lesner \& Hillman, 1983). More recent researchers attest that adverse childhood events affect functioning throughout life (Callahan \& Hilsenroth, 2005; Massie \& Szajnberg, 2006). Adverse childhood events found to affect child outcomes range from abuses to household dysfunction, childhood trauma, parental mental health and substance use, and to the incarceration of a parent (Chapman, Dube, \& Anda, 2007).

The pathways of risk are multi-faceted, overlapping, and reoccurring (Greenberg, Lengua, Coie, \& Pinderhughes, 1999; Sameroff, Seifer, Barocas, Zax, \& Greenspan, 1987; Williams, Anderson, McGee, \& Silva, 1990). Risk factors are not linear and do not occur independently of each other. Rather, they often occur simultaneously and the complexity of risk makes it extremely difficult to tease out the effects of any one risk factor. Additionally, the effects of risk vary greatly and depend on child and family strengths, support systems, services available and the specific combination of risk factors that are as unique as every child and family across this country (Johnson \& Waldfogel, 2004; Johnson, 2009).

\section{A Multiple Risk Model}

Models of development often place human development within a complex system of interactions between individuals and their environments. A 
transactional model, however, takes the process of development one step further and asserts that development occurs when there are continuous and dynamic interactions occurring between children and the social contexts in which they are immersed (Sameroff, Bartko, Baldwin, Baldwin, \& Seifer, 1998). In all models the effects of individual and environmental factors are important. Those factors that adversely affect development are risk factors; while those that promote development or protect against adversity are protective factors (Johnson \& Waldfogel, 2004).

Multiple risk models take into account the effects of various risks within children's lives and the environments that impact their overall development. The greater the number of risk factors in a child's life, the more likely that child is to face adversity or experience negative effects developmentally. Researchers have explored the concept of multiple risk and have determined that there is a relationship between the number of parental and ecological risk factors in a child's life and child outcomes such as cognitive performance (Sameroff et al., 1998), social competence (Furstenberg, Cook, Eccles, Elder, \& Sameroff, 1999), and behavioral disorders (Williams, Anderson, McGree, \& Silva, 1990).

Furstenberg (1999) conducted a longitudinal study of adolescents in five different Philadelphia neighborhoods. The families were divided into low and high risk groups based on the number of risk factors in each family. Risk of negative outcomes (mental health and academic performance) increased from $3 \%$ to $50 \%$ when the low and high risk groups were compared. For problem behaviors the risk increased from $3 \%$ to $45 \%$, indicating that the impact of 
multiple risks could be correlated with increased mental health issues and decreased academic performance.

Another study examined behavioral and emotional disorders in preadolescent children similarly found that multiple risk factors distinguished children with behavioral disorders from those without (Williams et al., 1990). Williams, et al. (1990) found that only $7 \%$ of children with 2 risk factors had behavioral problems compared to $40 \%$ of those with 8 or more. Risk factors examined included single parenthood, poverty, maternal mental health and young motherhood.

In the current study a model of multiple risks is being tested to determine whether parental incarceration or the risks that exist before a period of parental incarceration, or outside of parental incarceration, contribute more significantly to negative child outcomes. The pre-parental incarceration risks addressed by the model include poverty, parental mental illness, and parental substance use.

The multiple risk model is designed to move throughout a child's life. The model begins with the inherent risks when children are products of high risk pregnancies or high risk births. As children progresses through life, symbolized by the arrow pointing right in Figure 1, they can be impacted by other life variables that are of interest in this research: poverty, parental mental illness, and parental substance use. They are placed within the same box in the model because they are believed to occur at the same time and often in tandem with one another. Many of these risks are present in children's lives before parents are ever arrested or imprisoned. Once a parent is incarcerated a unique set of 
risk factors is introduced to the child that may further impact child outcomes. It is important to note that although the model appears to be linear, the risk factors presented do not often occur in a linear fashion in a child's life. Many times they all occur at once, or they are present and addressed, then return later in a child's life. The model is presented in four sections to better illustrate the cumulative effect of the risk factors being discussed and addressed by the study.

\section{PRIOR TO INCARCERATION}

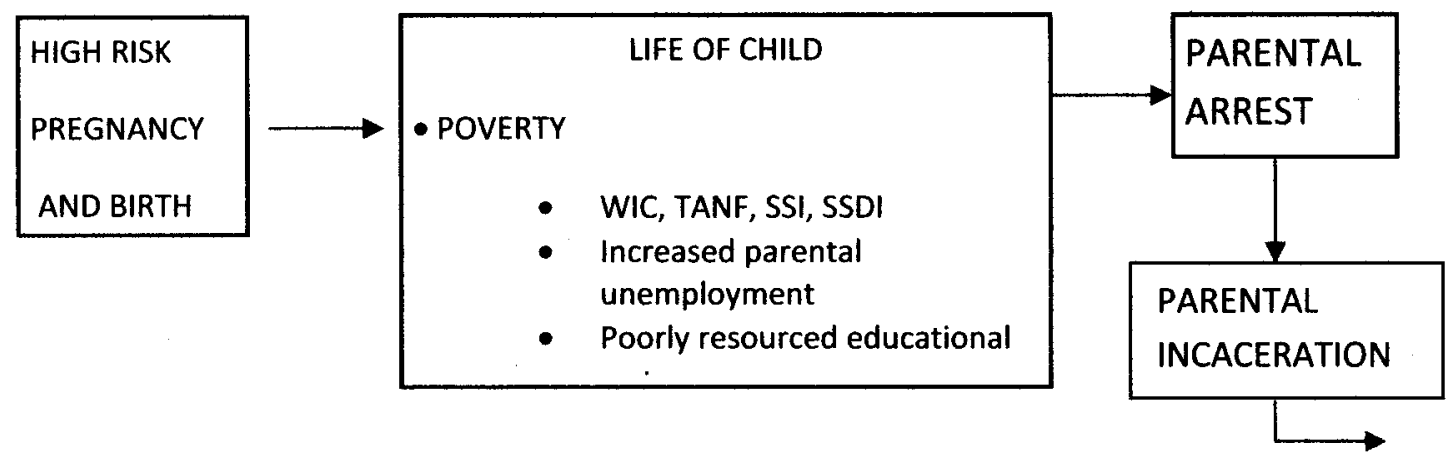

Figure 1. A Multiple Risk Model: poverty, parental mental illness, parental substance use, and parental incarceration.

\section{Poverty and negative child outcomes.}

If a photograph of all Americans who live below the poverty line could be captured the picture today would look much different than the picture of three decades ago. More people would be crowded into the photo, but perhaps most notably would be who is in the picture. Fewer sick, elderly, or infirmed persons would be there due to the successful policies of the 1990's that targeted elderly poverty. Instead of impoverished old people we would see impoverished children (Corcoran \& Chaudry, 1997). It is estimated that 1 in 5 American children, approximately 12 to 14 million, live in households that fail to exceed the poverty 
threshold. An additional one-fifth of children live in households that make no more than twice the federal poverty level. The impact of poverty can be profound in the lives of these children by creating pathways for risk that include inadequate nutrition, fewer learning experiences, instability of residence, environmental toxins, and homelessness (Brooks-Gunn \& Duncan, 1997).

These children do not reflect a random cross section of all children as poverty in the US is unevenly shared by children from racial and ethnic minorities, children from large families or from families with single parents, and whose parents did not receive GEDs or high school diplomas (Corcoran \& Chaudry, 1997). In $1992,46 \%$ of African-American children and $40 \%$ of Latino children lived in poverty, compared to only $16 \%$ of Caucasian children (Sawhill, 1988). In 2007, the federal poverty line for a family of four was set at $\$ 21,200$ (Cauthen \& Fass, 2008). The current poverty measure was established in the 1960s, and other than updates for inflation, it has remained unchanged for the last 40 years. The measure was based on assumptions of family expenditures, specifically how much the family was expected to spend on food each month. The original measure assumed that families spent one-third of their income on food each month, but, in actuality, today food comprises only one-seventh of a family's expenses, while costs for housing, health care, transportation, and child care have risen disproportionately (Cauthen \& Fass, 2008). This figure is important to understand as it is the rule of thumb used by most federal and private aid agencies to determine eligibility. 
Many families make more than the poverty guideline allows and yet do not make enough to meet the daily living needs their families. Outdated measures of poverty are largely to blame for the working poor in the United States who make too much to qualify for aid, but not enough to pay for living expenses, health care needs, child care needs, and food for the family. Additionally, gross income is counted rather than net income which inflates the amount of money actually available to families (Lewit, et al., 1997).

The statistics of poverty conceal an important point-children experience poverty in different ways and for different periods of time. The duration of poverty changes drastically from one child to the next and researchers have explored the differences in long term poverty among America's children (Bane \& Ellwood, 1986; Duncan, Brooks-Gunn, \& Klebanov, 1994; Duncan \& Rodgers, 1987; Hill, 1983). This point is illustrated by a large longitudinal study that followed 1,000 children and their economic circumstances and found that twothirds of the children spent less than five years in poverty, while the other onethird spent one year or less in poverty. A small percentage, however, $5 \%$ of all children and $15 \%$ of children who ever became poor remained in poverty for 10 years or more (Duncan \& Rodgers, 1988). Long-term poverty was extremely rare among white children, but African-American children in long term poverty represented $29 \%$ of those poor for 10 years or more, and almost half of those poor for 5 years (Duncan \& Rodgers, 1988). Table 4 illustrates the persistence of poverty from childhood through early adulthood (Corcoran, 1995; Corcoran \& Chaudry, 1997). 
Two important points are illustrated by Table 4. First, long term childhood poverty significantly increases the likelihood of poverty in adulthood and second, regardless of poverty status in childhood, African-American children are more likely to be poor as adults than whites (Corcoran \& Chaudry, 1997).

\section{Table 4}

Persistence of Poverty from Childhood Through Early Adulthood

\begin{tabular}{|c|c|c|c|}
\hline \multirow[t]{2}{*}{$\begin{array}{l}\text { Race and Poverty Status } \\
\text { During Childhood }\end{array}$} & \multicolumn{3}{|c|}{$\begin{array}{c}\text { Percentages of Adults Ages } 27 \text { to } 35 \text { Who } \\
\text { Were }\end{array}$} \\
\hline & $\begin{array}{l}\text { Never } \\
\text { Poor }\end{array}$ & $\begin{array}{l}\text { Poor } 1 \% \text { to } \\
50 \% \text { of Early } \\
\text { Adult Years }\end{array}$ & $\begin{array}{l}\text { Poor } 51 \% \text { to } \\
100 \% \text { of } \\
\text { Early Adult } \\
\text { Years }\end{array}$ \\
\hline $\begin{array}{l}\text { Black } \\
\text { Never poor } \\
\text { Poor } 1 \% \text { to } 50 \% \text { of childhood yrs } \\
\text { Poor } 51 \% \text { to } 100 \% \text { of childhood yrs }\end{array}$ & $\begin{array}{l}74 \\
63 \\
54\end{array}$ & $\begin{array}{l}18 \\
17 \\
20\end{array}$ & $\begin{array}{c}8 \\
20 \\
26\end{array}$ \\
\hline $\begin{array}{l}\text { White } \\
\text { Never poor } \\
\text { Poor } 1 \% \text { to } 50 \% \text { of childhood yrs } \\
\text { Poor } 51 \% \text { to } 100 \% \text { of childhood yrs }\end{array}$ & $\begin{array}{l}90 \\
78 \\
76\end{array}$ & $\begin{array}{c}9 \\
19 \\
14\end{array}$ & $\begin{array}{c}1 \\
4 \\
10\end{array}$ \\
\hline
\end{tabular}

(Mary E Corcoran \& Chaudry, 1997)

Poor children suffer higher incidences of developmental problems, adverse health conditions, and other negative outcomes than non-poor children. Specific outcome areas that are negatively impacted include physical health, cognitive ability, school achievement, and emotional and behavioral outcomes (Brooks-Gunn \& Duncan, 1997).

Children in poverty display higher rates of emotional and behavioral problems that can be grouped into two main categories, externalizing behaviors (fighting, aggression) and internalizing behaviors (depression, anxiety, social 
withdrawal) (Johnson \& Waldfogel, 2004; Johnson, 2009; Korenman, Miller, \& Sjaastad, 1995; McLeod \& Shanahan, 1993). McLeod and Shanahan (1993) found that the percentage of years that a child spent in poverty was positively related to internalizing emotional symptoms, even after current poverty level, mother's education level and other risk factors were controlled for.

Understanding poverty as a risk factor for negative child outcomes is critical when examining the total risk that children face throughout their lives. Table 5 illustrates many of those risks (Brooks-Gunn \& Duncan, 1997). 
Table 5

Selected Population-Based Indicators of Well-Being for Poor and Nonpoor

Children in the United States

\begin{tabular}{|c|c|c|c|}
\hline Indicator & $\begin{array}{l}\text { Percentage } \\
\text { of Poor } \\
\text { Children }\end{array}$ & $\begin{array}{l}\text { Percentage of } \\
\text { Nonpoor } \\
\text { Children }\end{array}$ & $\begin{array}{l}\text { Ratio of } \\
\text { Poor to } \\
\text { Nonpoor } \\
\text { Children }\end{array}$ \\
\hline \multicolumn{4}{|l|}{$\begin{array}{l}\text { Physical Health Outcomes (for } \\
\text { children between } 0 \text { and } 17 \text { years } \\
\text { unless noted) }\end{array}$} \\
\hline $\begin{array}{l}\text { Reported to be in excellent health } \\
\text { Reported to be in fair to poor } \\
\text { health }\end{array}$ & $\begin{array}{l}37.4 \\
11.7\end{array}$ & $\begin{array}{c}55.2 \\
6.5\end{array}$ & $\begin{array}{l}0.7 \\
1.8\end{array}$ \\
\hline $\begin{array}{l}\text { Experienced an accident, } \\
\text { poisoning, or injury in the past year } \\
\text { that required medical attention }\end{array}$ & 11.8 & 14.7 & 0.8 \\
\hline Chronic asthma & 4.4 & 4.3 & 1.0 \\
\hline $\begin{array}{l}\text { Low birth weight (less than } 2,500 \\
\text { grams) }\end{array}$ & 1.0 & 0.6 & 1.7 \\
\hline Lead poisoning & 16.3 & 4.7 & 3.5 \\
\hline $\begin{array}{l}\text { Infant mortality } \\
\text { Deaths during childhood (0 to } 14 \text { ) } \\
\text { Stunting (being in the fifth } \\
\text { percentile for height for age } 2 \text { to } 17\end{array}$ & $\begin{array}{c}1.4 \text { deaths per } \\
100 \text { live births } \\
1.2 \\
10.0\end{array}$ & $\begin{array}{c}0.8 \text { deaths per } 100 \\
\text { live births } \\
0.8 \\
5.0\end{array}$ & $\begin{array}{c}1.7 \text { deaths per } \\
100 \text { live births } \\
1.5 \\
2.0\end{array}$ \\
\hline $\begin{array}{l}\text { Number of days spent in bed in } \\
\text { past year }\end{array}$ & 5.3 days & 3.8 days & 1.4 days \\
\hline $\begin{array}{l}\text { Number of short-stay hospital } \\
\text { episodes in past year per } 1,000 \\
\text { children }\end{array}$ & 81.3 days & 41.2 days & 2.0 days \\
\hline \multicolumn{4}{|l|}{ Cognitive Outcomes } \\
\hline $\begin{array}{l}\text { Developmental delay } \\
\text { Learning disability }\end{array}$ & $\begin{array}{l}5.0 \\
8.3\end{array}$ & $\begin{array}{l}3.8 \\
6.1\end{array}$ & $\begin{array}{l}1.3 \\
1.4\end{array}$ \\
\hline \multicolumn{4}{|l|}{$\begin{array}{l}\text { School Achievement Outcomes (5 } \\
\text { to } 17 \text { vrs) }\end{array}$} \\
\hline Grade repetition & 28.8 & 14.1 & 2.0 \\
\hline $\begin{array}{l}\text { Ever expelled or suspended } \\
\text { High school dropout }\end{array}$ & $\begin{array}{l}11.9 \\
21.0\end{array}$ & $\begin{array}{l}6.1 \\
9.6\end{array}$ & $\begin{array}{l}2.0 \\
2.2\end{array}$ \\
\hline \multicolumn{4}{|l|}{ Emotional and Behavioral } \\
\hline $\begin{array}{l}\text { Parent reports child has ever had } \\
\text { an emotional or behavioral problem } \\
\text { that lasted } 3 \text { months or more. }\end{array}$ & 16.4 & 12.7 & 1.3 \\
\hline $\begin{array}{l}\text { Parent reports child ever being } \\
\text { treated for an emotional problem or } \\
\text { behavioral problem. }\end{array}$ & 2.5 & 4.5 & 0.6 \\
\hline $\begin{array}{l}\text { Parent reports child has } \\
\text { experienced one or more of a list of } \\
\text { typical child behavioral problems in } \\
\text { the last } 3 \text { months. }\end{array}$ & 57.4 & 57.3 & 1.0 \\
\hline
\end{tabular}


(Brooks-Gunn \& Duncan, 1997)

Research suggests that violence among poor families is more frequent and often more violent. This is attributed, partly, to economic stressors, the stress of racism among poor families of color, and an increased likelihood that women and mothers become poor when they leave abusive or violent relationships (Brandwein, 2007). Browne and Bassuk (1997) found that $60 \%$ of the homeless and poorly housed women surveyed had experienced severe abuse by their partners. Limited resources make it very difficult for women and their children to escape abusive or violent relationships. Often families flee and stay with friends or family members, but many times those trying to help are poor themselves and women are forced to return to unsafe environments. Additionally, poverty makes it very difficult for women to get the money to take their children and leave in the first place. There is not money for hotel/motel stays, flights, or even gas. A lack of affordable, permanent housing increases the risk that families will have no choice but to return to and tolerate abusive situations (Brandwein, 2007).

In conclusion, the research reviewed in this section illustrates the difficulties faced by children and families living in poverty. Risks from poverty include inadequate nutrition or medical care, an inability to access needed resources due to barriers such as income, transportation, and childcare needs, and families are often forced to remain in domestic violence situations due to similar barriers. In the next section, the multiple risk model is expanded to include risks from substance using parents. 
As discussed earlier, it is the combination of risks that places children at the highest likelihood of developing negative behaviors or outcomes. The multiple risk model being tested is expanded to include parental substance use in order to examine the combined impact of risk on child outcomes (Figure 2). Researchers have shown that substance use is relatively high among families living in poverty (Moe et al., 2007) and among those families facing other risk factors such as parental mental illness (Finkelstein, et al., 2005) and incarceration (Johnson, 2009).

\section{PRIOR TO INCARCERATION}

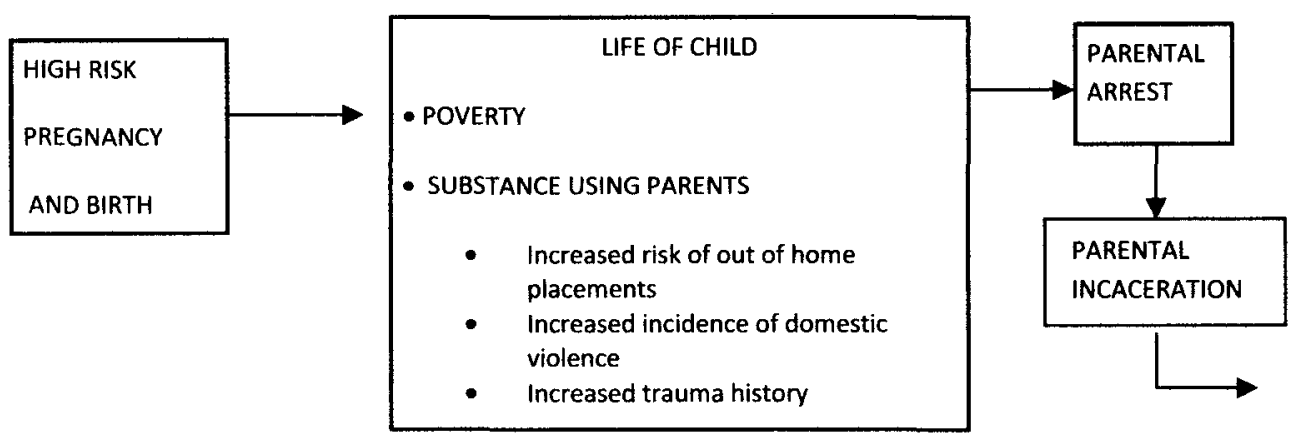

Figure 2. A Multiple Risk Model—poverty, parental substance use, parental mental illness, and parental incarceration.

\section{Parental substance use and negative child outcomes.}

Families affected by substance use have been extensively studied by clinicians and researchers. Many of these studies show a broad array of differences between children raised by parents who use substances and parents who do not. Children of substance using parents are at risk for behavioral, emotional and physical problems (Anda, et al., 2002; Casas-Gil \& NavarroGuzman, 2002; Knop, et al., 2002; Moe, et al., 2007). 
The 1992 National Longitudinal Alcohol Epidemiological Survey is the most recent estimate of the number of children living in homes with adults who use alcohol. It is estimated that $9,667,473$ children live in homes where one or more adults were classified in the last year to have a diagnosis of alcohol abuse or dependence. A staggering $28,046,258$ children were estimated to live in a home with one or more adult who carried a lifetime diagnosis of alcohol abuse or dependence (Grant, 2000). These numbers do not include children living with parents who use illicit drugs.

Children exposed to parental substance use exhibit a myriad of problems at a higher rate than those who are not. These behaviors include poor developmental outcomes, behavioral problems, and delinquency. They are also at an increased risk to use substances themselves and are more likely to experience physical and sexual abuse and neglect (Finkelstein, et al., 2005).

Children whose parents use alcohol or drugs are shown to be higher risk of attachment difficulties, of experiencing abuse and neglect, poor emotional and behavioral development and outcomes, as well as poor health outcomes and poverty (Osborne \& Berger, 2009). A possible explanation for this is that substance use can lead to reduced parental psychological functioning and parenting competence, which may adversely affect children (Osborne \& Berger, 2009).

Substance use is often implicated in child abuse and neglect, with approximately $40-80 \%$ of families involved with the child protection system having alcohol and/or drug use problems. Additionally, children whose parents 
use substances are three times more likely to suffer neglect and four times more likely to be abused than children whose parents do not use substances (Johnson \& Waldfogel, 2004). Studies that look at the link between parental alcohol use and adolescent alcohol use indicate a strong link between the two (Chassin, Curran, Hussong, \& Colder, 1996; Colder, Chassin, Stice, \& Curran, 1997).

Colder, et al. (1997) examined the impact of paternal and maternal alcoholism on children of alcoholics and found that the children escalated in their heavy drinking more rapidly than children whose parents did not use alcohol. This rapid escalation may reflect an early manifestation of, and risk for, problem drinking and alcohol abuse in adolescence and adulthood.

In conclusion, parental substance use has been found to decrease a parent's ability to competently parent their children leading to behavioral/emotional problems as well as a significantly increased risk of child abuse and neglect. Additionally, researchers have shown that children of substance using parents are more likely to begin using substances themselves. To further explore the multiple risks that children face, the next section will address parental mental illness and its impact on child outcomes.

The multiple risk model being tested is expanded to include parental mental illness in order to examine the combined impact of risk on child outcomes (Figure 3). Researchers have established that mental illness is high among adults who use drugs and mental illness often causes families to be forced into poverty due to an inability to work (Gutjahr, 2007; Hinden, Biebel, Nicholson, \& Mehnert, 2005) 


\section{PRIOR TO INCARCERATION}

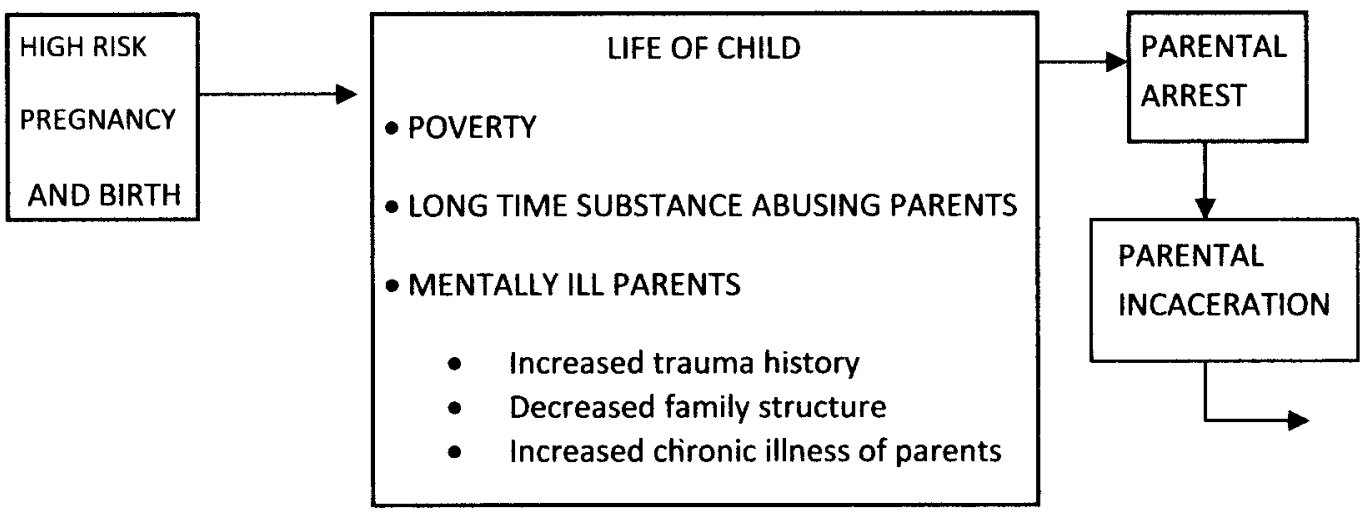

Figure 3. A Multiple Risk Model-poverty, parental substance use, parental mental illness, and parental incarceration.

\section{Parental mental illness and negative child outcomes.}

Parents with severe mental illness have been overlooked for several reasons. The first reason is related to the delivery system for mental health services. Prior to deinstitutionalization many individuals with mental illness lived in hospitals and other residential settings and were less likely to be parents. An unexpected consequence of the community mental health revolution is that more people struggling with mental illness are raising children. Research indicates that women with mental illness marry and have children at the same rate as other women, but have higher separation and divorce rates (Ackerson, 2003)

Craig (2004) stated that mothers with mental illness fall into two categories with the first category being comprised of those women who are mentally ill (i.e. depression, bipolar disorder, schizophrenia) and become parents. The second category is those women who become parents and then develop mental illnesses. Some mothers suffer an acute episode of mental illness, while others 
have chronic symptoms that impact their ability to parent their children for a period of years or for the entirety of a child's early years. All children who live with a parent suffering with mental illness are at risk, but those whose parent is chronically ill represent the highest level of ongoing risk.

Parents with a mental illnesses struggle to use appropriate discipline strategies with their children (Oyersman, Mowbray, Meares, \& Firminger, 2000), communication skills (Seeman, 1996), form appropriate attachments (Hill, 1996), and function at overall lower levels than parents without mental illnesses (Oyersman, et al., 2002). For example research has found that children with parents suffering from bipolar disorders were found to have learned at early ages to suppress their emotions, and their interactions with their children were often characterized by emotional unavailability, unresponsiveness, and criticism (Davenport, Zahn-Waxler, Adland, \& Mayfield, 1984). Downey and Coyne (1990) found that children of parents struggling with depression displayed higher rates of psychological problems and endured multiple parenting deficits from one or both parents.

Anthony (1973) likened having a parent with mental illness to mourning the death of a parent. Children often feel alienated or abandoned and variable moods and personality changes can make children feel as if their parents are strangers, someone unknown to them. Likewise, parents' withdrawn behaviors or unresponsiveness can lead to children feeling abandoned. As a result, the children of the mentally ill often struggle with negative feelings including anger, grief, guilt, shame, helplessness, and hopelessness (Anthony, 1973). Parents 
with mental illnesses often resort to less effective methods of parenting and indifferent, uninvolved and neglectful parenting can lead to aggression, low selfesteem, and poor self-control in their children (Gutjahr, 2007)

Due to the chronic nature of mental illness the risk of emotional, behavioral and psychological problems among the children of parents suffering from mental illnesses are likely to be cumulative. Additionally, mental illness can be episodic and many children can experience multiple episodes of acute symptoms from their parents (Oyersman, et al., 2000). The numerous episodes can interfere with, and interrupt, the parent's ability or willingness to build positive relationships with infants and children, therefore damaging their ability to appropriately attach. Problems that the children of the mentally ill experience appear to be related less to any specific diagnosis, but rather the functioning level of the parent. Low global functioning and low overt symptoms of parents increased the risk of depression and anxiety in their children (Gutjahr, 2007).

Beardslee, Versage, and Gladestone (1998) examined the impact of parental affective disorders on children. Parenting problems were identified as an important factor associated with negative child outcomes. Many times affective disorders made it very difficult for parents to raise their children in a nurturing and supportive manner because they were less responsive to their children and were more easily irritated by them. The parental interactions often lead to behavioral problems in the children, which only further exacerbate the irritation felt by the parent. Additionally, children whose parents suffer from affective disorders often struggle with strong emotions related to guilt and shame, 
have more interpersonal difficulties, and high levels of difficulty in overall functioning.

Many times the symptoms of chronic and persistent mental illness are so severe that gainful employment is impossible and many of those suffering from mental illness are forced to live below the poverty level and rely heavily on community resources to meet their needs and the needs of their families (Harpaz-Rotem, Rosenheck, \& Desai, 2006; Mowbray, et al., 2000; Oates, 1997). Stressors related to poverty, including family disruption and conflicts, marital discord, social isolation, social adversity, and financial stressors significantly impact children and make them vulnerable to impaired emotional responsiveness and a lack of attention to their own needs (Gutjahr, 2007).

Children of parents suffering from mental illnesses suffer from a range of cognitive, emotional and behavioral problems (Harpaz-Rotem, et al., 2006; Hinden, et al., 2005) more so than comparison groups of children. Often children deal with a great deal of anger, anxiety, sadness, grief, guilt, shame and helplessness (Anthony, 1973). They are often obsessed with fears of becoming ill, going crazy, or dying and many times have no healthy coping mechanisms and often turn to unhealthy mechanisms such as blocking their emotions and thoughts (Anthony, 1976).

In conclusion, the research reviewed in this section illustrates the difficulties that children with mentally ill parents face. Parents suffering from mental illness have more difficulty attending to the physical and emotional needs of their children. The children are often taught to use negative coping 
mechanisms, that do not serve them well in life, and their parents are often emotionally absent from their lives. Additionally, many families with mentally ill parents are forced to live in poverty due to an inability to work.

Parental incarceration will be examined as the final risk factor in the multiple risk model presented here (Figure 4). Researchers have established that parental incarceration is high among adults who use drugs, live in poverty, or suffer from mental illness (Johnson \& Waldfogel, 2004; Johnson, 2009; La Vigne, Naser, Brooks, \& Castro, 2005).

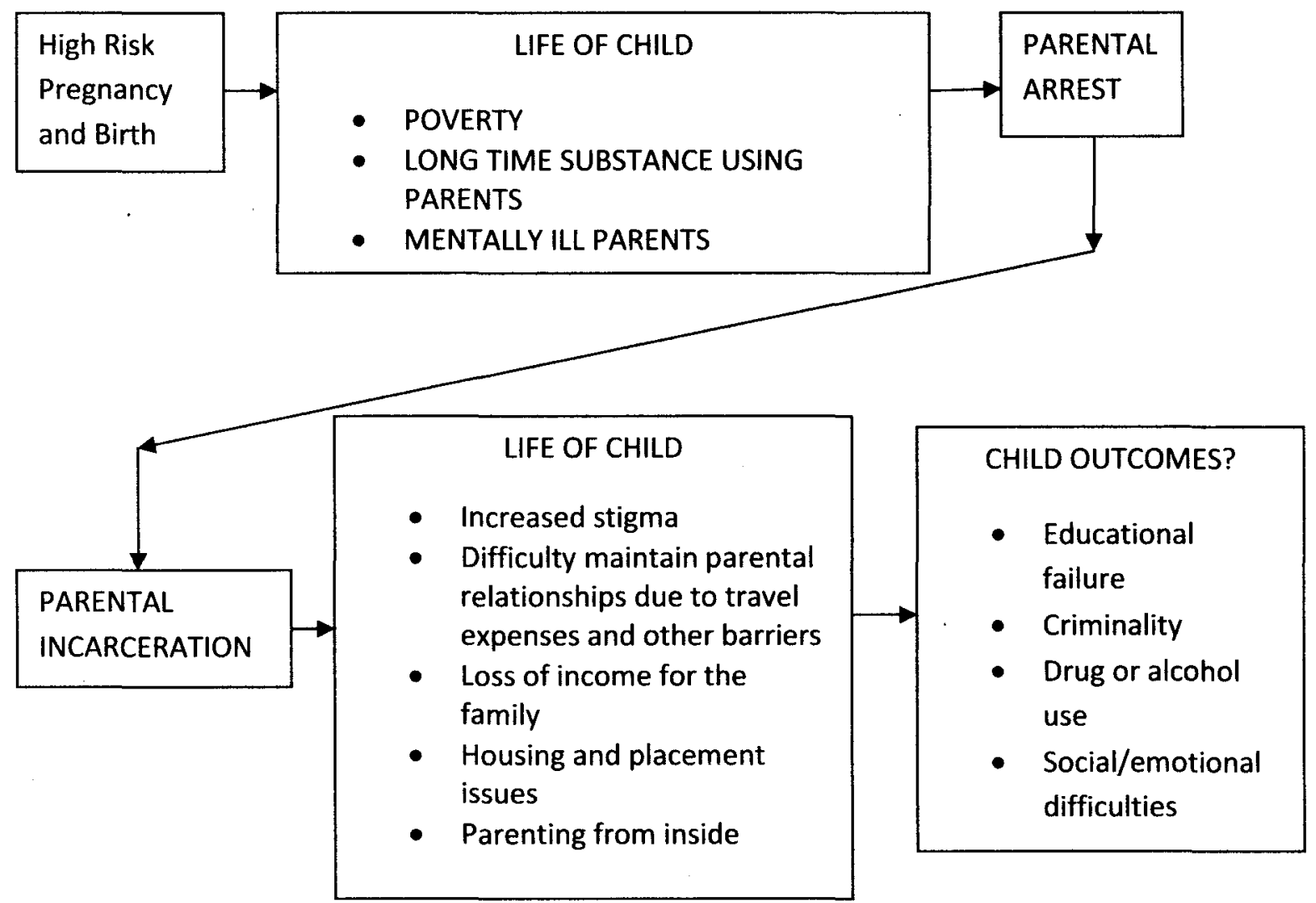

Figure 4. A Multiple Risk Model-poverty, parental substance use, parental mental illness, and parental incarceration 


\section{Parental incarceration and negative child outcomes.}

Prisoners are not only separated from society upon incarceration, but they are also separated from their children, families, and friends. The number of children impacted by parental incarceration is largely unknown due to inconsistent reporting procedures between states and many states do not capture data about prisoners' families. The rough estimate is that approximately 2 million children have a parent in prison, but some researchers consider that number to be conservative (La Vigne, et al., 2008).

As discussed, the children of incarcerated parents often face significant risks that occur before, and separate from, an experience of losing a parent to incarceration. These risks include poverty, parental mental illness, and parental substance abuse. It is also important to recognize that parental incarceration creates a unique environment for children and exerts a unique influence on child outcomes (La Vigne, et al., 2008). The removal of a parent through incarceration creates unique stressors in a child's life. Parental separation leads to difficulties in maintaining parent child relationships and placement/custody challenges (Dyer, 2005; Moses, 1995; Poehlmann, et al., 2008). There is also a significant emotional impact which often includes shame/stigma, attachment disorders, and grief and loss (Arditti, et al., 2003; Dalley, 2002; La Vigne, et al., 2008; La Vigne, et al., 2005). The economic impact of incarceration is often severe as families not only lose financial support from an incarcerated parent, but often feel obligated to support a loved one during a period of imprisonment (Hairston, 2007; Johnson, 2009; Moe \& Ferraro, 2006). Finally, there are the difficulties that occur 
when parents are released from prison and transition back into their communities and families (Hairston, Rollin, \& Jo, 2004; Moses, 2006a). Many families are irreparably damaged by a period of incarceration and never fully recover.

\section{Poverty due to incarceration.}

During a period of incarceration most families experience financial loss. The most significant loss occurs when the imprisoned family member was a contributing part of the family prior to incarceration, but many families are also burdened by the added expenses of providing money for toiletries, food, health care co-pays and collect phone calls to their family member in prison (Bloom \& Steinhart, 1993; Mackintosh, Myers, \& Kennon, 2006). If children go into the care of other family members or grandparents, oftentimes already stretched resources are further stretched to meet the costs of raising the children (La Vigne, et al., 2008; Smith, Krisman, Strozier, \& Marley, 2004).

Evidence supports the tradition that most fathers provided financial support to their children, either formal or informal, before being incarcerated. This loss of income can create a significant financial burden for those left caring for the children. The loss of a mother's income, however, can have even greater economic consequences. Most mothers who go to prison are single women who were the sole source of support for their children. Many children experience even greater levels of poverty after a parent goes to prison because they are often placed in the homes of impoverished family members. The circumstance of these family members is further burdened by the addition to their families and the difficulties created by social policies that make it hard for grandparents and other 
relative caregivers to access public assistance programs such as Temporary Assistance for Needy Families (TANF) (Miller, 2006).

The empirical gap created by the lack of data on children's economic status within the context of parental incarceration is striking. Very little attention is paid to the connection between parental incarceration and poverty, despite the likelihood that incarceration can be shown to be both the outcome of poverty and a contributor to financial strain in a family through the creation or exacerbation of financial difficulties (Arditti, et al., 2003). Mumola (2003) reports that the majority of state and federal prisoners were employed full-time in the month prior to their arrest and that their incomes were the main source of support for their families.

\section{Parental separation and maintaining parent-child relationships.}

In addition to financial burdens, there is often a high emotional toll taken on the children of prisoners. They often experience a tremendous sense of loss as relationships are disrupted. Break-ups and divorce are common, leaving families broken, or if relationships between the mother and father were already negative they are further exacerbated (Hairston \& Oliver, 2006, 2007; Nurse, 2002). Incarcerated mothers report that separation from their children is one of the most difficult, if not the most difficult, aspects of incarceration. Guilt and shame take a heavy toll as mothers and fathers struggle with the knowledge that their children's lives have been severely disrupted due to their choices and behaviors (Golden, 2005; Moe \& Ferraro, 2006). The ways in which parents and caregivers cope with this stress can greatly impact the children. Parents, both at home and in prison, may be unable to provide the nurturing and guidance that 
children need as they struggle to cope with financial and social stressors (Hairston, 1995).

The majority of incarcerated parents reside over 100 miles away from the communities of their arrests and in which their children live. Travel is often expensive and many families, struggling with financial limitations, cannot make the trip that would allow children and parents to maintain good contact and strong relationships during a period of imprisonment (Tuerk \& Loper, 2006). Phone calls may also be prohibitively expensive as collect calls from prisons often cost as much as three times more than collect calls placed from standard pay phones. Prison visiting policies and the sterile, unwelcoming environment of the prison make it additionally burdensome for families to maintain contact with incarcerated parents and family members (La Vigne, et al., 2008; La Vigne, et al., 2005).

Many children have limited contact with their parents during their imprisonments. Hairston, et al. (2004) reported that $42 \%$ of incarcerated fathers had very limited visits with their children due to having no one to bring them to prison. Another $22 \%$ reported that their child's mother would not allow them to visit. This is not surprising as $76 \%$ of children lived with their mothers prior to their fathers' incarceration and most of those women were not in committed relationships or marriages and had little motivation to bring their children to the prison on visiting day (Braman, 2004; Hairston \& Oliver, 2006).

There are multiple risk factors that contribute to negative child outcomes (as discussed: parental mental illness, parental substance abuse, and poverty), but parental incarceration does present some unique risk factors including a lack 
of control over how and when children and parents can communicate, conditions under which contact occurs, and social stigmas related to incarceration (Hairston, 2007). Children of incarcerated parents often exhibit aggression, defiance, depression, anxiety, and withdrawal. Additionally, they struggle with difficulties in school, loneliness, fear, and guilt.

\section{Emotional impact (stigma, grief, and attachment).}

Separation from a parent will always result in stress, sadness, and other negative emotions. Research shows that it matters little whether that separation is caused by death, divorce, or incarceration (La Vigne, et al., 2008). When a parent dies however, it is final and a child can cope with the loss and move on. When a parent is separated due to incarceration it is ambiguous and often difficult for children to understand. Their parents are alive, yet absent from their lives. Kampfner (1995) reported that the trauma of parental incarceration can lead to sleeplessness, depression, behavioral problems, and poor academic performance. These initial trauma responses can often develop into long term behavioral problems and difficulty coping (La Vigne, et al., 2008).

As with other risk factors, it is difficult to distinguish the effects of the separation from other risk factors already in a child's life such as parental mental illness, poverty and substance use. A recent study has been able to get closer to identifying a causal link between parental incarceration and its impact on the emotional and behavioral outcomes of children (Murray \& Farrington, 2007; Murray, Janson, \& Farrington, 2007). Negative outcomes might be caused by factors that are specific to parental incarceration including parent-child 
separation, awareness of parental criminal behaviors, poverty caused by incarceration, stigma, stress, and inferior parenting provided by those left behind (Murray \& Farrington, 2007).

It is not uncommon for families to deceive their children about their parents' incarceration either because the family is embarrassed or because they believe they are protecting the children from the knowledge of their parents' behaviors. For very young children this is not overly problematic, but as children get older the deception has been shown to have damaging consequences. The deception, though often well meaning, leads to confusion and distrust. Without the real information about where their parents are children often create scenarios that place their parents in danger or afraid which leads to chronic worrying or other emotional troubles. If the deception told to the child involves the parent being away at school or in the military, children will often developed idealized images of their parents which lead to disappointment when the truth is finally revealed (Miller, 2006).

Children of incarcerated parents are likely to feel ashamed and fear rejection from others in their environment if it is discovered. Additionally troublesome is when family members reject the children because of anger and resentment that they harbor toward the children's parents (Arditti, et al., 2003). In an attempt to avoid rejection children will often withdraw from meaningful relationships. Their egocentric viewpoints can further complicate the problem when they blame themselves for their parents' criminal behaviors and begin to 
display symptoms of depression or other emotional/behavioral disorders (Hairston, 2007; Miller, 2006).

Childcare and placement during imprisonment.

Nearly $90 \%$ of children remain in the care of their mothers when their fathers go to prison. When mothers are incarcerated, however, the majority end up in the care of grandparents or other family members. Little is known about the risks in individual care giving situations and how they impact child outcomes. The same risk factors that are detrimental when children are in the care of their parents are often also present in the homes of family caregivers (Poehlmann, 2005). Placement during periods of parental incarceration, especially maternal incarceration, can be unstable for several reasons. First, most children experience a change in their caregiver during their mother's incarceration that make it difficult for the children to develop trust and, to feel stable in their environments, and is very disrupting to developing positive relationships with their caregiver(s). Second, some children are separated from their siblings making it difficult to maintain family relationship. Third, less than half of incarcerated mothers are able to receive visits from their children due to the cost of the visits or the attitudes of the mothers or other family members about taking the children to the prison. This lack of contact makes it very difficult for mothers to sustain their relationships with their children (Poehlmann, et al., 2008).

\section{Parent-child reunification.}

Difficulties associated with enforced separation are brought into sharp focus upon reunification. The reunion is even more difficult when the children are 
young, the separation is long, and visits were infrequent (Dalley, 2002). The average incarcerated mother serves 6 years in prison. Mothers face a variety of problems when reuniting with their children, including financial difficulties, adjusting to living together again, and child behavioral problems related to transition such as bed wetting, clinging, and being distracted at school (Dalley, 2002).

In conclusion, parental incarceration may be only the most recent stressor in a child's life. Most children of incarcerated parents were already facing the risks of growing up in poverty, or with parents who use drugs or suffer from mental illnesses. Additionally, parental incarceration creates a unique set of risk factors including parental separation, the shame of incarceration, and poverty created by the loss of income when a parent is removed from the family (Johnson \& Waldfogel, 2004; Johnson, 2009)

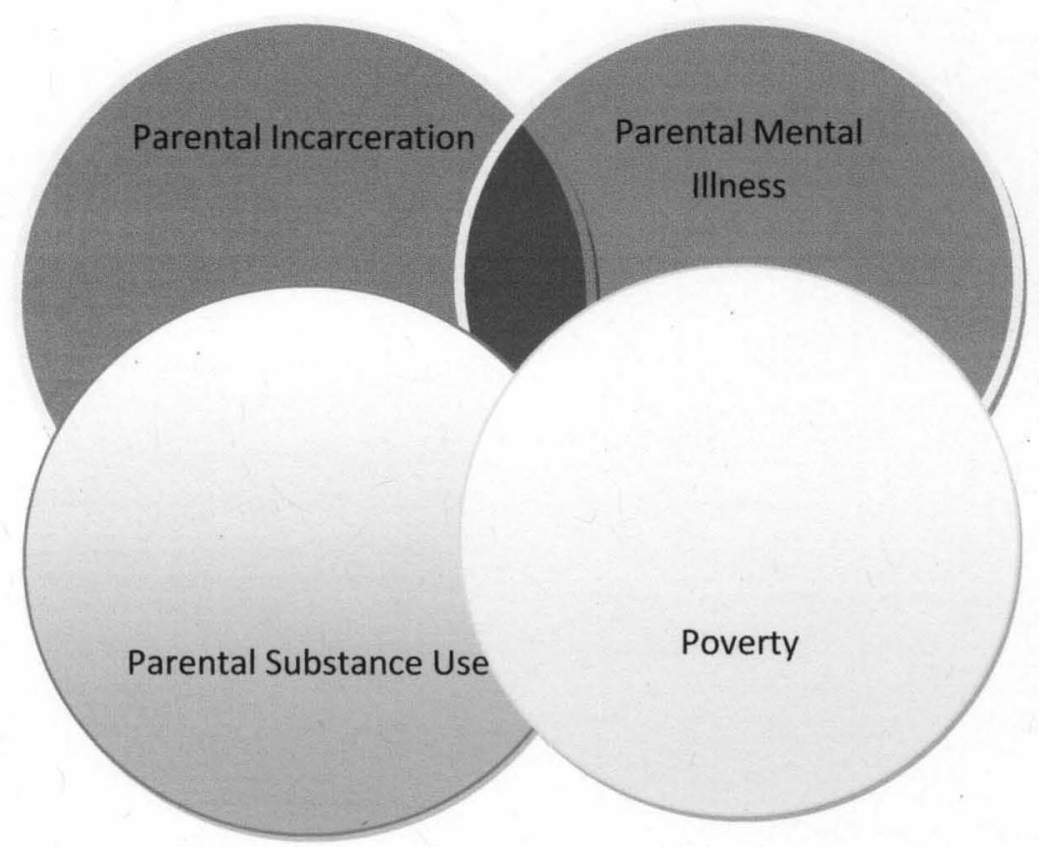

Figure 5. The Ties That Bind 
In summary, the four risk factors discussed have been shown to impact the outcomes of children in similar ways. All have been found to contribute to increased criminal behavior and substance use among adolescents, as well as poor academic performance or school failure. Additionally, the risk factors examined often lead to emotional/behavioral difficulties and other challenges related to the absence of a parent (both physically and emotionally absent) or ineffective parenting techniques. An examination of multiple risk factors and their impact on child outcomes is critical in order to fully understand the challenges faced by these children and the interventions that will most effectively improve their overall outcomes.

\section{Child Outcomes}

Examining possible child outcomes is important for a strong understanding of the impact that the risk factors already discussed often have on child behaviors, emotions, and life choices. For the purposes of this study, seven outcomes will be examined: a) school failure, b) emotional difficulties, c) behavioral difficulties, d) criminal behaviors, e) being arrested, f) alcohol use, and g) drug use.

\section{School failure.}

Educational success has been linked to positive outcomes throughout life and yet children face multiple risks that put their educational attainment in jeopardy. Parental involvement has been identified as an essential ingredient to improved student behavior and academic achievement (Cooper \& Jordan, 2003; Hill \& Taylor, 2004; Lareau, 1996). Having a parent closely involved with school 
activities allows for consistent set of rules to be communicated to a child across both home and school settings (Hill \& Taylor, 2004) and allows parents to be more involved and able to provided academic assistance to their children (Lareau, 1996). Having a parent that is abusing substances, suffering from severe mental illness, or absent due to incarceration would severely limit the capacity for and scope of parental involvement.

Poverty and social class have also been found to have significant impacts on the level of parental involvement at school. The classic case study examining this issue compared two groups of students, one with working class parents at Colton and one with professional middle-class parents at Prescott (Lareau, 1987, 2000). Colton parents viewed school as a job and something that should be left behind once the school day was done. Evenings and weekends were meant for relaxation and leisure activities. Education is something that takes place at school and should be under the direction of a teacher (Lareau, 1987).

Conversely, Prescott parents held the view that school is life. They were more likely not only to be more involved in school activities during the day, but were also more likely to be monitoring and reinforcing school work in the evening.

Additionally, those who have low educational attainment are more likely to join those living in poverty in adulthood. Those with low levels of schooling have difficulty obtaining jobs that pay enough to keep their families out of poverty. African-American and Latino men are more likely to earn below the poverty line and among those who dropped out of high school, $60 \%$ of African American, $51 \%$ of Latinos, and $38 \%$ of whites were earnings poor (Corcoran \& Chaudry, 
1997). This point also reinforces the role that race plays in poverty level and therefore educational attainment for children.

\section{Emotional/behavioral difficulties.}

Many risk factors have been shown to contribute to negative health and psychological outcomes in childhood, adolescence and into adulthood. Parental depressive disorder and other forms of psychopathology have been established as factors that raise the risk of mental disorders in children (Davenport, et al., 1984; Downey \& Coyne, 1990; Gutjahr, 2007). Other risk factors identified as contributors to childhood mental health disorders include substance abuse and chaotic family environments (Pirkola, et al., 2005).

Costello, Gordon, Keeler, and Angold (2001) examined the impact of poverty and race on the mental health of children. Black families were found to carry a heavier burden of poverty than white families. Differences in mental . health outcomes were found to be different between the races, but only among poor children. Those children who did not live in poverty had no differences in their mental health outcomes. Among those who did show a difference the most common diagnoses were depressive disorders, which were slightly more evident among Black children (Costello, Keeler, \& Angold, 2001).

In a 16-year longitudinal study that followed the development of 20 pairs of children in Sweden researchers found that the children's development and adjustment were negatively correlated with maternal alcohol/drug abuse. Additionally, the more risk factors that a child faced the greater the risk of developing psychiatric disorders later in life (Sydsjo, Wadsby, \& Svedin, 2007). 
Williams, et al. (1990) related behavioral problems in 11-year-olds to cumulative risk including numerous changes in residence and therefore schools, poverty, and low maternal cognitive ability and mental health (Williams, et al., 1990).

Poor children have been found to suffer from behavioral and emotional problems at a higher rate than their non-poor counterparts. Externalizing behaviors such as fighting and aggression and internalizing behaviors such as depression and anxiety have both been identified at a higher level in poor children (Brooks-Gunn \& Duncan, 1997). Children from persistently poor families have higher percentages of internalizing and externalizing behaviors, when maternal education and family structure were controlled (Duncan, et al., 1994). Two studies using data from the National Longitudinal survey of Youth found that children living in persistent poverty were more likely to display internalizing behaviors while those living in current poverty, but not persistent poverty, were more likely to have externalizing behaviors (Korenman, et al., 1995; McLeod \& Shanahan, 1993). Additionally, parents who are poor are more likely to be less healthy, emotionally and physically, than those who are not poor. This can lead to increased chaos and conflict in the home, decreased parental involvement, and poor parent-child interactions (Brooks-Gunn \& Duncan, 1997).

\section{Criminal behavior.}

Adult criminality has significant roots to childhood experiences. Criminal justice research has long asserted that problem behaviors during childhood are indicative of problem behaviors as adults. Researchers have documented that aggressive behaviors in childhood often predict aggressive behaviors in 
adolescence and consequently adulthood (Trembley, Vitaro, Nagin, Pagani, \& Seguin, 2003). Robins (1978) found that "adult antisocial behavior virtually requires childhood antisocial behavior" (p.611). Similarly, criminal behavior in adolescence has been linked to other negative risk factors in children's lives such as poverty, parental substance use, and parental mental illness.

\section{Substance Use.}

Deficits in parental support and poor parental control have been identified as risks for adolescent substance use (Chassin, et al., 1996). Parent drug use, parental mental illness, and parental incarceration can be significant barriers to a parent offering sufficient support to their children or being able to place appropriate controls on them. Children of alcoholics have been found to be at an elevated risk for problem alcohol use in adolescence and alcohol dependence in adulthood (Colder, et al., 1997). 


\section{CHAPTER III}

\section{METHODOLOGY}

The purpose of this study is to determine the impact of multiple risk factors on the outcomes of children. Recall the following research questions:

1. To what degree do parental risk factors influence child outcomes?

2. Are child outcomes more significantly linked to any one parental risk factor over another?

Data selected for examination come from the Children at Risk data set, publically available through the Interuniversity Consortium for Political and Social Research (ICPSR), maintained by the University of Michigan. Data were selected due to the presence of key variables within the data set, including parental characteristics and child behaviors and outcomes.

\section{Sample: The Children at Risk Program (CAR)}

The Children at Risk Program was a program designed to prevent druguse, delinquency, and other problem behaviors among children living within specific neighborhoods that were identified as severely distressed. The research project was funded by The Office of Juvenile Justice and Delinquency Prevention, other Federal agencies, and private foundations (Harrell et al., 1998). The neighborhoods were located in five US cities: Austin, TX; Bridgeport, CT; 
Memphis, TN; Seattle, WA; and Savannah, GA. For the purposes of the original program evaluation three groups were created-experimental, control, and quasi-experimental. Children in the experimental and control groups all lived in the target neighborhoods and met the other admission criteria set forth in the study. In the original study, children were randomly selected into each group and random assignment occurred at the family level so that sibling groups would be in the same study group. The quasi-experimental group was made up of a matched sample of children who met the CAR eligibility requirements, but who lived in separate neighborhoods that were determined to be equally distressed as the study neighborhoods. These children were not eligible to receive the intervention. The researchers created this group in order to control for other variables in the environment (e.g. court and school programs) that may also influence child outcomes (Harrell et al., 1998).

The original researchers examined three primary research questions:

1. Did CAR youths and families participate in more services and prosocial activities during the program than youths and families in the control and comparison groups?

2. Did CAR youths and caregivers have fewer risk factors and/or more protective factors than youths and caregivers in the control and comparison group 1 year after the program ended? 
3. Were CAR youths less likely to exhibit problem behaviors in the year following the end of the program than high-risk youths in the control group who did not receive CAR services? (Harrell, et al., 1998, p.1-2)

Harrell, et al. (1998) found that the participants of the CAR program, when compared to the control and comparison groups, were more likely to participate in positive activities, attend drug and alcohol abuse programming, utilize more services, and were less likely to report using gateway or serious drugs, selling drugs, or committing violent crimes.

Data collection occurred at three points-baseline, end of program, and follow-up. Caregiver data were collected at baseline and end of program only, while youth data were collected at all three points. Baseline data were collected during the month following recruitment. End of program data were collected approximately two years after baseline and the follow up data (youth only) were collected approximately one year after the end of program data.

The following are the eligibility criteria that each child had to meet before being eligible to participate in the original study (Harrell, et al., 1998).

Eligibility criteria for CAR

1. Youth had to be between 11 and 13 years of age.

2. Attend $6^{\text {th }}$ or $7^{\text {th }}$ grade.

3. Live in a target neighborhood.

4. Meet school, family, or personal risk factors. 
Risk requirements were any of the following:

1. At least $\underline{\mathbf{3}}$ school risk indicators (one of which has to refer to behavioral problems):
a. Special education
b. Grade retention
c. Poor academic performance
d. Truancy
e. Tardiness
f. Out of school suspension
g. Disruptive behavior in school

2. At least 1 family risk indicator
a. History of family violence or disintegration
b. Criminal conviction of a family member within the prior 5 years
c. Family involvement in gangs, drug use or drug dealing

3. At least 1 personal risk factor
a. Suspected involvement in drug use or sales
b. Under juvenile court supervision
c. Delinquency
d. Mental illness
e. Member of a gang or delinquent peer group
f. Victim of abuse or neglect 


\section{g. Pregnancy or parenthood}

The total sample was comprised of 865 children when the control, experimental, and quasi groups were combined. For the purposes of this analysis, only the baseline data will be examined as the impact of the intervention is not important to the current research questions. Power analysis for multivariate probit regression is not well developed or talked about in the literature. In linear regression models, a model more frequently applied to social science questions, the rule of thumb is ten subjects per independent variable (Tabachnick \& Fidell, 2000) If applying that rule to the current study, the sample is of adequate size to answer the research questions.

\section{Method of Analysis}

All statistical analyses were performed using STATA 11. Descriptive statistics for the study will first be presented. Given the focus on multiple risk factors and their cumulative impact, a regression would allow for the examination of how much of the variance in each of the dependent variables (outcomes) is accounted for by each independent variable (risks). The risk factors (IVs) selected include: (a) parental mental illness, (b) parental substance use, (c) parental incarceration, and (d) poverty. Child outcomes (DVs) selected include: (a) school performance, (b) criminal behavior, (c) getting arrested, (d) alcohol use, (e) drug use, (f) emotional difficulties, and ( $g$ ) behavioral difficulties. How these variables were coded is more fully discussed later in this chapter.

Risk factors and child outcomes are dichotomous, categorical variables and no ratio level variables were available for analysis. Due to the nature of the 
data available either a logitistic (logit) or probit regression is the most appropriate. A multivariate probit regression model was chosen.

\section{Probit regression model.}

In the case of univariate analysis, the probit and logit models are very similar to one another and yield very similar results (Hahn \& Soyer, 2005). Neither the logit model nor the probit models are linear and in order to make the model linear, the dependent variable is transformed. In probit models, the function used is the inverse of the standard normal cumulative distribution (zscore), but logit models are transformed using the logit function or the natural log of the odds. In reality, this difference isn't very important because both methods are equally good at linearizing the model; which one is used is a matter of personal preference (UCLA, 2009).

In situations where the dependent variables are not believed to be related it would be appropriate to use separate univariate probit models. However, in the current study, the impact of multiple risk factors on child outcomes, which are likely to be correlated, are being examined. Due to that correlation, a multivariate test would be more appropriate (Long, 1997). As a review of the literature suggests, negative child outcomes often manifest in the form of behavioral problems at home, at school, or in the community. It is likely that difficulties at home will lead to difficulties at school and children's decisions to use drugs or engage in criminal behavior that will impact their interactions with their families and their school performance. Multivariate probit models allow for the simultaneous examination of multiple dependent variables when the variables 
are believed to be related to one another. Table 6 illustrates that many of the dependent variables are highly correlated.

\section{Table 6}

\section{Correlations among Dependent Variables (Outcomes)}

\begin{tabular}{|c|c|c|c|c|c|c|c|}
\hline \multicolumn{7}{|c|}{ Correlation Table-Dependent Variables } \\
\hline & $\begin{array}{c}\text { School } \\
\text { Failure }\end{array}$ & $\begin{array}{c}\text { Criminal } \\
\text { Behavior }\end{array}$ & Arrested & $\begin{array}{c}\text { Behavioral } \\
\text { Difficulty }\end{array}$ & $\begin{array}{c}\text { Emotional } \\
\text { Difficulty }\end{array}$ & Alcohol Use & Drug Use \\
\hline School Failure & $1.0000^{\star \star \star}$ & & & & & & \\
\hline $\begin{array}{c}\text { Criminal } \\
\text { Behavior }\end{array}$ & $0.1052^{\star \star \star}$ & 1.0000 & & & & & \\
\hline Arrested & $0.1046+$ & $0.2203^{\star \star \star}$ & 1.0000 & & & & \\
\hline $\begin{array}{c}\text { Behavior } \\
\text { Difficulty }\end{array}$ & $0.0496^{\star \star \star}$ & $0.2895^{\star \star \star}$ & $0.1485^{\star \star \star}$ & 1.0000 & & & \\
\hline $\begin{array}{c}\text { Emotional } \\
\text { Difficulty }\end{array}$ & $0.1276^{\star \star \star}$ & $0.0801^{\star \star \star}$ & 0.0069 & $0.1119^{\star \star \star}$ & 1.0000 & & \\
\hline Alcohol Use & $0.0718^{\star \star}$ & $0.3520^{\star \star \star}$ & $0.1877^{\star \star \star}$ & $0.2307^{\star \star \star}$ & $0.0674^{\star \star}$ & 1.0000 & \\
\hline Drug Use & $0.0653^{*}$ & $0.3246^{\star \star \star}$ & $0.1438^{\star \star \star}$ & $0.1988^{\star \star \star}$ & $0.0812^{\star \star \star}$ & $0.7213^{\star \star \star}$ & 1.0000 \\
\hline
\end{tabular}

${ }^{* * *} p<0.01,{ }^{* *} p<0.05,{ }^{*} p<0.10,+p<0.20$

Additionally, multivariate probit models are more flexible than logit models and impose fewer restrictions on the analysis. The normal correlation distribution can be assumed and this allows for flexible modeling of the correlation structure and a straightforward interpretation of the parameters (Chib \& Greenberg, 1998). The analysis has never become popular due to the intensive nature of the calculations involved in estimating the model. Several statistical packages however, including STATA 11, now allow for these types of analyses making the test more accessible to researchers.

Muthen (1989), a well know statistician within psychometrics, uses the probit model to address multiple research questions including an analysis of symptom data for anxiety and depression. Downey, et al (2009) used the probit model to examine the end-of-life priorities of terminally ill patients and their 
intimate associates. Health service utilization and insurance coverage were also analyzed, by another set of researchers, and the probit analysis provided a way for assessing the relationship between insurance coverage and service utilization simultaneously for all five heath care services being examined (Gibbons \& Wilcox-Gok, 1998).

The following sections offer more detailed information about how each variable was defined from the existing data set. Both independent and dependent variables were transformed and recoded from original variables in the data set. This transformation was necessary to ensure that all variables were being measured the same way and a few variables were dichotomized.

\section{Variables}

\section{Independent variables (risks).}

Independent variables in this study can be examined in multiple ways. In this section, each method is briefly explored and the rationale for accepting or rejecting each method is offered. Independent variables capture the presence of possible risk factors in the children's lives. All independent variables rely on caregiver report.

There are three ways to compare statistical risk models: (1) examine each risk separately, (2) group the risks together into larger risk factors, and (3) create a risk index score (Burchinal, Roberts, Hooper, \& Zeisel, 2000). In the current study, examining each risk separately would mean that 47 individual risks variables would have to be entered into the regression equation. There are two reasons why this is problematic. First, a high number of variables require a large 
sample size to make the results valid. Second, a high degree of overlap among the variables is anticipated, as well as strong correlations among the variables that make the results invalid (Long, 1997).

The second method, grouping risks together in larger risk factors, allows the researcher to determine overall risk within several risk groups (factors) and the resulting score can then be used in the regression equation, thereby eliminating the issue of having multiple variables in one equation (Burchinal, et al., 2000). Principal component analysis is a method for reducing data that allows a coefficient to be assigned to each risk factor and a new score is generated based on a statistical determination of which components are more important, or principal. Unfortunately, the use of principal component analysis is not possible with the current data set due to missing values. In the principal component analysis any variable that has even one missing value will be given an overall score of missing. Therefore, the variables that make up the risk factors discussed below were qualitatively chosen based on my understanding of the literature and my determination of which variables were most critical to be included in the risk factor. The following variable descriptions and Tables 7-10 explain and illustrate how the variables were grouped into risk factors.

Risk factor 1: Parental mental illness.

Conceptual definition.

Parental mental illness is seen as the caregivers' reports that they are suffering from mental illnesses.

Operational definition. 
Parental mental illness was measured by caregiver question C42G (received counseling or therapy?). It was dichotomous (yes/no) and was not transformed for the purposes of analysis. It was recoded (yes=1; no=0) simply to ensure that all of the variables were measured in the same way.

\section{Table 7}

Variable Measuring Parental Mental Illness

\begin{tabular}{|c|c|c|c|c|c|}
\hline \multicolumn{2}{|c|}{ Variable } & 1 & 2 & 7 & 9 \\
\hline & & Yes & No & Refused & Missing \\
\hline $\begin{array}{c}\text { C42G } \\
\text { Received } \\
\text { counseling } \\
\text { or } \\
\text { therapy? }\end{array}$ & Original & 119 & 730 & 0 & 16 \\
\cline { 2 - 6 } & Transformed & Yes (1) & No (0) & \multicolumn{2}{|c|}{$\begin{array}{c}\text { Refused/Missing } \\
\text { (deleted) }\end{array}$} \\
\cline { 2 - 6 } & 119 & 730 & \multicolumn{2}{c|}{16} \\
\hline
\end{tabular}

Risk factor 2: Parental substance use.

Conceptual definition.

Parental substance use is seen as the caregivers' report that they are engaging in alcohol use or illicit drug use.

Operational definition.

Parental substance use is measured using caregiver question $\mathrm{C} 42 \mathrm{C}$ (drug or alcohol counseling or treatment?), CB7 (used drugs to get high?), and CB15 (other members of the household used drug?). Variables were dichotomous (yes/no) and were not transformed for purposes of analysis. They were recoded as 0 or 1 simply to ensure that all of the variables were measured in the same way. A new variable (cdrug) was generated by coding each caregiver as engaging in alcohol/substance use if they answered yes to any of the above 
questions. Therefore, one dichotomous variable for parental substance use was available for analysis: alcohol/drug use? (yes/no).

\section{Table 8}

Variables Measuring Parental Substance Use

\begin{tabular}{|c|c|c|c|c|c|}
\hline \multicolumn{2}{|c|}{ Variable } & 1 & 2 & 7 & 9 \\
\hline & & Yes & No & Refused & Missing \\
\hline \multirow{3}{*}{$\begin{array}{c}\text { C42C } \\
\text { Drug or } \\
\text { alcohol } \\
\text { counseling or } \\
\text { treatment? }\end{array}$} & Original & 30 & 819 & 0 & 0 \\
\hline & Transformed & Yes (1) & No (0) & \multicolumn{2}{|c|}{$\begin{array}{l}\text { Refused/Missing } \\
\text { (deleted) }\end{array}$} \\
\hline & & 30 & 819 & \multicolumn{2}{|c|}{0} \\
\hline \multirow{3}{*}{$\begin{array}{c}\text { CB7 } \\
\text { Used drugs to } \\
\text { get high? }\end{array}$} & Original & 33 & 813 & 0 & 18 \\
\hline & Transformed & Yes (1) & No (0) & \multicolumn{2}{|c|}{$\begin{array}{l}\text { Refused/Missing } \\
\text { (deleted) }\end{array}$} \\
\hline & & 33 & 813 & \multicolumn{2}{|c|}{18} \\
\hline \multirow{3}{*}{$\begin{array}{c}\text { CB15 } \\
\text { Other } \\
\text { members of } \\
\text { the household } \\
\text { used drugs? }\end{array}$} & Original & 54 & 583 & 0 & 228 \\
\hline & Transformed & Yes (1) & No (0) & \multicolumn{2}{|c|}{$\begin{array}{l}\text { Refused/Missing } \\
\text { (deleted) }\end{array}$} \\
\hline & & 54 & 583 & \multicolumn{2}{|c|}{228} \\
\hline \multirow[t]{2}{*}{ parentsubuse } & Created & Yes (1) & No (0) & \multicolumn{2}{|c|}{$\begin{array}{l}\text { Refused/Missing } \\
\text { (deleted) }\end{array}$} \\
\hline & & 767 & 98 & \multicolumn{2}{|c|}{$N / A$} \\
\hline
\end{tabular}

\section{Risk factor 3: Parental incarceration.}

Conceptual definition.

Parental incarceration is seen as the caregivers' reports that they had been incarcerated in the past.

Operational definition.

Parental incarceration is measured using caregiver question C19 (have you ever been to jail?). It was dichotomous (yes/no) and was not transformed for the purposes of analysis. Again, it was recoded as 0 or 1 to ensure that all of the variables were coded the same way. 


\section{Table 9}

Variable Measuring Parental Incarceration

\begin{tabular}{|c|c|c|c|c|c|}
\hline \multicolumn{2}{|c|}{ Variable } & 1 & 2 & 7 & 9 \\
\hline & & Yes & No & Refused & Missing \\
\hline $\begin{array}{c}\text { C19 } \\
\begin{array}{c}\text { Have you } \\
\text { ever been } \\
\text { to jail? }\end{array}\end{array}$ & Original & 150 & 698 & 0 & 17 \\
\cline { 2 - 6 } & Transformed & Yes (1) & No (0) & $\begin{array}{c}\text { Refused/Missing } \\
\text { (deleted) }\end{array}$ \\
\cline { 2 - 6 } & 150 & 698 & 17 \\
\hline
\end{tabular}

\section{Risk factor 4: Poverty.}

Conceptual definition.

Poverty is seen as the caregivers' reports that they receive one of several public benefits for which income eligibility requirements exist.

\section{Operational definition.}

Poverty is measured using caregiver question C48A (currently receive food stamps?), C48B (currently receive AFDC?), and C48C (currently receive social security?). Variables were dichotomous (yes/no) and were not transformed for purposes of analysis, but they were recoded as 0 or 1 to ensure that all variables were measured the same. A new variable (cpoverty) was generated by coding each caregiver as living in poverty if they answered yes to any of the above questions. Therefore, one dichotomous variable for poverty (cpoverty) was available for analysis: Do you receive public assistance? (yes/no). 
Table 10

Variables Measuring Poverty

\begin{tabular}{|c|c|c|c|c|c|}
\hline \multicolumn{2}{|c|}{ Variable } & 1 & 2 & 7 & 9 \\
\hline & & Yes & No & Refused & Missing \\
\hline \multirow{3}{*}{$\begin{array}{l}\text { C48A } \\
\text { Currently } \\
\text { receive } \\
\text { food } \\
\text { stamps? }\end{array}$} & Oriqinal & 515 & 327 & 0 & 23 \\
\hline & \multirow[t]{2}{*}{ Transformed } & Yes (1) & No (0) & \multicolumn{2}{|c|}{$\begin{array}{l}\text { Refused/Missing } \\
\text { (deleted) }\end{array}$} \\
\hline & & 515 & 327 & \multicolumn{2}{|c|}{23} \\
\hline \multirow{3}{*}{$\begin{array}{l}\text { C48B } \\
\text { Currently } \\
\text { receive } \\
\text { AFDC? }\end{array}$} & Original & 402 & 440 & 0 & 23 \\
\hline & \multirow[t]{2}{*}{ Transformed } & Yes (1) & No $(0)$ & \multicolumn{2}{|c|}{$\begin{array}{l}\text { Refused/Missing } \\
\text { (deleted) }\end{array}$} \\
\hline & & 402 & 440 & \multicolumn{2}{|c|}{23} \\
\hline \multirow{3}{*}{$\begin{array}{l}\text { C48C } \\
\text { Currently } \\
\text { receive } \\
\text { social } \\
\text { security? }\end{array}$} & Original & 190 & 647 & 0 & 28 \\
\hline & Transformed & Yes (1) & No (0) & \multicolumn{2}{|c|}{$\begin{array}{l}\text { Refused/Missing } \\
\text { (deleted) }\end{array}$} \\
\hline & & 190 & 647 & \multicolumn{2}{|c|}{28} \\
\hline \multirow[t]{2}{*}{ cpoverty } & \multirow[t]{2}{*}{ Created } & Yes (1) & No (0) & \multirow{2}{*}{\multicolumn{2}{|c|}{$\begin{array}{l}\text { Refused/Missing } \\
\text { (deleted) }\end{array}$}} \\
\hline & & 608 & 257 & & \\
\hline
\end{tabular}

The third, and final, method of dealing with the independent variables calls for the creation of a risk index which creates an overall risk score by rating children individually by the number of risks present in their lives. For example, children living in poverty with no parent in jail, with mental illness, or with a substance use issue would be scored as 1 . Children with two of the identified risk factors would receive scores of 2 , and so on. This method allows the researcher to easily evaluate the impact of the accumulation of risk and it is favorable when the independent variables are likely to be highly correlated (Burchinal, et al., 2000). Table 11 shows the number of children who fall within the different risk scores on the risk index. 


\section{Table 11}

\section{Risk Index Scores}

\begin{tabular}{|c|c|c|c|c|c|}
\hline & \multicolumn{5}{|c|}{ Number of Risks } \\
\hline & 0 & 1 & 2 & 3 & 4 \\
\hline $\begin{array}{c}\text { Number of } \\
\text { Children }\end{array}$ & 161 & 458 & 177 & 44 & 7 \\
\hline
\end{tabular}

A drawback of the both the $2^{\text {nd }}$ and $3^{\text {rd }}$ methods is that they assume that all of the risks are equal and, therefore, impact a child in a similar way. The literature, however, does not support this assumption. For example, a child who has a parent who uses substances, but the family does not live in poverty, because the parents are able to work, and the parents do not suffer from mental illness or have not spent time in jail would be scored as a 1. Other children would also receive scores of 1 if their parents were severely mentally ill with no other risk factors. It is apparent that the actual level of risk to these two children is likely to be different. Because individual children and families are complex it is problematic to assume that risk manifests itself similarly in all families. Despite that, the use of risk factors and risk index scores to evaluate risk is well documented in the literature as a way of evaluating multiple risk models (Anda, et al., 2002; Avalos-Jordan, 2008; Burchinal, et al., 2000; Chapman, et al., 2007; Johnson \& Waldfogel, 2004; Johnson, 2009; Mather \& Adams, 2006; Pirkola, et al., 2005). Both risk factor analysis and risk index analysis were examined to determine the similarities and the differences in the approaches. Additionally, a significant contribution of this study is that the use of a multivariate probit regression model will allow the effects of each risk factor to be separated out 
from other risks so that differences in outcomes in the presence of different risks can be assessed. This allows the researcher to determine if different risks impact children in different ways rather than forcing the assumption that all risks impact children in similar ways.

\section{Dependent variables (outcomes).}

All dependent variables available for analysis were categorical, with the majority of them being dichotomous. In order to utilize multivariate probit regression techniques it was necessary to transform categorical variables that were not already dichotomous into dichotomous variables so that all variables entered into the regression equation were measured in the same way. Additionally, many of the dependent variables asked separate questions to address a variety of problem behaviors and child outcomes (for example, have you used pot and have you used cocaine rather than a general question about drug use). Again, for the purposes of analysis, these variables were combined into larger categories such as drug/alcohol use and crime. Entering a large number of variables into the regression equation would make the test less robust. A detailed account of how variables were transformed and/or combined follows. The dependent variables capture aspects of children's behaviors and emotional wellbeing. Just as the independent variable data results from caregivers' self report, each of the dependent variables relied on youths' self report.

\section{Child outcome 1: School failure.}

Conceptual definition. 
School failure is seen as the extent to which children are performing well enough that they are moving toward promotion to the next grade level.

\section{Operational definition.}

School failure was measured by youth question Q41. Youth indicated whether they expected to be promoted to the next grade. The original response was coded as probably would, maybe would, probably would not, and definitely would not. The variable was dichotomized for the purpose of analysis by coding probably would and maybe would as yes and probably would not and definitely would not as no.

Table 12

Variables Measuring School Failure

\begin{tabular}{|c|c|c|c|c|c|c|c|c|}
\hline Variable & & 1 & 2 & 3 & 4 & 7 & 8 & 9 \\
\hline & & $\begin{array}{l}\text { Probably } \\
\text { would }\end{array}$ & $\begin{array}{l}\text { Maybe } \\
\text { would }\end{array}$ & $\begin{array}{l}\text { Probably } \\
\text { wouldn't }\end{array}$ & $\begin{array}{l}\text { Definitely } \\
\text { wouldn't }\end{array}$ & Refused & $\begin{array}{l}\text { Don't } \\
\text { know }\end{array}$ & Missing \\
\hline \multirow{3}{*}{$\begin{array}{l}\text { Q41 } \\
\text { Will you } \\
\text { be } \\
\text { promoted } \\
\text { to the } \\
\text { next } \\
\text { grade? }\end{array}$} & Original & 437 & 353 & 45 & 15 & 0 & 0 & 15 \\
\hline & \multirow[t]{2}{*}{ Transform } & \multicolumn{2}{|c|}{ Yes (1) } & \multicolumn{2}{|c|}{$\mathrm{No}(0)$} & \multicolumn{3}{|c|}{ Missing (deleted) } \\
\hline & & \multicolumn{2}{|c|}{790} & \multicolumn{2}{|c|}{60} & \multicolumn{3}{|c|}{15} \\
\hline
\end{tabular}

Child outcome 2 and 3: Criminal behavior and being arrested.

Conceptual definition.

Criminal behavior is seen as the children's reports that they had ever engaged in one of several criminal activities. Being arrested was assessed by the children's reports that they had ever been arrested.

Operational definition. 
Being arrested was measured by youth question Q35E (have you ever been arrested?) and criminal behaviors were measured using a combination of variables including: Q31B (are you a member of gangs?), QB10 (have you taken something worth over $\$ 50$ ?), QB12 (taken a car?), QB14 (set fire to someone else's property?), QB15 (damaged someone else's property?), QB18 (made someone give you money?), QB19 (attacked someone?), QB20 (forced someone to do sexual acts?), QB21 (carried a weapon?), QC10 (ever helped with drug sales?), QC11 (ever sold drugs directly?). Q35E (have you ever been arrested?) is a dichotomous variable (yes/no) and was not transformed for purposes of the analysis. It was recoded to ensure that all the variables were measured in the same way. A new variable (ycrime) was generated by uniformly coding the already dichotomized variables (yes/no), and then coding each child as engaging in criminal behavior if they answered yes to any of the above questions. Therefore, two dichotomous variables for criminal behavior were available for analysis: Have you ever been arrested? (yes/no) and Have you engaged in criminal behaviors? (yes/no). 


\section{Table 13}

\section{Variables Measuring Criminal Behaviors}

\begin{tabular}{|c|c|c|c|c|c|c|c|}
\hline \multicolumn{2}{|c|}{$\begin{array}{c}\text { Dichotomized } \\
\text { Variables }\end{array}$} & \multirow{2}{*}{$\begin{array}{c}1 \\
\text { Never }\end{array}$} & \multirow{2}{*}{$\begin{array}{c}2 \\
1-2 \\
\text { times }\end{array}$} & \multirow{2}{*}{$\begin{array}{c}3 \\
3-4 \\
\text { times }\end{array}$} & \multirow{2}{*}{$\begin{array}{c}4 \\
5 \text { times } \\
\text { or more }\end{array}$} & \multirow{2}{*}{$\begin{array}{c}7 \\
\text { Refused }\end{array}$} & \multirow{2}{*}{$\begin{array}{c}9 \\
\text { Missing }\end{array}$} \\
\hline & & & & & & & \\
\hline \multirow{3}{*}{$\begin{array}{c}\text { QB10 } \\
\text { Have you } \\
\text { taken } \\
\text { something } \\
\text { work over } \\
\$ 50 ?\end{array}$} & original & 760 & 75 & 5 & 12 & 0 & 13 \\
\hline & \multirow[t]{2}{*}{ Transform } & No $(0)$ & \multicolumn{3}{|c|}{ Yes (1) } & \multicolumn{2}{|c|}{$\begin{array}{c}\text { Missing/refused } \\
\text { (deleted) }\end{array}$} \\
\hline & & 760 & & 92 & & & \\
\hline \multirow{3}{*}{$\begin{array}{c}\text { QB12 } \\
\text { Taken a } \\
\text { car? }\end{array}$} & Original & 815 & 29 & 5 & 1 & 0 & 15 \\
\hline & \multirow[t]{2}{*}{ Transform } & No (0) & \multicolumn{3}{|c|}{ Yes (1) } & \multicolumn{2}{|c|}{$\begin{array}{l}\text { Missing/refused } \\
\text { (deleted) }\end{array}$} \\
\hline & & 815 & \multicolumn{3}{|c|}{35} & \multicolumn{2}{|c|}{15} \\
\hline \multirow{3}{*}{$\begin{array}{c}\text { QB14 } \\
\text { Set fire to } \\
\text { someone } \\
\text { else's } \\
\text { property? }\end{array}$} & Original & 819 & 28 & 3 & 0 & & \\
\hline & Transform & No $(0)$ & \multicolumn{3}{|c|}{ Yes (1) } & \multicolumn{2}{|c|}{$\begin{array}{c}\text { Missing/refused } \\
\text { (deleted) }\end{array}$} \\
\hline & & 819 & \multicolumn{3}{|c|}{31} & \multicolumn{2}{|c|}{15} \\
\hline \multirow{3}{*}{$\begin{array}{c}\text { QB15 } \\
\text { Damaged } \\
\text { someone } \\
\text { else's } \\
\text { property? }\end{array}$} & Original & 682 & 136 & 18 & 13 & & \\
\hline & Transform & No (0) & \multicolumn{3}{|c|}{ Yes (1) } & \multicolumn{2}{|c|}{$\begin{array}{c}\text { Missing/refused } \\
\text { (deleted) }\end{array}$} \\
\hline & & 682 & \multicolumn{3}{|c|}{167} & \multicolumn{2}{|c|}{16} \\
\hline \multirow{3}{*}{$\begin{array}{l}\text { QB18 } \\
\text { Made } \\
\text { someone } \\
\text { give you } \\
\text { money? }\end{array}$} & Original & 786 & 48 & 9 & 7 & & \\
\hline & Transform & No (0) & \multicolumn{3}{|c|}{ Yes (1) } & \multicolumn{2}{|c|}{$\begin{array}{c}\text { Missing/refused } \\
\text { (deleted) }\end{array}$} \\
\hline & & 786 & \multicolumn{3}{|c|}{93} & \multicolumn{2}{|c|}{15} \\
\hline & Original & 758 & 73 & 13 & 7 & & \\
\hline $\begin{array}{l}\text { Attacked } \\
\text { someone? }\end{array}$ & Transform & No (0) & & Yes (1) & & $\begin{array}{l}\text { Missing } \\
\text { (de) }\end{array}$ & $\begin{array}{l}\text { refused } \\
\text { ted) }\end{array}$ \\
\hline & & 758 & & 129 & & & \\
\hline QB20 & Original & 837 & 10 & 1 & 3 & & \\
\hline $\begin{array}{l}\text { Forced } \\
\text { someone }\end{array}$ & Transform & No (0) & & Yes (1) & & $\begin{array}{l}\text { Missing } \\
\text { (de) }\end{array}$ & $\begin{array}{l}\text { refused } \\
\text { ted) }\end{array}$ \\
\hline $\begin{array}{l}\text { to do } \\
\text { sexual } \\
\text { acts? }\end{array}$ & & 837 & & 14 & & & \\
\hline QB21 & Original & 650 & 130 & 34 & 30 & & \\
\hline $\begin{array}{l}\text { Carried a } \\
\text { weapon? }\end{array}$ & Transform & No (0) & & Yes (1) & & $\begin{array}{c}\text { Missing } \\
\text { (de) }\end{array}$ & $\begin{array}{l}\text { refused } \\
\text { ted) }\end{array}$ \\
\hline & & 650 & & 194 & & & \\
\hline
\end{tabular}


Table 14

Variables Measuring Criminal Behavior and Being Arrested

\begin{tabular}{|c|c|c|c|c|c|}
\hline \multicolumn{2}{|c|}{ Recoded Variables } & 1 & 2 & 7 & 9 \\
\hline & & Yes & No & Refused & Missing \\
\hline \multirow{3}{*}{$\begin{array}{c}\text { Q35E } \\
\text { Have you } \\
\text { ever been } \\
\text { arrested? }\end{array}$} & Original & 68 & 784 & 1 & 12 \\
\hline & \multirow[t]{2}{*}{ Transform } & Yes (1) & No $(0)$ & \multicolumn{2}{|c|}{$\begin{array}{l}\text { Refused/Missing } \\
\text { (deleted) }\end{array}$} \\
\hline & & 68 & 784 & \multicolumn{2}{|c|}{13} \\
\hline \multirow{3}{*}{$\begin{array}{c}\text { Q31B } \\
\text { Are you a } \\
\text { member of } \\
\text { gangs? }\end{array}$} & Original & 12 & 428 & 0 & 425 \\
\hline & \multirow[t]{2}{*}{ Transform } & Yes (1) & No $(0)$ & \multicolumn{2}{|c|}{$\begin{array}{l}\text { Refused/Missing } \\
\text { (deleted) }\end{array}$} \\
\hline & & 12 & 428 & \multicolumn{2}{|c|}{425} \\
\hline \multirow{3}{*}{$\begin{array}{l}\text { QC10 } \\
\text { Ever } \\
\text { helped with } \\
\text { drug } \\
\text { sales? }\end{array}$} & Original & 55 & 793 & 0 & 17 \\
\hline & \multirow[t]{2}{*}{ Transform } & Yes (1) & No $(0)$ & \multicolumn{2}{|c|}{$\begin{array}{l}\text { Refused/Missing } \\
\text { (deleted) }\end{array}$} \\
\hline & & 55 & 793 & \multicolumn{2}{|c|}{17} \\
\hline \multirow{3}{*}{$\begin{array}{l}\text { QC11 } \\
\text { Ever sold } \\
\text { drugs } \\
\text { directly? }\end{array}$} & Original & 39 & 810 & 0 & 16 \\
\hline & Transform & Yes (1) & No $(0)$ & \multicolumn{2}{|c|}{$\begin{array}{l}\text { Refused/Missing } \\
\text { (deleted) }\end{array}$} \\
\hline & & 39 & 810 & \multicolumn{2}{|c|}{16} \\
\hline \multirow[t]{2}{*}{ ycrime } & \multirow[t]{2}{*}{ Created } & Yes (1) & No $(0)$ & \multicolumn{2}{|c|}{$\begin{array}{l}\text { Refused/Missing } \\
\text { (deleted) }\end{array}$} \\
\hline & & 852 & 13 & \multicolumn{2}{|c|}{$N / A$} \\
\hline
\end{tabular}

\section{Child outcome 4 and 5: Emotional and behavioral difficulties}

Conceptual definition.

Emotional difficulties are seen as the children's reports of struggling with emotional problems such sadness or feeling of worthlessness. Behavioral difficulties are seen as the children's reports of a common behavioral issue-fighting.

Operational definition.

Behavioral difficulties was measured by youth question (serious fight in school?) and emotional difficulties was measured using a combination of variables including: Q21F (feeling sad a problem?), QA1B (life seems meaningless), QA1D (I do not have much to be proud of), QA1E (I am a person of worth), QA1L (can't 
do anything right), and QA1M (my life is not very useful). All variables were dichotomized to create binary (yes/no) variables. A new variable (yemotion) was generated by using the newly created dichotomous variables and then coding each child as having emotional difficulties if they answered yes to any of the above questions.

\section{Table 15}

\section{Variables Measuring Emotional and Behavioral Difficulties}

\begin{tabular}{|c|c|c|c|c|c|c|c|c|}
\hline \multicolumn{2}{|c|}{ Dichotomized Variables } & 1 & 2 & 3 & 4 & 7 & 8 & 9 \\
\hline & & Agree & $\begin{array}{l}\text { Somewhat } \\
\text { Agree }\end{array}$ & $\begin{array}{l}\text { Somewhat } \\
\text { Disagree }\end{array}$ & Disagree & Refused & $\begin{array}{l}\text { Don't } \\
\text { Know }\end{array}$ & Missing \\
\hline \multirow{3}{*}{$\begin{array}{c}\text { QA1B } \\
\text { Life seems } \\
\text { meaningless }\end{array}$} & Original & 144 & 145 & 90 & 470 & 0 & 0 & 16 \\
\hline & \multirow[t]{2}{*}{ Transform } & \multicolumn{2}{|c|}{ Yes (1) } & \multicolumn{2}{|c|}{$\mathrm{No}(0)$} & \multicolumn{3}{|c|}{ Missing (deleted) } \\
\hline & & \multicolumn{2}{|r|}{289} & \multicolumn{2}{|c|}{560} & \multicolumn{3}{|c|}{16} \\
\hline \multirow{3}{*}{$\begin{array}{c}\text { QA1D } \\
\text { I do not } \\
\text { have much } \\
\text { to be proud } \\
\text { of. }\end{array}$} & Original & 124 & 78 & 71 & 579 & 0 & 0 & 13 \\
\hline & \multirow[t]{2}{*}{ Transform } & \multicolumn{2}{|c|}{ Yes (1) } & \multicolumn{2}{|c|}{$\mathrm{No}(0)$} & \multicolumn{3}{|c|}{ Missing (deleted) } \\
\hline & & \multicolumn{2}{|r|}{202} & \multicolumn{2}{|c|}{650} & \multicolumn{3}{|c|}{13} \\
\hline \multirow{3}{*}{$\begin{array}{l}\text { QA1E } \\
\text { I am a } \\
\text { person of } \\
\text { worth. }\end{array}$} & Original & 594 & 121 & 46 & 87 & 0 & 0 & 17 \\
\hline & \multirow[t]{2}{*}{ Transform } & \multicolumn{2}{|c|}{ Yes (0) } & \multicolumn{2}{|c|}{$\mathrm{No}(1)$} & \multicolumn{3}{|c|}{ Missing (deleted) } \\
\hline & & \multicolumn{2}{|r|}{715} & \multicolumn{2}{|c|}{133} & \multicolumn{3}{|c|}{17} \\
\hline \multirow{3}{*}{$\begin{array}{c}\text { QA1L } \\
\text { I can't do } \\
\text { anything } \\
\text { right. }\end{array}$} & Original & 92 & 93 & 95 & 572 & 0 & 0 & 13 \\
\hline & \multirow[t]{2}{*}{ Transform } & \multicolumn{2}{|c|}{ Yes (1) } & \multicolumn{2}{|c|}{$\mathrm{No}(\mathrm{O})$} & \multicolumn{3}{|c|}{ Missing (deleted) } \\
\hline & & \multicolumn{2}{|r|}{185} & \multicolumn{2}{|c|}{667} & \multicolumn{3}{|c|}{13} \\
\hline \multirow{3}{*}{$\begin{array}{c}\text { QA1M } \\
\text { My life is not } \\
\text { very useful. }\end{array}$} & Original & 72 & 72 & 73 & 635 & 0 & 0 & 13 \\
\hline & \multirow[t]{2}{*}{ Transform } & & es (1) & & & Mis & ing $(d e$ & ted) \\
\hline & & & 144 & & & & 13 & \\
\hline Yemotion & Created & & es (1) & & & Mis. & ing (de & ted) \\
\hline & & & 570 & & & & N/A & \\
\hline
\end{tabular}

\section{Child outcome 6 and 7: Alcohol and drug substance use.}

\section{Conceptual definition.}

Alcohol and drug use is seen as the children's reports that that they had ever engaged in the use of alcohol or any of multiple illicit or prescription drugs. 


\section{Operational definition.}

Alcohol use was measured by youth question QC1 (ever used alcohol?) and substance use was measuring using a combination of variables including: QC2 (ever sniffed glue?), QC3 (ever used marijuana?), QC4 (ever used psychedelics?), QC5 (ever used crack cocaine?), QC6 (ever used other forms of cocaine?), QC7 (ever taken a pill for a non-medical reason?), QC8 (ever used heroin?), and QC9 (ever used drugs with a needle?). Variables were dichotomous (yes/no) and were recoded only to ensure that all variables were coded in the same way. Variables for this outcome were not transformed for the purpose of analysis. A new variable (ydrug) was generated by coding each child as engaging in substance use if they answered yes to any of the above questions. Therefore, two dichotomous variables for alcohol/substance use were available for analysis: Have you ever used alcohol? (yes/no) and Have you ever used drugs? (yes/no). 
Table 16

Variables Measuring Alcohol and Drug Use

\begin{tabular}{|c|c|c|c|c|c|}
\hline \multicolumn{2}{|c|}{ Recoded Variables } & 1 & 2 & 7 & 9 \\
\hline & & Yes & No & Refused & Missing \\
\hline \multirow{3}{*}{$\begin{array}{c}\text { QC1 } \\
\text { Ever used } \\
\text { alcohol? }\end{array}$} & Original & 256 & 599 & 0 & 10 \\
\hline & \multirow[t]{2}{*}{ Transform } & Yes (1) & No $(0)$ & \multicolumn{2}{|c|}{$\begin{array}{l}\text { Refused/Missing } \\
\text { (deleted) }\end{array}$} \\
\hline & & 256 & 599 & \multicolumn{2}{|c|}{10} \\
\hline \multirow{3}{*}{$\begin{array}{c}\text { QC2 } \\
\text { Ever sniffed } \\
\text { glue? }\end{array}$} & Original & 119 & 731 & 0 & 15 \\
\hline & \multirow[t]{2}{*}{ Transform } & Yes (1) & No $(0)$ & \multicolumn{2}{|c|}{$\begin{array}{l}\text { Refused/Missing } \\
\text { (deleted) }\end{array}$} \\
\hline & & 119 & 731 & \multicolumn{2}{|c|}{15} \\
\hline \multirow{3}{*}{$\begin{array}{c}\text { QC3 } \\
\text { Ever used } \\
\text { marijuana? }\end{array}$} & Original & 93 & 760 & 0 & 12 \\
\hline & \multirow[t]{2}{*}{ Transform } & Yes (1) & No $(0)$ & \multicolumn{2}{|c|}{$\begin{array}{l}\text { Refused/Missing } \\
\text { (deleted) }\end{array}$} \\
\hline & & 93 & 760 & \multicolumn{2}{|c|}{12} \\
\hline \multirow{3}{*}{$\begin{array}{c}\text { QC4 } \\
\text { Ever used } \\
\text { psychedelics? }\end{array}$} & Original & 40 & 815 & 0 & 10 \\
\hline & \multirow[t]{2}{*}{ Transform } & Yes (1) & No $(0)$ & \multicolumn{2}{|c|}{$\begin{array}{l}\text { Refused/Missing } \\
\text { (deleted) }\end{array}$} \\
\hline & & 40 & 815 & \multicolumn{2}{|c|}{10} \\
\hline \multirow{3}{*}{$\begin{array}{c}\text { QC5 } \\
\text { Ever used } \\
\text { crack } \\
\text { cocaine? }\end{array}$} & Original & 25 & 830 & 0 & 10 \\
\hline & \multirow[t]{2}{*}{ Transform } & Yes (1) & No (0) & \multicolumn{2}{|c|}{$\begin{array}{l}\text { Refused/Missing } \\
\text { (deleted) }\end{array}$} \\
\hline & & 25 & 830 & \multicolumn{2}{|c|}{10} \\
\hline \multirow{3}{*}{$\begin{array}{c}\text { QC6 } \\
\text { Ever used } \\
\text { other forms of } \\
\text { cocaine? }\end{array}$} & Original & 32 & 822 & 0 & 11 \\
\hline & \multirow[t]{2}{*}{ Transform } & Yes (1) & No $(0)$ & \multicolumn{2}{|c|}{$\begin{array}{l}\text { Refused/Missing } \\
\text { (deleted) }\end{array}$} \\
\hline & & 31 & 822 & \multicolumn{2}{|c|}{11} \\
\hline \multirow{3}{*}{$\begin{array}{c}\text { QC7 } \\
\text { Ever taken a } \\
\text { pill for a non- } \\
\text { medical } \\
\text { reason? }\end{array}$} & Original & 55 & 800 & 0 & 10 \\
\hline & \multirow[t]{2}{*}{ Transform } & Yes (1) & No (0) & \multicolumn{2}{|c|}{$\begin{array}{l}\text { Refused/Missing } \\
\text { (deleted) }\end{array}$} \\
\hline & & 55 & 800 & \multicolumn{2}{|c|}{10} \\
\hline \multirow{3}{*}{$\begin{array}{c}\text { QC8 } \\
\text { Ever used } \\
\text { heroin? }\end{array}$} & Original & 39 & 816 & 0 & 10 \\
\hline & Transform & Yes (1) & No (0) & \multicolumn{2}{|c|}{$\begin{array}{l}\text { Refused/Missing } \\
\text { (deleted) }\end{array}$} \\
\hline & & 39 & 816 & & \\
\hline QC9 & Original & 15 & 836 & 0 & 14 \\
\hline $\begin{array}{l}\text { Ever used } \\
\text { drugs with a }\end{array}$ & Transform & Yes (1) & No (0) & $\begin{array}{r}\text { Refuse } \\
(d e\end{array}$ & $\begin{array}{l}\text { Missing } \\
\text { ted) }\end{array}$ \\
\hline needle? & & 15 & 836 & & \\
\hline Ydrug & Created & Yes (1) & No (0) & Refuse & $\begin{array}{l}\text { Missing } \\
\text { ted) }\end{array}$ \\
\hline & & 385 & 480 & & \\
\hline
\end{tabular}

In conclusion, the data were analyzed using multivariate probit regression models. This method was chosen because of the nature of the available data 
(binary independent and dependent variables) and the correlation between the dependent variables. The independent variables (risks) were used in the analysis in two ways. First, the individual risk variables were grouped together into risk factors. Second, children were assigned risk index scores based on the number of risks present in their lives. Both methods of grouping the independent variables were examined using a multivariate probit regression model. The use of a risk index helps to control for any possible correlations between the independent variables. 


\section{CHAPTER IV}

\section{RESULTS}

\section{Introduction}

The primary focus of this research study is to examine the impact of parental characteristics on child outcomes. Parental characteristics to be examined include parental mental illness, parental substance use, parental incarceration, and poverty. Previous research on these risk factors have indicated that each contribute to negative child outcomes (Colder, et al., 1997; Corcoran \& Chaudry, 1997; Downey \& Coyne, 1990; Johnson, 2009). A multiple risk model was proposed and examined to determine the impact of multiple, or accumulating, risks in a child's life and to determine if any one risk factor had a greater impact on child outcomes when other risk factors were controlled for. Multiple risk models have been examined in the social sciences to test the effect of the accumulation of risk on child outcomes and look at various risks ranging from poverty to peer influences to personal characteristics (Sameroff, et al., 1998). The important and novel contribution of this study is the addition of a critical parental risk factor that has been inadequately studied as it relates to other risks in a child's life and the subsequent child outcomes-parental incarceration. 
Parental incarceration has been shown to impact child outcomes, but intrinsically it is known that parental incarceration does not occur by itself and it is often accompanied by other significant risk factors that have also been shown to affect child outcomes. Parental incarceration, however, contributes a unique set of risk factors (parental separation, emotional stigma and attachment, etc.) that could further place a child at risk (Johnson, 2009). Previous research on parental incarceration often fails to distinguish between the effects of parental incarceration over the effects of other risk factors that exist in a child's life prior to a period of incarceration. This task is difficult due to the types of data available and the compounding nature of risk.

Are all risks created equal? Is it just a simple accumulation of risk, regardless of the nature of the risk, which leads to negative outcomes? Or, do specific risks impact children in specific ways? Can primary risk factors be identified that are more likely to negatively impact children when children often exist in complicated environments and face multiple risk factors at the same time? If so, which risk factors should be most aggressively targeted by social policies in order to improve the lives and outcomes of our children? These guiding questions led to the two primary research questions of this study.

1. To what degree do parental risk factors impact child outcomes?

2. Are child outcomes more significantly linked to any one parental risk factor over another?

All analyses were completed using STATA 11. First, demographics and other descriptive statistics are presented to allow for a broader understanding of 
the sample. Second, a multivariate probit regression model is examined to more directly address the two primary research questions. The current study examines the differences between variables to determine the impact of parental risk factors on child outcomes. Differences between groups or sub-groups within the sample were not examined as it is outside of the scope of the stated research questions. Possible person centered approaches to examine between groups differences will be discussed as an area for further research.

\section{Demographics}

The Children at Risk (CAR) program consisted of 876 youth ranging in age from 10 to 13 years old. The majority of participants were $13(44.5 \%)$ or 12 (43.7\%). African-Americans made up $57.7 \%$ of the sample. Other ethnic groups represented included Hispanic (34\%), white (5.7\%), and Asian (1.7\%). The sample was split fairly evenly on gender with $51.1 \%$ being male and $48.4 \%$ being female. Mothers represented the majority of caregivers at $79.9 \%$, while fathers (7.6\%) and grandmothers $(6.4 \%)$ represented the next largest groups.

Table 17 describes the sample in relationship to the major variables being examined in the study (risk factors include parental mental illness, parental substance use, parental incarceration, and poverty; outcomes include school failure, criminal behavior, getting arrested, behavioral difficulties, emotional difficulties, alcohol use and drug use). The most prevalent parental characteristic was poverty with over $71 \%$ reporting that they were currently experiencing poverty, as defined by their receiving public assistance. Parental incarceration was present in just over $17 \%$ of the sample and parental mental illness and 
parental substance use were similar at $13 \%$ and $11 \%$ respectively. When examining the dependent variables (school failure, criminal behavior, getting arrested, behavioral difficulties, emotional difficulties, alcohol use and drug use) the most prevalent characteristic was emotional difficulty ( $66 \%)$, following by drug use (45\%), behavioral difficulties (42\%) and criminal behaviors $(41 \%)$.

\section{Table 17}

\section{Descriptive Statistics}

\begin{tabular}{|l|c|}
\hline \multicolumn{2}{|c|}{ Descriptive Statistics for Primary Variables of Interest } \\
\hline Variables & Percentage \\
\hline Independent Variables & \\
\hline Parental Mental Illness & $13.72 \%$ \\
\hline Parental Substance Use & $11.58 \%$ \\
\hline Parental Incarceration & $17.66 \%$ \\
\hline Poverty & $71.60 \%$ \\
\hline & \\
\hline Dependent Variables & $7.16 \%$ \\
\hline School Failure & $41.17 \%$ \\
\hline Criminal Behavior & $8.11 \%$ \\
\hline Arrested & $42.60 \%$ \\
\hline Behavioral Difficulty & $66.59 \%$ \\
\hline Emotional Difficulty & $29.83 \%$ \\
\hline Alcohol Use & $44.99 \%$ \\
\hline Drug Use & \\
\hline
\end{tabular}

Tables 18 and 19 show the correlations among the independent variables and among the dependent variables, respectively. When analyzing the validity of the model proposed in this study it is important to determine that the independent variables are not highly correlated so that each construct can be assumed to be measuring different phenomenon within the sample. Similarly, the presence of high correlation coefficients among the dependent variables dictates that a multivariate analysis is necessary rather than separate univariate analyses 
(Long, 1997). Table 18 illustrates that there is not significant correlation among the independent variables and Table 19 illustrates enough correlation between the dependent variables to justify the use of multivariate analysis techniques.

Table 18

Correlations among Independent Variables (Risk Factors)

\begin{tabular}{|c|c|c|c|c|}
\hline \multicolumn{5}{|c|}{ Correlation Table-Independent Variables (Risk Factors) } \\
\hline & $\begin{array}{c}\text { Parental Mental } \\
\text { IIIness }\end{array}$ & $\begin{array}{c}\text { Parental Substance } \\
\text { Use }\end{array}$ & $\begin{array}{c}\text { Parental } \\
\text { Incarceration }\end{array}$ & Poverty \\
\hline $\begin{array}{c}\text { Parental Mental } \\
\text { IIness }\end{array}$ & 1.0000 & & & \\
\hline $\begin{array}{c}\text { Parental Substance } \\
\text { Use }\end{array}$ & $0.1742^{\star \star \star}$ & 1.0000 & & \\
\hline $\begin{array}{c}\text { Parental } \\
\text { Incarceration }\end{array}$ & 0.0009 & $0.1416^{\star \star \star}$ & 1.0000 & \\
\hline Poverty & -0.0108 & -0.0009 & $0.0526+$ & 1.0000 \\
\hline
\end{tabular}

${ }^{* \star *} p<0.01,{ }^{* *} p<0.05,{ }^{*} p<0.10,+p<0.20$

Table 19

Correlations among Dependent Variables (Child Outcomes)

\begin{tabular}{|c|c|c|c|c|c|c|c|}
\hline \multicolumn{7}{|c|}{ Correlation Table-Dependent Variables } \\
\hline & $\begin{array}{c}\text { School } \\
\text { Failure }\end{array}$ & $\begin{array}{c}\text { Criminal } \\
\text { Behavior }\end{array}$ & Arrested & $\begin{array}{c}\text { Behavioral } \\
\text { Difficulty }\end{array}$ & $\begin{array}{c}\text { Emotional } \\
\text { Difficulty }\end{array}$ & $\begin{array}{c}\text { Alcohol } \\
\text { Use }\end{array}$ & $\begin{array}{c}\text { Drug } \\
\text { Use }\end{array}$ \\
\hline School Failure & $1.0000^{\star \star \star}$ & & & & & & \\
\hline $\begin{array}{c}\text { Criminal } \\
\text { Behavior }\end{array}$ & $0.1052^{\star \star \star}$ & 1.0000 & & & & & \\
\hline Arrested & $0.1046+$ & $0.2203^{\star \star \star}$ & 1.0000 & & & & \\
\hline $\begin{array}{c}\text { Behavior } \\
\text { Difficulty }\end{array}$ & $0.0496^{\star \star \star}$ & $0.2895^{\star \star \star}$ & $0.1485^{\star \star \star}$ & 1.0000 & & & \\
\hline $\begin{array}{c}\text { Emotional } \\
\text { Difficulty }\end{array}$ & $0.1276^{\star \star \star}$ & $0.0801^{\star \star \star}$ & 0.0069 & $0.1119^{\star \star \star}$ & 1.0000 & & \\
\hline Alcohol Use & $0.0718^{\star \star}$ & $0.3520^{\star \star \star}$ & $0.1877^{\star \star \star}$ & $0.2307^{\star \star \star}$ & $0.0674^{\star \star}$ & 1.0000 & \\
\hline Drug Use & $0.0653^{\star}$ & $0.3246^{\star \star \star}$ & $0.1438^{\star \star \star}$ & $0.1988^{\star \star \star}$ & $0.0812^{\star \star \star}$ & $0.7213^{\star \star \star}$ & 1.0000 \\
\hline
\end{tabular}

${ }^{\star \star \star *} p<0.01,{ }^{\star \star} p<0.05,{ }^{*} p<0.10,+p<0.20$ 


\section{Regression Results}

\section{Understanding probit regression.}

Multivariate probit regression was used to examine the impact of four parental risk factors (parental mental illness, parental substance use, parental incarceration and poverty) on seven child outcomes (school failure, crime, being arrested, behavioral difficulties, emotional difficulties, alcohol use, and drug use). Probit regression is a statistical technique used largely within sociological and psychological research because of the prevalence of nominal and ordinal level dependent variables in those fields (Muthen, 1989). Historically, several statistical models have allowed for regression like modeling in situations where there is a preponderance of nominal and ordinal data. The two most popular methods within sociological research are the logit (or logistic) regression and the probit regression. Both models are very similar and many researchers are able to use them interchangeably. Both models are part of a larger class of generalized linear models and both models regress the probability that a given case falls in a specific category of $Y$ (independent variable), on a linear combination of $X$ (dependent) variables. In this way the logit and probit regression are similar to the classical linear regression model in that the slope coefficients tell us the effect of a unit of change in the independent variable (risk) on the probability of the dependent variable (outcome) (Long, 1997). Based on this it follows that when interpreting the coefficients generated by the probit regression model we can understand how a change in the independent variable 
(risk factor) affects the probability that a dependent variable (child outcome) will occur, assuming that all other independent variables stay the same.

Suppose that one outcome were to be modeled as a function of one risk, the univariate probit model would be defined as

$$
\text { Outcome }=\left\{\begin{array}{l}
1 \text { if index }>0 \\
0 \text { otherwise }
\end{array}\right.
$$

There are two possible outcomes, zero and one. If the generated probit index is greater than 0 then the outcome is 1 , otherwise it is coded as 0 (or if the index is less than zero). The probit index is defined using the following equation:

$$
\text { Index }=\mathrm{a}+\mathrm{b}(\text { risk })-\varepsilon
$$

a would be a constant term and $b$ would be the coefficient on the independent variable risk and $\varepsilon$ is an error term. If $\varepsilon$ is normally distributed then the model is called the probit model and the probability of the outcome given the risk is

$$
\text { probability (outcome }=1 \text { | risk })=\Phi(a+b(\text { risk }) \text { ) }
$$

where $\Phi($.$) is the standard cumulative normal probability distribution and$ $a+b$ (risk) is the probit score or index (Ender, 2010). When the cumulative distribution of the error $(\varepsilon)$ is the logistic distribution the model becomes the logit model (Ender, 2010; Long, 1997). As in the case of the linear regression model, $a$ unit change in the risk factor changes the index by $b$ units. This will translate into a change in the probability of the outcome, but the exact magnitude of the change will depend on the value taken by all of the independent variables/risk factors. The variance of the error $(\varepsilon)$ is generally assumed to be equal to one. As a result the index is equivalent to a $Z$ score, a statistic generally familiar to social scientists. A Z score is a standardized score expressed in units of standard deviations from the mean (Garson, 2010; Long, 1997). In this study, 
the index is used to calculate the probability that a child outcome will/will not occur.

To clarify, consider the following hypothetical example where one risk factor (parental incarceration) and one outcome (drug use) are examined. The parameters are chosen by the statistical program so that the likelihood of observing the actual data is the highest possible, also known as the maximum likelihood estimation method (Myung, 2003). If after the estimation of the parameters,

$$
\text { Index }=0.5+\left(0.2{ }^{*} \text { Risk }\right)
$$

where the risk is assumed to be equal to one if a parent is incarcerated and equal to zero otherwise (i.e. not incarcerated) then when the risk is equal to zero, the index would be equal to 0.5 , and similarly when the risk is equal to one, the index would be equal to 0.7 . The index for those children with an incarcerated parent would be 0.2 units higher than the index for those without an incarcerated parent. As a result, the probability of the occurrence of drug use for those with an incarcerated parent would be $(\Phi(0.7)-\Phi(0.5))$ higher than the probability for those without an incarcerated parent. If you consulted a standard normal distribution table you would find that $(\Phi(0.7)-\Phi(0.5))$ is equal to 0.067 which would mean that those children with an incarcerated parent would be $6.7 \%$ more likely to engage in drug use than those without an incarcerated parent.

As discussed earlier, because of the potential correlation among the seven outcome variables in this study a multivariate probit regression is more appropriate. The interpretation of a multivariate probit regression is similar to that already discussed. Additionally, the multivariate probit is preferable to the 
multivariate logit regression because it is more flexible and imposes fewer restrictions on the correlations among the outcomes (Garson, 2010; Long, 1997).

The model used in the current study is represented by the following equations:

- School failure index $=$ constant $+b 11^{*}$ risk1 $+b 12^{*}$ risk2 $+b 13^{*}$ risk3+ b14*risk4 +Error1

- Criminal behavior index $=$ constant $+b 21^{*}$ risk $1+b 22^{*}$ risk2 $+b 23^{*}$ risk $3+$ b24*risk4 + Error2

- Arrest index $=$ constant $+\mathrm{b} 31^{*}$ risk1 $+\mathrm{b} 32^{*}$ risk2 $+\mathrm{b} 33^{\star}$ risk3+ b34*risk4+Error3

- Behavioral difficulty index $=$ constant $+b 41^{*}$ risk1 $+b 42^{*}$ risk2 + b43*risk3+ b44*risk4+Error4

- Emotional difficulty index $=$ constant $+b 51^{*}$ risk1 $+b 52^{*}$ risk2 + b53*risk3+ b54*risk4+Error5

- Alcohol use index $=$ constant $+b 61^{*}$ risk $1+b 62^{*}$ risk2 + b63*risk $3+$ b64*risk4+Error6

- Drug use index $=$ constant $+b 71^{*}$ risk $1+b 72^{*}$ risk2 $+b 73^{*}$ risk3 $+b 74^{\star}$ risk4 + Error7

The error terms when taken together are assumed to follow a multivariate normal distribution. Looking at the first equation, one can see that $b 11$ represents the change in the school failure (outcome 1) index caused by a one unit change in risk 1 (parental mental illness) and b12 represent the change in the school failure index caused by a one unit change in risk 2 (parental substance use) and b13 
represents the change in the school failure index caused by one unit change in risk 3 (parental incarceration), and $b 14$ represent the change caused by a one unit change in risk 4 (poverty). The coefficients of the other equations (outcomes) can be interpreted similarly.

To understand the results of the multivariate probit regression it is helpful to examine the coefficient, standard error and $p$-value for each outcome. The coefficient shows the relationship between the probit index that represents the outcomes (as described earlier in this section) and the different risks examined in the model. When examining the coefficient table (Table 20) the most helpful information is the direction of the coefficient (either positive or negative) and whether the coefficient is statistically significant. Coefficients from the probit model can be difficult to interpret, however, because they measure the change in the unobservable indices associated with a one unit change in the corresponding risk factors (irving.vassar.edu/faculty/wl/Econ210/LPMf02.pdf). For this reason it is helpful to also examine the effects of each risk factor on the outcome probabilities for each dependent variable in order to more easily interpret the probit results. Tables that present the probit regression results and the predicted probability of each dependent variable were examined for clarity.

The results of the probit regression are reported in Table 20. For example, in the first column, the school performance index appears to be related only to parental mental illness as indicated by a significant $(p<0.05)$ finding on that risk only. The standard error for the coefficients (reported in parenthesis) provides an idea of the variability of the estimated coefficients. For example, a 
smaller standard error (closer to zero) relative to the coefficient indicates possible significance. For each equation the constant is the value of the index when all of the risks are equal to zero.

For clarity, consider the coefficient for school failure on the first independent variable, parental mental illness. The coefficient is positive indicating that as parental mental illness increases so does school failure. This finding is significant $(p<0.05)$ indicating that the independent variable parental mental illness was found to have a significant impact on child school failure. The coefficients themselves are an indication of the amount of effect the independent variable will have on the probit index discussed earlier. The probit index is then used to predict the probability of an outcome occurring, an easier and more straight forward finding to interpret. Those predicted probabilities will be reported later in this chapter in Tables 23-29.

Table 20

\section{Probit Regression Results}

\begin{tabular}{|c|c|c|c|c|c|c|c|}
\hline & \multicolumn{7}{|c|}{ Dependent Variables } \\
\hline & $\begin{array}{l}\text { School } \\
\text { Failure }\end{array}$ & Crime & Arrested & Behavioral & Emotional & Alcohol & Drugs \\
\hline \multicolumn{8}{|l|}{ IV } \\
\hline \begin{tabular}{|c|} 
Parental \\
Mental IIIness
\end{tabular} & $\begin{array}{l}0.3552^{* *} \\
(0.1730)\end{array}$ & $\begin{array}{l}0.2124+ \\
(0.1291)\end{array}$ & $\begin{array}{l}0.5 \varepsilon \\
10 .\end{array}$ & $7^{* *}$ & $\begin{array}{r}0.0 \\
(0.1\end{array}$ & $\begin{array}{c}0.1654 \\
(0.1304)\end{array}$ & $\begin{array}{l}69 \\
50)\end{array}$ \\
\hline \begin{tabular}{c|} 
Parental \\
Substance Use
\end{tabular} & $\begin{array}{c}0.0132 \\
(0.2093)\end{array}$ & $\begin{array}{l}0.4345^{\star \star \star \star} \\
(0.1426)\end{array}$ & $\begin{array}{l}0.2532+ \\
(0.1764)\end{array}$ & $\begin{array}{c}-0.0201 \\
(0.1401)\end{array}$ & $\begin{array}{c}-0.1430 \\
(0.1412)\end{array}$ & $\begin{array}{c}0.1396 \\
(0.1422)\end{array}$ & $\begin{array}{c}0.1440 \\
(0.1338)\end{array}$ \\
\hline $\begin{array}{c}\text { Parental } \\
\text { Incarceration }\end{array}$ & $\begin{array}{l}-0.1381 \\
(0.1847)\end{array}$ & $\begin{array}{l}0.3806^{\star \star \star \star} \\
(0.1172)\end{array}$ & $\begin{array}{l}0.4417^{\star \star \star} \\
(0.1513)\end{array}$ & $\begin{array}{l}0.1943^{*} \\
(0.1147)\end{array}$ & $\begin{array}{c}0.0351 \\
(0.1185)\end{array}$ & $\begin{array}{l}0.2087^{*} \\
(0.1190)\end{array}$ & $\begin{array}{l}0.3076^{* * *} \\
(0.1103)\end{array}$ \\
\hline Poverty & $\begin{array}{c}0.2381 \\
(0.1570)\end{array}$ & $\begin{array}{c}-0.1054 \\
(0.0974) \\
\end{array}$ & $\begin{array}{c}-0.0010 \\
(0.1432)\end{array}$ & $\begin{array}{l}-0.0578 \\
(0.0963)\end{array}$ & $\begin{array}{l}0.1635^{*} \\
(0.0978)\end{array}$ & $\begin{array}{c}-0.2563^{\star \star \star \star} \\
(0.0982)\end{array}$ & $\begin{array}{c}-0.1973^{\star *} \\
(0.0912) \\
\end{array}$ \\
\hline Constant & $\begin{array}{c}-1.6825^{* * \star} \\
(0.1439)\end{array}$ & $\begin{array}{c}-0.2917^{* \star \star \star} \\
(0.0867)\end{array}$ & $\begin{array}{c}-1.6483^{\star \star \star} \\
(0.1333)\end{array}$ & $\begin{array}{c}-0.2243^{\star *} \\
(0.0857)\end{array}$ & $\begin{array}{c}0.3177^{\star \star \star} \\
(0.0865)\end{array}$ & $\begin{array}{c}-0.4197^{\star k+\hbar} \\
(-.0861)\end{array}$ & $\begin{array}{l}-0.0086 \\
(0.0820)\end{array}$ \\
\hline
\end{tabular}

${ }^{* * *} p<0.01,{ }^{* *} p<0.05,{ }^{*} p<0.10,+p<0.20$ 
All independent variables were found to have a significant impact (at least $p<0.05$ ) on one or more dependent variables. Parental mental illness and parental incarceration were both found to have a significant impact on three different dependent variables. Both parental mental illness and parental incarceration showed a significant impact $(p<0.01)$ on whether a youth gets arrested. Additionally, parental incarceration was found to impact youth participation in crime and drug use $(p<0.01)$. Parental mental illness impacted school failure and behavioral difficulties $(p<0.05)$. Parental substance use was found to significantly impact youth crime $(p<0.01)$ and poverty was found to impact both drug use $(p<0.05)$ and alcohol use $(p<0.01)$. Notice that the coefficients for drug use and alcohol use, when poverty is the risk, are actually negative. This indicates that the presence of poverty actually decreases the probability that a child in this sample would use drug or alcohol.

The first probit model examined the impact of individual risks when other risks known to impact child outcomes were controlled for by the model. In order to determine the impact of accumulated risk, a second probit regression was conducted using a risk index score. This index score simply counts the number of risk factors that are present in a child's life and assigns a value between zero and four. If a child has no risks s/he will be scored as a zero. If $s / h e$ has all four risks the score will be four and so on. Table 21 presents the descriptive statistics for the risk index variable, including frequencies and mean score. 


\section{Table 21}

Descriptive Statistics of Risk Index Score

\begin{tabular}{|c|c|c|c|}
\hline $\begin{array}{c}\text { Risk Index } \\
\text { Score }\end{array}$ & Frequency & $\begin{array}{c}\text { Percentage of } \\
\text { Sample }\end{array}$ & Mean Score \\
\hline 0 & 161 & $19.01 \%$ & 1.148 \\
\hline 1 & 458 & $54.07 \%$ & (Standard Error= \\
\hline 2 & 177 & $20.90 \%$ & $0.0279)$ \\
\hline 3 & 44 & $5.19 \%$ & \\
\hline 4 & 7 & $0.83 \%$ & \\
\hline
\end{tabular}

\section{Table 22}

\section{Probit Regression using Risk Index Score}

\begin{tabular}{|c|c|c|c|c|c|c|c|}
\hline & \multicolumn{7}{|c|}{ Dependent Variables } \\
\hline & $\begin{array}{c}\text { School } \\
\text { Failure }\end{array}$ & Crime & Arrested & Behavioral & Emotional & Alcohol & Drugs \\
\hline IV & & & & & & & \\
\hline Risk Index & $0.1183+$ & $0.1979^{\star \star \star}$ & $0.3059^{\star \star \star}$ & $0.0955^{\star}$ & 0.0478 & 0.0357 & 0.0577 \\
$(0-4)$ & $(0.0774)$ & $(0.0549)$ & $(0.0732)$ & $(0.0536)$ & $(0.0556)$ & $(0.0556)$ & $(0.0532)$ \\
\hline Constant & $-1.6068^{\star \star \star}$ & $-0.4465^{* \star \star}$ & $-1.7947^{\star \star \star}$ & $-0.2978^{* \star \star}$ & $-1.7317^{* \star \star}$ & $-0.5612^{\star \star \star}$ & $-0.1354^{*}$ \\
& $(0.1160)$ & $(0.0768)$ & $(0.1197)$ & $(0.0755)$ & $(0.1324)$ & $(0.0786)$ & $(0.0732)$ \\
\hline
\end{tabular}

${ }^{\star * *} p<0.01,{ }^{* *} p<0.05,{ }^{*} p<0.10,+p<0.20$

Notice from these findings that a simple accumulation of risk was not found to significantly impact all negative outcomes. The outcomes most impacted by the presence of multiple risk factors were criminal behaviors, being arrested, and behavioral difficulties. School failure approached significance and that reduced impact may be accounted for by special education programming and other interventions used in the school to address problem behaviors.

\section{Effects and Predicted Outcome Probabilities}

An examination of the effects of changes in the independent variable (risk) on the probabilities of the outcomes allows the researcher to quantify the 
relationship between the risk factors and the outcome probabilities. Effects is defined as the change in predicted probability associated with changes in the independent variable (risk factors) (Anderson \& Newell, 2003). In other words, the sign and magnitude of the effect indicate the impact of the explanatory variable (risk factor) on the probability that the outcome will occur. Tables 23-29 will show the predicted probability for each dependent variable being examined in the study. Each table illustrates the probability that an outcome will occur when there is only one risk factor, no risks factors, 3 risk factors, and when all 4 risk factors are present.

Outcome one-school failure.

Table 23

Predicted Probability of School Failure

\begin{tabular}{|c|c|c|c|}
\hline \multicolumn{2}{|l|}{ Risk } & \multirow{2}{*}{$\begin{array}{l}\text { Effects when all other } \\
\text { risks are absent } \\
0.093=9.3 \% \\
\text { (Parental Mental Illness } \\
\text { Only) }\end{array}$} & \multirow{2}{*}{$\begin{array}{l}\begin{array}{l}\text { Effects when all other } \\
\text { risks are present }\end{array} \\
0.112=11.2 \% \\
\text { (ALL Risks present) }\end{array}$} \\
\hline $\begin{array}{l}\text { Parental Mental } \\
\text { IIIness }\end{array}$ & $\begin{array}{l}\text { Parental Mental } \\
\text { Illness is Present }\end{array}$ & & \\
\hline & $\begin{array}{l}\text { Parental Mental } \\
\text { Illness is Absent }\end{array}$ & $\begin{array}{c}0.046=4.6 \% \\
\text { (NO risk factors present) }\end{array}$ & $\begin{array}{c}0.058=5.8 \% \\
\text { (Other 3 Risks Present) }\end{array}$ \\
\hline \multirow[t]{2}{*}{$\begin{array}{l}\text { Parental Substance } \\
\text { Use }\end{array}$} & $\begin{array}{l}\text { Parental Substance } \\
\text { Use is Present }\end{array}$ & $\begin{array}{c}0.046=4.6 \% \\
\text { (Parental Substance Use } \\
\text { Only) }\end{array}$ & $\begin{array}{c}0.113=11.2 \% \\
\text { (ALL Risks present) }\end{array}$ \\
\hline & $\begin{array}{l}\text { Parental Substance } \\
\text { Use is Absent }\end{array}$ & $\begin{array}{c}0.046=4.6 \% \\
\text { (NO risk factors present) }\end{array}$ & $\begin{array}{c}0.112=11.2 \% \\
\text { (Other } 3 \text { Risks Present) }\end{array}$ \\
\hline \multirow[t]{2}{*}{$\begin{array}{l}\text { Parental } \\
\text { Incarceration }\end{array}$} & $\begin{array}{l}\text { Parental } \\
\text { Incarceration is } \\
\text { Present }\end{array}$ & $\begin{array}{c}0.035=3.5 \% \\
\text { (Parental Incarceration } \\
\text { Only) }\end{array}$ & $\begin{array}{c}0.112=11.2 \% \\
\text { (ALL Risks present) }\end{array}$ \\
\hline & $\begin{array}{l}\text { Parental } \\
\text { Incarceration is } \\
\text { Absent }\end{array}$ & $\begin{array}{c}0.046=4.6 \% \\
\text { (NO risk factors present) }\end{array}$ & $\begin{array}{c}0.139=13.9 \% \\
\text { (Other } 3 \text { Risks Present) }\end{array}$ \\
\hline \multirow[t]{2}{*}{ Poverty } & Poverty is Present & $\begin{array}{c}0.074=7.4 \% \\
\text { (Poverty Only) }\end{array}$ & $\begin{array}{c}0.112=11.2 \% \\
\text { (ALL Risks present) }\end{array}$ \\
\hline & Poverty is Absent & $\begin{array}{c}0.046=4.6 \% \\
\text { (NO risk factors present) }\end{array}$ & $\begin{array}{c}0.073=7.3 \% \\
\text { (Other } 3 \text { Risks Present) }\end{array}$ \\
\hline
\end{tabular}


Notice that the probability of school failure increases from $4.6 \%$ when there are no risks to $11.2 \%$ when all four risk factors were present, indicating a $6.6 \%$ increase in school failure as risks accumulate. Parental mental illness alone increased the probability of this outcome to $9.3 \%$ (a difference of $4.7 \%$ ), but parental substance use contributed to no increased probability of school failure. Parental incarceration and poverty were shown to increase the probability of school failure minimally $(1.1 \%$ and $2.8 \%$ respectively). Even when all risks are present the overall probability of school failure is relatively low (11.2\%) among the children in this sample.

Outcome two-criminal behaviors.

Table 24

Predicted Probability of Criminal Behaviors

\begin{tabular}{|c|c|c|c|}
\hline \multicolumn{2}{|l|}{ Risk } & \multirow{2}{*}{\begin{tabular}{|c|}
$\begin{array}{l}\text { Effects when all other } \\
\text { risks are absent }\end{array}$ \\
$0.461=46.1 \%$ \\
(Parental Mental Illness \\
Only)
\end{tabular}} & \multirow{2}{*}{\begin{tabular}{|c|}
$\begin{array}{l}\text { Effects when all other } \\
\text { risks are present }\end{array}$ \\
$0.742=74.2 \%$ \\
(ALL Risks Present)
\end{tabular}} \\
\hline $\begin{array}{l}\text { Parental Mental } \\
\text { Illness }\end{array}$ & $\begin{array}{l}\text { Parental Mental } \\
\text { lliness is Present }\end{array}$ & & \\
\hline & $\begin{array}{l}\text { Parental Mental } \\
\text { Illness is Absent }\end{array}$ & $\begin{array}{c}0.382=38.2 \% \\
\text { (NO risk factors present) }\end{array}$ & \begin{tabular}{|c|}
$0.673=67.3 \%$ \\
(Other 3 Risks Present) \\
\end{tabular} \\
\hline \multirow[t]{2}{*}{$\begin{array}{l}\text { Parental Substance } \\
\text { Use }\end{array}$} & $\begin{array}{l}\text { Parental Substance } \\
\text { Use is Present }\end{array}$ & $\begin{array}{c}0.559=55.9 \% \\
\text { (Parental Substance Use } \\
\text { Only) }\end{array}$ & $\begin{array}{c}0.742=74.2 \% \\
\text { (ALL Risks Present) }\end{array}$ \\
\hline & $\begin{array}{l}\text { Parental Substance } \\
\text { Use is Absent }\end{array}$ & $\begin{array}{c}0.382=38.2 \% \\
\text { (NO risk factors present) }\end{array}$ & $\begin{array}{c}0.580=58.0 \% \\
\text { (Other } 3 \text { Risks Present) }\end{array}$ \\
\hline \multirow[t]{2}{*}{$\begin{array}{l}\text { Parental } \\
\text { Incarceration }\end{array}$} & $\begin{array}{l}\text { Parental } \\
\text { Incarceration is } \\
\text { Present }\end{array}$ & $\begin{array}{c}0.536=53.6 \% \\
\text { (Parental Incarceration } \\
\text { Only) }\end{array}$ & $\begin{array}{c}0.742=74.2 \% \\
\text { (ALL Risks Present) }\end{array}$ \\
\hline & $\begin{array}{l}\text { Parental } \\
\text { Incarceration is } \\
\text { Absent }\end{array}$ & $\begin{array}{c}0.382=38.2 \% \\
\text { (NO risk factors present) }\end{array}$ & $\begin{array}{c}0.602=60.2 \% \\
\text { (Other 3 Risks Present) }\end{array}$ \\
\hline \multirow[t]{2}{*}{ Poverty } & Poverty is Present & $\begin{array}{c}0.347=34.7 \% \\
\text { (Poverty Only) }\end{array}$ & $\begin{array}{c}0.742=74.2 \% \\
\text { (ALL Risks Present) }\end{array}$ \\
\hline & Poverty is Absent & $\begin{array}{c}0.382=38.2 \% \\
\text { (NO risk factors present) }\end{array}$ & $\begin{array}{c}0.771=77.1 \% \\
\text { (Other 3 Risks Present) }\end{array}$ \\
\hline
\end{tabular}


The probability of criminal behaviors increased from $38.2 \%$ when there are no risks to $74.2 \%$ when all four risk factors were present, indicating a $36 \%$ increase in the probability of criminal behaviors as risks accumulate. All risk factors, except for poverty, were shown to increase the probability of criminal behaviors between $7.9 \%$ (parental mental illness) and $17.7 \%$ (parental substance use). The probability of criminal behaviors is notably higher than school failure among this sample of children. Notice that even when no risk factors were present over $1 / 3$ of the children (38.2\%) reported that they engaged in some kind of criminal behavior.

\section{Outcome threo-being arrested.}

\section{Table 25}

\section{Predicted Probability of being Arrested}

\begin{tabular}{|c|c|c|c|}
\hline \multicolumn{2}{|l|}{ Risk } & \multirow{2}{*}{$\begin{array}{l}\text { Effects when all other } \\
\text { risks are absent } \\
0.140=14.0 \% \\
\text { (Parental Mental Iliness } \\
\text { Only }\end{array}$} & \multirow{2}{*}{$\begin{array}{l}\begin{array}{l}\text { Effects when all other } \\
\text { risks are present }\end{array} \\
0.372=37.2 \% \\
\text { (ALL Risks Present) }\end{array}$} \\
\hline $\begin{array}{l}\text { Parental Mental } \\
\text { Illness }\end{array}$ & $\begin{array}{l}\text { Parental Mental } \\
\text { Illness is Present }\end{array}$ & & \\
\hline & $\begin{array}{l}\text { Parental Mental } \\
\text { Illness is Absent }\end{array}$ & $\begin{array}{c}0.048=4.8 \% \\
\text { (NO risk factors present) }\end{array}$ & $\begin{array}{c}0.180=18.0 \% \\
\text { (Other } 3 \text { Risks Present) }\end{array}$ \\
\hline \multirow[t]{2}{*}{$\begin{array}{l}\text { Parental Substance } \\
\text { Use }\end{array}$} & $\begin{array}{l}\text { Parental Substance } \\
\text { Use is Present }\end{array}$ & $\begin{array}{c}0.086=8.6 \% \\
\text { (Parental Substance Use } \\
\text { Only) }\end{array}$ & $\begin{array}{c}0.372=37.2 \% \\
\text { (ALL Risks Present) }\end{array}$ \\
\hline & $\begin{array}{l}\text { Parental Substance } \\
\text { Use is Absent }\end{array}$ & $\begin{array}{c}0.048=4.8 \% \\
\text { (NO risk factors present) }\end{array}$ & $\begin{array}{c}0.263=26.3 \% \\
\text { (Other } 3 \text { Risks Present) }\end{array}$ \\
\hline \multirow[t]{2}{*}{$\begin{array}{l}\text { Parental } \\
\text { Incarceration }\end{array}$} & $\begin{array}{l}\text { Parental } \\
\text { Incarceration is } \\
\text { Present }\end{array}$ & $\begin{array}{c}0.107=10.7 \% \\
\text { (Parental Incarceration } \\
\text { Only) }\end{array}$ & $\begin{array}{c}0.372=37.2 \% \\
\text { (ALL Risks Present) }\end{array}$ \\
\hline & $\begin{array}{l}\text { Parental } \\
\text { Incarceration is } \\
\text { Absent }\end{array}$ & $\begin{array}{c}0.048=4.8 \% \\
\text { (NO risk factors present) }\end{array}$ & $\begin{array}{c}0.226=22.6 \% \\
\text { (Other } 3 \text { Risks Present) }\end{array}$ \\
\hline \multirow[t]{2}{*}{ Poverty } & Poverty is Present & $\begin{array}{c}0.050=5.0 \% \\
\text { (Poverty Only) }\end{array}$ & $\begin{array}{c}0.372=37.2 \% \\
\text { (ALL Risks Present) }\end{array}$ \\
\hline & Poverty is Absent & $\begin{array}{c}0.048=4.8 \% \\
\text { (NO risk factors present) }\end{array}$ & $\begin{array}{c}0.363=36.3 \% \\
\text { (Other 3 Risks Present) }\end{array}$ \\
\hline
\end{tabular}


The probability of being arrested increased from $4.8 \%$ when there are no risks to $37.2 \%$ when all four risk factors were present, indicating a $32.4 \%$ increase in the probability of being arrested as risks accumulate. Parental mental illness had the largest impact on the probability, increasing it from $4.8 \%$ to $14 \%$ (an increase of $9.2 \%$ ). Parental substance use and parental incarceration were both found to increase the probability of being arrested by approximately $5 \%$. Poverty was not found to increase the probability of this outcome.

\section{Outcome four-behavioral difficulties.}

Table 26

\section{Predicted Probability of Behavioral Difficulties}

\begin{tabular}{|c|c|c|c|}
\hline \multicolumn{2}{|l|}{ Risk } & \multirow{2}{*}{$\begin{array}{l}\text { Effects when all other } \\
\text { risks are absent } \\
0.535=53.5 \% \\
\text { (Parental Mental IIIness } \\
\text { Only) }\end{array}$} & \multirow{2}{*}{$\begin{array}{l}\begin{array}{l}\text { Effects when all other } \\
\text { risks are present }\end{array} \\
0.599=59.9 \% \\
\text { (ALL Risks Present) }\end{array}$} \\
\hline $\begin{array}{l}\text { Parental Mental } \\
\text { Illness }\end{array}$ & $\begin{array}{l}\text { Parental Mental } \\
\text { Illness is Present }\end{array}$ & & \\
\hline & $\begin{array}{l}\text { Parental Mental } \\
\text { Illness is Absent }\end{array}$ & $\begin{array}{c}0.406=40.6 \% \\
\text { (NO risk factors present) }\end{array}$ & $\begin{array}{c}0.470=47.0 \% \\
\text { (Other } 3 \text { Risks Present) }\end{array}$ \\
\hline \multirow[t]{2}{*}{$\begin{array}{l}\text { Parental Substance } \\
\text { Use }\end{array}$} & $\begin{array}{l}\text { Parental Substance } \\
\text { Use is Present }\end{array}$ & $\begin{array}{c}0.408=40.8 \% \\
\text { (Parental Substance Use } \\
\text { Only) }\end{array}$ & $\begin{array}{c}0.599=59.9 \% \\
\text { (ALL Risks Present) }\end{array}$ \\
\hline & $\begin{array}{l}\text { Parental Substance } \\
\text { Use is Absent }\end{array}$ & $\begin{array}{c}0.406=40.6 \% \\
\text { (NO risk factors present) }\end{array}$ & $\begin{array}{c}0.597=59.7 \% \\
\text { (Other 3 Risks Present) }\end{array}$ \\
\hline \multirow[t]{2}{*}{$\begin{array}{l}\text { Parental } \\
\text { Incarceration }\end{array}$} & $\begin{array}{l}\text { Parental } \\
\text { Incarceration is } \\
\text { Present }\end{array}$ & $\begin{array}{c}0.482=48.2 \% \\
\text { (Parental Incarceration } \\
\text { Only) }\end{array}$ & $\begin{array}{c}0.599=59.9 \% \\
\text { (ALL Risks Present) }\end{array}$ \\
\hline & $\begin{array}{l}\text { Parental } \\
\text { Incarceration is } \\
\text { Absent }\end{array}$ & $\begin{array}{c}0.406=40.6 \% \\
\text { (NO risk factors present) }\end{array}$ & $\begin{array}{c}0.523=52.3 \% \\
\text { (Other 3 Risks Present) }\end{array}$ \\
\hline \multirow[t]{2}{*}{ Poverty } & Poverty is Present & $\begin{array}{c}0.392=39.2 \% \\
\text { (Poverty Only) }\end{array}$ & $\begin{array}{c}0.599=59.9 \% \\
\text { (ALL Risks Present) }\end{array}$ \\
\hline & Poverty is Absent & $\begin{array}{c}0.406=40.6 \% \\
\text { (NO risk factors present) }\end{array}$ & $\begin{array}{c}0.613=61.3 \% \\
\text { (Other } 3 \text { Risks Present) }\end{array}$ \\
\hline
\end{tabular}

The risk of behavioral difficulties increased from $40.6 \%$ when there are no risks to $59.9 \%$ when all four risk factors were present, indicating a $19.3 \%$ 
increase in the probability of behavioral difficulties as risks accumulate. Parental substance use and poverty were not shown to increase the probability of this outcome. Parental mental illness increase the probability by $12.9 \%$ and parental incarceration increased the probability by $7.6 \%$. Notice that even when there were no risks present the probability of behavioral difficulties was high in this sample, $40.6 \%$.

\section{Outcome five-emotional difficulties}

\section{Table 27}

Predicted Probability of Emotional Difficulties

\begin{tabular}{|c|c|c|c|}
\hline \multicolumn{2}{|l|}{ Risk } & \multirow{2}{*}{\begin{tabular}{|c|}
$\begin{array}{c}\text { Effects when all other } \\
\text { risks are absent }\end{array}$ \\
$\begin{array}{c}0.635=63.5 \% \\
\text { (Parental Mental Illness } \\
\text { Only) }\end{array}$ \\
\end{tabular}} & \multirow{2}{*}{\begin{tabular}{|c|}
$\begin{array}{l}\text { Effects when all other } \\
\text { risks are present }\end{array}$ \\
$\begin{array}{c}0.668=66.8 \% \\
\text { (ALL Risks Present) }\end{array}$
\end{tabular}} \\
\hline $\begin{array}{l}\text { Parental Mental } \\
\text { Illiness }\end{array}$ & $\begin{array}{l}\text { Parental Mental } \\
\text { Illness is Present }\end{array}$ & & \\
\hline & $\begin{array}{l}\text { Parental Mental } \\
\text { Illness is Absent }\end{array}$ & $\begin{array}{c}0.622=62.2 \% \\
\text { (NO risk factors present) }\end{array}$ & $\begin{array}{c}0.656=65.6 \% \\
\text { (Other } 3 \text { Risks Present) }\end{array}$ \\
\hline \multirow[t]{2}{*}{$\begin{array}{l}\text { Parental Substance } \\
\text { Use }\end{array}$} & $\begin{array}{l}\text { Parental Substance } \\
\text { Use is Present }\end{array}$ & $\begin{array}{c}0.576=57.6 \% \\
\text { (Parental Substance Use } \\
\text { Only) }\end{array}$ & $\begin{array}{c}0.668=66.8 \% \\
\text { (ALL Risks Present) }\end{array}$ \\
\hline & $\begin{array}{l}\text { Parental Substance } \\
\text { Use is Absent }\end{array}$ & $\begin{array}{c}0.622=62.2 \% \\
\text { (NO risk factors present) }\end{array}$ & $\begin{array}{c}0.710=71.0 \% \\
\text { (Other } 3 \text { Risks Present) }\end{array}$ \\
\hline \multirow[t]{2}{*}{$\begin{array}{l}\text { Parental } \\
\text { Incarceration }\end{array}$} & $\begin{array}{l}\text { Parental } \\
\text { Incarceration is } \\
\text { Present }\end{array}$ & $\begin{array}{c}0.636=63.6 \% \\
\text { (Parental Incarceration } \\
\text { Only) }\end{array}$ & $\begin{array}{c}0.668=66.8 \% \\
\text { (ALL Risks Present) }\end{array}$ \\
\hline & $\begin{array}{l}\text { Parental } \\
\text { Incarceration is } \\
\text { Absent }\end{array}$ & $\begin{array}{c}0.622=62.2 \% \\
\text { (NO risk factors present) }\end{array}$ & $\begin{array}{c}0.655=65.5 \% \\
\text { (Other } 3 \text { Risks Present) }\end{array}$ \\
\hline \multirow[t]{2}{*}{ Poverty } & Poverty is Present & $\begin{array}{c}0.686=68.6 \% \\
\text { (Poverty Only) }\end{array}$ & $\begin{array}{c}0.668=66.8 \% \\
\text { (ALL Risks Present) }\end{array}$ \\
\hline & Poverty is Absent & $\begin{array}{c}0.622=62.2 \% \\
\text { (NO risk factors } \\
\text { present) }\end{array}$ & $\begin{array}{c}0.603=60.3 \% \\
\text { (Other } 3 \text { Risks Present) }\end{array}$ \\
\hline
\end{tabular}

Most notably in this table is the high probability that children in this sample will experience emotional difficulties regardless of risk (approximately 65\%). The 
probability differs by less than $5 \%$ when there are no risk factors or when there are all four risk factors present. Additionally, none of the individual risk factors were shown to significantly impact the probability of this outcome.

\section{Outcome six-alcohol use.}

\section{Table 28}

\section{Predicted Probability of Alcohol Use}

\begin{tabular}{|c|c|c|c|}
\hline \multicolumn{2}{|l|}{ Risk } & \multirow{2}{*}{\begin{tabular}{|c}
$\begin{array}{c}\text { Effects when all other } \\
\text { risks are absent }\end{array}$ \\
$0.389=38.9 \%$ \\
(Parental Mental IIIness \\
Only)
\end{tabular}} & \multirow{2}{*}{$\begin{array}{l}\begin{array}{l}\text { Effects when all other } \\
\text { risks are present }\end{array} \\
0.446=44.6 \% \\
\text { (ALL Risks Present) }\end{array}$} \\
\hline $\begin{array}{l}\text { Parental Mental } \\
\text { Illiness }\end{array}$ & $\begin{array}{l}\text { Parental Mental } \\
\text { IIIness is Present }\end{array}$ & & \\
\hline & $\begin{array}{l}\text { Parental Mental } \\
\text { lilness is Absent }\end{array}$ & $\begin{array}{c}0.331=33.1 \% \\
\text { (NO risk factors present) }\end{array}$ & $\begin{array}{c}0.385=38.5 \% \\
\text { (Other } 3 \text { Risks Present) }\end{array}$ \\
\hline \multirow[t]{2}{*}{$\begin{array}{l}\text { Parental Substance } \\
\text { Use }\end{array}$} & $\begin{array}{l}\text { Parental Substance } \\
\text { Use is Present }\end{array}$ & $\begin{array}{c}0.400=40.0 \% \\
\text { (Parental Substance Use } \\
\text { Only) }\end{array}$ & $\begin{array}{c}0.446=44.6 \% \\
\text { (ALL Risks Present) }\end{array}$ \\
\hline & $\begin{array}{l}\text { Parental Substance } \\
\text { Use is Absent }\end{array}$ & $\begin{array}{c}0.331=33.1 \% \\
\text { (NO risk factors present) }\end{array}$ & $\begin{array}{c}0.374=37.4 \% \\
\text { (Other } 3 \text { Risks Present) }\end{array}$ \\
\hline \multirow[t]{2}{*}{$\begin{array}{l}\text { Parental } \\
\text { Incarceration }\end{array}$} & $\begin{array}{l}\text { Parental } \\
\text { Incarceration is } \\
\text { Present }\end{array}$ & $\begin{array}{c}0.406=40.6 \% \\
\text { (Parental Incarceration } \\
\text { Only) }\end{array}$ & $\begin{array}{c}0.446=44.6 \% \\
\text { (ALL Risks Present) }\end{array}$ \\
\hline & $\begin{array}{l}\text { Parental } \\
\text { Incarceration is } \\
\text { Absent }\end{array}$ & $\begin{array}{c}0.331=33.1 \% \\
\text { (NO risk factors present) }\end{array}$ & $\begin{array}{c}0.368=36.8 \% \\
\text { (Other } 3 \text { Risks Present) }\end{array}$ \\
\hline \multirow[t]{2}{*}{ Poverty } & Poverty is Present & $\begin{array}{c}0.249=24.9 \% \\
\text { (Poverty Only) }\end{array}$ & $\begin{array}{c}0.446=44.6 \% \\
\text { (ALL Risks Present) }\end{array}$ \\
\hline & Poverty is Absent & $\begin{array}{c}0.331=33.1 \% \\
\text { (NO risk factors present) }\end{array}$ & $\begin{array}{c}0.541=54.1 \% \\
\text { (Other } 3 \text { Risks Present) }\end{array}$ \\
\hline
\end{tabular}

The probability of alcohol use increased from $33.1 \%$ when there are no

risks to $44.6 \%$ when all four risk factors were present, indicating a $11.5 \%$ increase in the probability of alcohol use as risks accumulate. Parental mental illness, parental substance use, and parental incarceration were all found to increase the probability by approximately $7 \%$. Notice that poverty was shown to decrease the probability of alcohol use by almost $10 \%$. 


\section{Outcome seven-drug use.}

\section{Table 29}

\section{Predicted Probability of Drug Use}

\begin{tabular}{|c|c|c|c|}
\hline \multicolumn{2}{|l|}{ Risk } & \multirow{2}{*}{$\begin{array}{l}\text { Effects when all other } \\
\text { risks are absent } \\
0.512=51.2 \% \\
\text { (Parental Mental Illness } \\
\text { Only) }\end{array}$} & \multirow{2}{*}{\begin{tabular}{|c}
$\begin{array}{l}\text { Effects when all other } \\
\text { risks are present }\end{array}$ \\
$0.602=60.2 \%$ \\
(ALL Risks Present)
\end{tabular}} \\
\hline $\begin{array}{l}\text { Parental Mental } \\
\text { lliness }\end{array}$ & $\begin{array}{l}\text { Parental Mental } \\
\text { liliness is Present }\end{array}$ & & \\
\hline & $\begin{array}{l}\text { Parental Mental } \\
\text { Illness is Absent }\end{array}$ & $\begin{array}{c}0.491=49.1 \% \\
\text { (NO risk factors present) }\end{array}$ & $\begin{array}{c}0.582=58.2 \% \\
\text { (Other } 3 \text { Risks Present) }\end{array}$ \\
\hline \multirow[t]{2}{*}{$\begin{array}{l}\text { Parental Substance } \\
\text { Use }\end{array}$} & $\begin{array}{l}\text { Parental Substance } \\
\text { Use is Present }\end{array}$ & $\begin{array}{c}0.540=54.0 \% \\
\text { (Parental Substance Use } \\
\text { Only) }\end{array}$ & $\begin{array}{c}0.602=60.2 \% \\
\text { (ALL Risks Present) }\end{array}$ \\
\hline & $\begin{array}{l}\text { Parental Substance } \\
\text { Use is Absent }\end{array}$ & $\begin{array}{c}0.491=49.1 \% \\
\text { (NO risk factors present) }\end{array}$ & $\begin{array}{c}0.554=55.4 \% \\
\text { (Other } 3 \text { Risks Present) }\end{array}$ \\
\hline \multirow[t]{2}{*}{$\begin{array}{l}\text { Parental } \\
\text { Incarceration }\end{array}$} & $\begin{array}{l}\text { Parental } \\
\text { Incarceration is } \\
\text { Present }\end{array}$ & $\begin{array}{c}0.610=61.0 \% \\
\text { (Parental Incarceration } \\
\text { Only) }\end{array}$ & $\begin{array}{c}0.602=60.2 \% \\
\text { (ALL Risks Present) }\end{array}$ \\
\hline & $\begin{array}{l}\text { Parental } \\
\text { Incarceration is } \\
\text { Absent }\end{array}$ & $\begin{array}{c}0.491=49.1 \% \\
\text { (NO risk factors present) }\end{array}$ & $\begin{array}{c}0.483=48.3 \% \\
\text { (Other } 3 \text { Risks Present) }\end{array}$ \\
\hline \multirow[t]{2}{*}{ Poverty } & Poverty is Present & $\begin{array}{c}0.414=41.4 \% \\
\text { (Poverty Only) }\end{array}$ & $\begin{array}{c}0.602=60.2 \% \\
\text { (ALL Risks Present) }\end{array}$ \\
\hline & Poverty is Absent & $\begin{array}{c}0.491=49.1 \% \\
\text { (NO risk factors present) }\end{array}$ & $\begin{array}{c}0.674=67.4 \% \text { (Other } 3 \\
\text { Risks Present) }\end{array}$ \\
\hline
\end{tabular}

The probability of drug use increased from $49.1 \%$ when there are no risks to $60.2 \%$ when all four risk factors were present, indicating a $11.1 \%$ increase in the probability of drug use as risks accumulate. The most notable impact on this probability came from parental incarceration (increase of $11.9 \%$ ). Similar to alcohol use, poverty was shown to decrease the probability of drug use (a decrease of $7.7 \%$ ). Again it is interesting to note that the probability of drug use is very high in this sample regardless of the risk factors and the children have a $50 \%$ chance of using drugs even when no risk factors are present. 


\section{Post-hoc Analyses}

At the proposal defense the following questions were asked:

1. Are there any significant between group differences in the sample?

2. What impact would protective factors have when examining child outcomes and parental risk factors?

In response to these questions two post-hoc analyses were conducted. The first identifies sub-groups in the sample based the presence or absence of the risk factors (independent variables). The second analysis adds several protective factors to the probit regressions conducted to address the main research questions.

Sub-group differences. Given the four risk factors (independent variables: parental mental illness, parental substance use, parental incarceration, and poverty) examined in the present study there were 15 different potential combinations or sub-groups. A frequency analysis was conducted to determine the number of subjects falling into each of the possible sub-groups. Table 30 shows the results of this analysis. The groups ranges from fairly large, with the poverty only sub-group making up $45 \%$ of the sample, to the smallest sub-group, parental incarceration and parental mental illness, which contained only 2 respondents $(0.23 \%$ of the sample). The current research study is interested in examining the relationship between variables (variable centered) as opposed to looking a differences between subgroups that may exist within the sample (person centered). Although it is helpful to look at the frequencies of the group in order to have a broader understanding of the sample it is not possible to 
find any deeper meaning without being guided by a person centered analysis. A person centered analysis would allow for a better examination of these differences in order to better understand the role of specific risk factors and combinations of risk. Possible person centered analyses for future research and ways to look for meaningful patterns between groups will be discussed in the next chapter. 


\section{Table 30}

Frequencies of Sub-groups within the Sample

\begin{tabular}{|c|c|c|c|c|}
\hline \multirow[t]{2}{*}{ Group } & \multicolumn{2}{|c|}{$0=N O$} & \multicolumn{2}{|c|}{$1=$ YES } \\
\hline & Frequency & Percentage & Frequency & Percentage \\
\hline $\begin{array}{c}1 \\
\text { Parental incarceration } \\
\text { only }\end{array}$ & 840 & $97.11 \%$ & 25 & $2.89 \%$ \\
\hline $\begin{array}{c}2 \\
\text { Parental substance } \\
\text { use only }\end{array}$ & 851 & $98.38 \%$ & 14 & $1.62 \%$ \\
\hline $\begin{array}{l}3 \\
\text { Parental mental illness } \\
\text { only }\end{array}$ & 840 & $97.11 \%$ & 25 & $2.89 \%$ \\
\hline $\begin{array}{c}4 \\
\text { Poverty only }\end{array}$ & 471 & $54.45 \%$ & 394 & $45.55 \%$ \\
\hline $\begin{array}{l}5 \\
\text { Parental incarceration } \\
\text { and substance use }\end{array}$ & 859 & $99.31 \%$ & 6 & $0.69 \%$ \\
\hline $\begin{array}{c}6 \\
\text { Parental incarceration } \\
\text { and mental illness }\end{array}$ & 863 & $99.77 \%$ & 2 & $0.23 \%$ \\
\hline $\begin{array}{c}7 \\
\text { Parental incarceration } \\
\text { and poverty }\end{array}$ & 784 & $90.64 \%$ & 81 & $9.36 \%$ \\
\hline $\begin{array}{c}8 \\
\text { Parental substance } \\
\text { use and mental illness }\end{array}$ & 859 & $99.31 \%$ & 6 & $0.69 \%$ \\
\hline $\begin{array}{c}9 \\
\text { Parental substance } \\
\text { use and poverty }\end{array}$ & 834 & $96.42 \%$ & 31 & $3.58 \%$ \\
\hline $\begin{array}{c}10 \\
\text { Parental mental illness } \\
\text { and poverty }\end{array}$ & 814 & $94.10 \%$ & 51 & $5.90 \%$ \\
\hline $\begin{array}{c}11 \\
\text { Parental incarceration, } \\
\text { substance use, mental } \\
\text { illness and poverty }\end{array}$ & 841 & $97.23 \%$ & 24 & $2.77 \%$ \\
\hline $\begin{array}{c}12 \\
\text { Parental incarceration, } \\
\text { substance use and } \\
\text { poverty }\end{array}$ & 848 & $98.03 \%$ & 17 & $1.97 \%$ \\
\hline $\begin{array}{c}13 \\
\text { Parental incarceration, } \\
\text { substance use and } \\
\text { mental illness }\end{array}$ & 863 & $99.77 \%$ & 2 & $0.23 \%$ \\
\hline $\begin{array}{c}14 \\
\text { Parental incarceration, } \\
\text { mental illness and } \\
\text { poverty }\end{array}$ & 855 & $98.84 \%$ & 10 & $1.16 \%$ \\
\hline $\begin{array}{c}15 \\
\text { Parental substance } \\
\text { use, mental illness and } \\
\text { poverty }\end{array}$ & 850 & $98.27 \%$ & 15 & $1.73 \%$ \\
\hline
\end{tabular}


Protective factors. At the request of the committee several protective factors were added to the original probit regression model to determine any impact that they may have on the model. Protective factors have been shown in the literature to protect children from the effects of risk factors in their lives (Knoche, Givens, \& Sheridan, 2007). These factors are often personal characteristics of the children such as self-esteem, ambition, ability to make and keep friends, empathy, etc. (Leon, 2003; Schultz, Tharp-Taylor, Haviland, \& Jaycox, 2009). A number of protective factors were identified and added to the analysis: a positive attitude toward self, a belief that they are able to do things that the child likes being at school, that they find school work interesting, a belief that getting arrested would ruin their future, and a belief that using drugs will lead to trouble. These factors were each addressed in the original data set by asking the children to agree or disagree with the following statements.

1. I have a positive attitude toward myself.

2. I believe that I am able to do things.

3. I like being at school.

4. I find school work interesting.

5. I believe that getting arrested would ruin my future.

6. I believe that using drugs will lead to trouble.

Each variable was then recoded to reflect the presence of the protective factor if the child agreed with the statement (coded as 1) and the absence of the protective factor if they disagreed with the statement (codes as 0 ). The original responses were agree, somewhat agree, somewhat disagree, and disagree. If 
children reported that they agreed or somewhat agreed with the statements they were coded as having the protective factor. If children reported that they disagreed or somewhat disagreed with the statements they were codes as not having the protective factor.

\section{Probit regression results.}

The exact same probit models were run as in the prior analysis, this time with the addition of the six protective factors identified. Results of the probit regression with the protective factors are displayed in Table 31. 


\section{Table 31}

\section{Probit Regression with Protective Factors}

\begin{tabular}{|c|c|c|c|c|c|c|c|}
\hline & \multicolumn{7}{|c|}{ Dependent Variables } \\
\hline & $\begin{array}{l}\text { School } \\
\text { Failure }\end{array}$ & Crime & Arrested & $\begin{array}{c}\text { Behavioral } \\
\text { Difficulty }\end{array}$ & $\begin{array}{l}\text { Emotional } \\
\text { Difficulty }\end{array}$ & $\begin{array}{l}\text { Alcohol } \\
\text { Use }\end{array}$ & $\begin{array}{l}\text { Drug } \\
\text { Use }\end{array}$ \\
\hline IV & & & & & & & \\
\hline \begin{tabular}{|c|} 
Parental \\
Mental IIIness
\end{tabular} & $\begin{array}{c}0.2656 \\
(0.1868)\end{array}$ & $\begin{array}{c}0.1687 \\
(0.1319)\end{array}$ & $(0.1287)$ & $\begin{array}{l}0.2913^{* *} \\
(0.1287)\end{array}$ & $\begin{array}{l}-0.0330 \\
(0.1363)\end{array}$ & $\begin{array}{c}0.1665 \\
(0.1330)\end{array}$ & \begin{tabular}{|c|}
0.1257 \\
$(0.1270)$
\end{tabular} \\
\hline $\begin{array}{l}\text { Parental } \\
\text { Substance } \\
\text { Use }\end{array}$ & $\begin{array}{c}-0.1674 \\
(0.2347)\end{array}$ & \begin{tabular}{|c|}
$0.4767^{* \star \star}$ \\
$(0.1452)$
\end{tabular} & $(0.14$ & ) & $\begin{array}{l}59 \\
15)\end{array}$ & $\begin{array}{c}0.1352 \\
(0.1453)\end{array}$ & $\begin{array}{c}0.1707 \\
(0.1380)\end{array}$ \\
\hline $\begin{array}{r}\text { Parer } \\
\text { Incarce }\end{array}$ & $\begin{array}{l}-0.1 \\
(0.15\end{array}$ & & & & & & $\begin{array}{l}0.1750+ \\
(0.1212)\end{array}$ \\
\hline Poverty & $\begin{array}{l}0.2413+ \\
(0.1668)\end{array}$ & $\begin{array}{c}-0.0930 \\
(0.0997)\end{array}$ & $\begin{array}{c}-0.0231 \\
(0.0985)\end{array}$ & $\begin{array}{l}-0.0231 \\
(0.0985)\end{array}$ & $\begin{array}{c}0.1128 \\
(0.1019)\end{array}$ & $\begin{array}{c}-0.2721^{* \star *} \\
(0.1003)\end{array}$ & $\begin{array}{c}-0.1892^{* \star} \\
(0.0956)\end{array}$ \\
\hline \begin{tabular}{|c|} 
PF1 \\
Positive \\
attitude toward \\
self
\end{tabular} & $\begin{array}{l}-0.1214 \\
(0.1688)\end{array}$ & $\begin{array}{l}8 \\
8)\end{array}$ & $(0.1$ & 8) & $\begin{array}{l}99 \\
12)\end{array}$ & $\begin{array}{l}253 \\
224)\end{array}$ & \begin{tabular}{|c|}
$0.1501+$ \\
0.1100
\end{tabular} \\
\hline $\begin{array}{c}\text { PF2 } \\
\text { Am able to do } \\
\text { things }\end{array}$ & $\begin{array}{c}0.0012 \\
(0.1995)\end{array}$ & $\begin{array}{l}39+ \\
338)\end{array}$ & $(0.1$ & $\begin{array}{l}6 \\
6)\end{array}$ & $\begin{array}{l}1^{* \star \star \star} \\
59)\end{array}$ & $\begin{array}{c}0.0955 \\
(0.1394)\end{array}$ & $\begin{array}{c}0.1539 \\
(0.1262)\end{array}$ \\
\hline \begin{tabular}{|c|} 
PF3 \\
Like being at \\
school
\end{tabular} & $\begin{array}{c}-0.9186^{\star \star \star} \\
(0.2173)\end{array}$ & $\begin{array}{c}-0.2313 \\
(0.2037)\end{array}$ & $\begin{array}{l}-0.1 \\
(0.18\end{array}$ & 17) & $\begin{array}{c}-0.4631^{\star \star} \\
(0.2234)\end{array}$ & $\begin{array}{c}-0.4124^{\star \star} \\
(0.1982)\end{array}$ & $\begin{array}{c}-0.1432 \\
0.1932\end{array}$ \\
\hline $\begin{array}{c}\text { PF4 } \\
\text { Find school } \\
\text { work } \\
\text { interesting }\end{array}$ & $\begin{array}{c}-0.4555^{\star \star \star} \\
(0.1682)\end{array}$ & \begin{tabular}{|c|}
$-0.4688^{\star \star \star \star}$ \\
$(0.1286)$
\end{tabular} & $\begin{array}{c}-0.1668+ \\
(0.1259)\end{array}$ & $\begin{array}{l}3+ \\
9)\end{array}$ & $\begin{array}{l}-0.0840 \\
(0.1345)\end{array}$ & $\begin{array}{l}944+ \\
286)\end{array}$ & $\begin{array}{c}-0.2855^{\star \star} \\
0.1231\end{array}$ \\
\hline \begin{tabular}{|c|} 
PF5 \\
Getting \\
arrested would \\
ruin my future
\end{tabular} & $\begin{array}{l}-0.1335 \\
(0.2217)\end{array}$ & \begin{tabular}{|c|}
$-0.3223^{* *}$ \\
$(0.1529)$
\end{tabular} & $\begin{array}{c}0.0961 \\
(0.1512)\end{array}$ & $\begin{array}{c}0.0961 \\
(0.1512)\end{array}$ & $\begin{array}{c}0.0065 \\
(0.1630)\end{array}$ & $\begin{array}{c}-0.0269 \\
(0.1545)\end{array}$ & $\begin{array}{c}-0.1621 \\
(0.15130\end{array}$ \\
\hline $\begin{array}{c}\text { PF6 } \\
\text { Using drugs } \\
\text { will lead to } \\
\text { trouble }\end{array}$ & $\begin{array}{c}-0.2613 \\
(0.2519)\end{array}$ & $\begin{array}{c}-0.0259 \\
(0.1876)\end{array}$ & $\begin{array}{l}-0.2766+ \\
(0.1827)\end{array}$ & $\begin{array}{l}-0.2766+ \\
(0.1827)\end{array}$ & $\begin{array}{c}-0.45852^{\star \star} \\
(0.2218)\end{array}$ & $\begin{array}{l}-0.3243^{\star} \\
(0.1884)\end{array}$ & \begin{tabular}{|c|}
-0.0525 \\
$(0.1809)$
\end{tabular} \\
\hline Constant & $\begin{array}{l}-0.0161 \\
(0.3869)\end{array}$ & $\begin{array}{c}0.4066 \\
(0.3050)\end{array}$ & $\begin{array}{c}0.0691 \\
(0.2924)\end{array}$ & $\begin{array}{c}0.0691 \\
(0.2924)\end{array}$ & $\begin{array}{l}1.9871^{\star \star \star *} \\
(0.3523)\end{array}$ & $\begin{array}{c}0.2910 \\
(0.3065)\end{array}$ & $\begin{array}{c}0.2939 \\
(0.2984) \\
\end{array}$ \\
\hline
\end{tabular}

${ }^{\star \star *} p<0.01,{ }^{\star \star} p<0.05,{ }^{*} p<0.10,+p<0.20$

The results of this analysis demonstrate that when these variables were

included in the model the impact of several risk factors changed. All of the four original parental characteristics (parental mental illness, parental substance use, 
parental incarceration, and poverty) continue to have a significant impact on at least one dependent variable, but the overall impact is significantly reduced. Parental mental illness is shown to impact behavioral difficulties and whether a youth gets arrested, both are significant at the $p<0.05$ level. Poverty significantly impacts both alcohol use $(p<0.01)$ and drug use $(p<0.05)$. Parental substance use and parental incarceration are both found to have a significant impact on youth crime $(p<0.01)$. Several previously significant findings are found to be no longer significant when protective factors are added to the model, including the impact of parental incarceration on alcohol and drug use and the impact of parental mental illness on school failure. 
Table 32

Probit Regression Using Risk Index and Protective Factors

\begin{tabular}{|c|c|c|c|c|c|c|c|}
\hline & \multicolumn{7}{|c|}{ Dependent Variables } \\
\hline & $\begin{array}{l}\text { School } \\
\text { Failure }\end{array}$ & Crime & Arrested & $\begin{array}{c}\text { Behavioral } \\
\text { Difficulty }\end{array}$ & $\begin{array}{l}\text { Emotional } \\
\text { Difficulty }\end{array}$ & $\begin{array}{c}\text { Alcohol } \\
\text { Use }\end{array}$ & $\begin{array}{l}\text { Drug } \\
\text { Use }\end{array}$ \\
\hline \multicolumn{8}{|l|}{ IV } \\
\hline $\begin{array}{c}\text { Risk Index } \\
(0-4)\end{array}$ & $\begin{array}{c}0.0663 \\
(0.0825)\end{array}$ & $\begin{array}{c}0.1976^{\star \star \star \star} \\
(0.0562)\end{array}$ & $\begin{array}{c}0.3090^{\star * \star} \\
(0.0752)\end{array}$ & $\begin{array}{c}0.0931^{\star} \\
(0.0540)\end{array}$ & $\begin{array}{c}-0.0050 \\
(0.1021)\end{array}$ & $\begin{array}{c}0.0132 \\
(0.0562) \\
\end{array}$ & $\begin{array}{c}0.0418 \\
(0.0547) \\
\end{array}$ \\
\hline $\begin{array}{c}\text { PF1 } \\
\text { Positive } \\
\text { attitude toward } \\
\text { self }\end{array}$ & $\begin{array}{c}-0.1360 \\
(0.1680)\end{array}$ & $\begin{array}{c}0.1137 \\
(0.1170)\end{array}$ & $\begin{array}{c}-0.1871 \\
(0.1577)\end{array}$ & $\begin{array}{l}0.2211^{\star} \\
(0.1155)\end{array}$ & $\begin{array}{c}0.2344 \\
(0.1892)\end{array}$ & $\begin{array}{c}0.1440 \\
(0.1212)\end{array}$ & $\begin{array}{l}0.1660+ \\
(0.1092)\end{array}$ \\
\hline $\begin{array}{c}\text { PF2 } \\
\text { Am able to do } \\
\text { things }\end{array}$ & $\begin{array}{c}-0.0309 \\
(0.1981)\end{array}$ & $\begin{array}{l}0.2180+ \\
(0.1334)\end{array}$ & $\begin{array}{c}-0.1464 \\
(0.1811)\end{array}$ & $\begin{array}{c}-0.0715 \\
(0.1279)\end{array}$ & $\begin{array}{c}0.7759^{\star \star \star \star} \\
(0.1819)\end{array}$ & $\begin{array}{c}0.1395 \\
(0.1382)\end{array}$ & $\begin{array}{l}0.1895+ \\
(0.1252)\end{array}$ \\
\hline $\begin{array}{c}\text { PF3 } \\
\text { Like being at } \\
\text { school }\end{array}$ & $\begin{array}{c}-0.8767^{\star \star \star *} \\
(0.2131)\end{array}$ & $\begin{array}{c}-0.2679+ \\
(0.1996)\end{array}$ & $\begin{array}{c}-0.0571 \\
(0.2546)\end{array}$ & $\begin{array}{c}-0.1140 \\
(0.1896)\end{array}$ & $\begin{array}{c}-0.4729 \\
(0.4731)\end{array}$ & $\begin{array}{c}-0.4334^{\star *} \\
(0.1959)\end{array}$ & \begin{tabular}{|c|}
-0.1681 \\
$(0.1911)$
\end{tabular} \\
\hline $\begin{array}{c}\text { PF4 } \\
\text { Find school } \\
\text { work } \\
\text { interesting }\end{array}$ & $\begin{array}{c}-0.4791^{\star \star \star *} \\
(0.1637)\end{array}$ & $\begin{array}{c}-0.4760^{* * *} \\
(0.1269)\end{array}$ & $\begin{array}{c}-0.2192 \\
(0.1716)\end{array}$ & $\begin{array}{c}-0.1967+ \\
(0.1248)\end{array}$ & $\begin{array}{c}0.1574 \\
(0.2286)\end{array}$ & $\begin{array}{c}-0.2307^{\star} \\
(0.1268)\end{array}$ & $\begin{array}{c}-0.3105^{\star *} \\
(0.1223)\end{array}$ \\
\hline $\begin{array}{c}\text { PF5 } \\
\text { Getting } \\
\text { arrested would } \\
\text { ruin my future }\end{array}$ & $\begin{array}{c}-0.0978 \\
(0.2192)\end{array}$ & $\begin{array}{c}-0.3549^{\star \star} \\
(0.1518)\end{array}$ & $\begin{array}{c}-0.1697 \\
(0.2008)\end{array}$ & $\begin{array}{c}0.0887 \\
(0.1502)\end{array}$ & $\begin{array}{l}0.3411+ \\
(0.2377)\end{array}$ & $\begin{array}{c}-0.0601 \\
(0.1512)\end{array}$ & $\begin{array}{c}-0.1889 \\
(0.1486)\end{array}$ \\
\hline $\begin{array}{c}\text { PF6 } \\
\text { Using drugs } \\
\text { will lead to } \\
\text { trouble }\end{array}$ & $\begin{array}{c}-0.2369 \\
(0.2509)\end{array}$ & $\begin{array}{c}-0.0140 \\
(0.1879)\end{array}$ & $\begin{array}{c}-0.1778 \\
(0.2344)\end{array}$ & $\begin{array}{c}-0.2750+ \\
(0.1830)\end{array}$ & $\begin{array}{c}0.0346 \\
(0.3129)\end{array}$ & $\begin{array}{c}-0.3021+ \\
(0.1889)\end{array}$ & $\begin{array}{c}-0.0395 \\
(0.1815)\end{array}$ \\
\hline Constant & $\begin{array}{c}0.0808 \\
(0.3774)\end{array}$ & $\begin{array}{c}0.2583 \\
(0.3003)\end{array}$ & $\begin{array}{c}-0.9939^{\star \star \star} \\
(0.3872)\end{array}$ & $\begin{array}{c}0.0268 \\
(0.2905)\end{array}$ & $\begin{array}{c}0.9666^{*} \\
(0.5605)\end{array}$ & $\begin{array}{c}0.1590 \\
(0.3030)\end{array}$ & $\begin{array}{c}0.1891 \\
(0.2954)\end{array}$ \\
\hline
\end{tabular}

${ }^{* * *} p<0.01,{ }^{* *} p<0.05,{ }^{*} p<0.10,+p<0.20$

When the probit regression was run using the risk index score (indicating an accumulation of risk) and the identified protective factors it was found that the impact of accumulating risk was not different than that found in the original probit regression without the protective factors. Accumulating risk was found to have a significant impact on criminal behaviors, being arrested, and behavioral difficulties only. 


\section{Effects on outcome probabilities.}

As in the previous analysis, the effects on outcome probabilities allows the researcher to quantify the relationship between the independent variables (in this case both the identified risk factors and protective factors) and the probability that an outcome will occur. Seven outcomes were examined-school failure, criminal behaviors, being arrested, behavioral difficulties, emotional difficulties, alcohol use, and drug use. Because of the combination of risk and protective factors in this analysis it is most helpful to examine the difference in the probability when the risk only is present and when all factors are present. 
Table 33

Predicted Probability of School Failure

\begin{tabular}{|c|c|c|c|}
\hline \multicolumn{2}{|l|}{ Factors } & \multirow{2}{*}{$\begin{array}{l}\text { Effects when all other } \\
\text { factors are absent } \\
0.594=59.4 \% \\
\text { (Parental Mental } \\
\text { Illness Only) }\end{array}$} & \multirow{2}{*}{$\begin{array}{l}\text { Effects when all other factors are } \\
\text { present } \\
\qquad 0.046=4.6 \% \\
\text { (All Factors Present) }\end{array}$} \\
\hline $\begin{array}{l}\text { Parental } \\
\text { Mental Illness }\end{array}$ & $\begin{array}{l}\text { Parental Mental } \\
\text { lliness is Present }\end{array}$ & & \\
\hline & $\begin{array}{l}\text { Parental Mental } \\
\text { Illness is Absent }\end{array}$ & $\begin{array}{c}0.489=48.9 \% \\
\text { (NO factors present) }\end{array}$ & $\begin{array}{c}0.025=2.5 \% \\
\text { (All factors except Parental } \\
\text { Mental Illness present) }\end{array}$ \\
\hline \multirow[t]{2}{*}{$\begin{array}{l}\text { Parental } \\
\text { Substance } \\
\text { Use }\end{array}$} & $\begin{array}{l}\text { Parental } \\
\text { Substance Use is } \\
\text { Present }\end{array}$ & $\begin{array}{c}0.423=42.3 \% \\
\text { (Parental Substance } \\
\text { Use Only) }\end{array}$ & $\begin{array}{c}0.046=4.6 \% \\
\text { (All Factors Present) }\end{array}$ \\
\hline & $\begin{array}{l}\text { Parental } \\
\text { Substance Use is } \\
\text { Absent }\end{array}$ & $\begin{array}{c}0.489=48.9 \% \\
\text { (NO factors present) }\end{array}$ & $\begin{array}{c}0.064=6.4 \% \\
\text { (All factors except Parental } \\
\text { Substance Use present) }\end{array}$ \\
\hline \multirow[t]{2}{*}{$\begin{array}{l}\text { Parental } \\
\text { Incarceration }\end{array}$} & $\begin{array}{l}\text { Parental } \\
\text { Incarceration is } \\
\text { Present }\end{array}$ & $\begin{array}{c}0.439=43.9 \% \\
\text { (Parental } \\
\text { Incarceration Only) }\end{array}$ & $\begin{array}{l}0.046=4.6 \% \\
\text { (All Factors Present) }\end{array}$ \\
\hline & $\begin{array}{l}\text { Parental } \\
\text { Incarceration is } \\
\text { Absent }\end{array}$ & $\begin{array}{c}0.489=48.9 \% \\
\text { (NO factors present) }\end{array}$ & $\begin{array}{c}0.059=5.9 \% \\
\text { (All factors except Parental } \\
\text { Incarceration present) }\end{array}$ \\
\hline \multirow[t]{2}{*}{ Poverty } & Poverty is Present & $\begin{array}{l}0.589=58.9 \% \\
\text { (Poverty Only) }\end{array}$ & $\begin{array}{l}0.046=4.6 \% \\
\text { (All Factors Present) }\end{array}$ \\
\hline & Poverty is Absent & $\begin{array}{c}0.489=48.9 \% \\
\text { (NO factors present) }\end{array}$ & $\begin{array}{c}0.026=2.6 \% \\
\text { (All factors except Poverty } \\
\text { present) }\end{array}$ \\
\hline \multirow[t]{2}{*}{ PF 1} & PF 1 is Present & $\begin{array}{l}0.441=44.1 \% \\
\text { (PF } 1 \text { Only) }\end{array}$ & $\begin{array}{c}0.046=4.6 \% \\
\text { (All Factors Present) }\end{array}$ \\
\hline & PF 1 is Absent & $\begin{array}{c}0.489=48.9 \% \\
\text { (NO factors present) }\end{array}$ & $\begin{array}{c}0.059=5.9 \% \\
\text { (All factors except PF } 1 \text { present) }\end{array}$ \\
\hline \multirow[t]{2}{*}{ PF 2} & PF 2 is Present & $\begin{array}{l}0.488=48.8 \% \\
\text { (PF 2 Only) }\end{array}$ & $\begin{array}{c}0.046=4.6 \% \\
\text { (All Factors Present) }\end{array}$ \\
\hline & PF 2 is Absent & $\begin{array}{c}0.489=48.9 \% \\
\text { (NO factors present) }\end{array}$ & $\begin{array}{c}0.046=4.6 \% \\
\text { (All factors except PF } 2 \text { present) }\end{array}$ \\
\hline \multirow[t]{2}{*}{ PF 3} & PF 3 is Present & $\begin{array}{l}0.173=17.3 \% \\
\text { (PF 3 Only) }\end{array}$ & $\begin{array}{c}0.046=4.6 \% \\
\text { (All Factors Present) }\end{array}$ \\
\hline & PF 3 is Absent & $\begin{array}{c}0.489=48.9 \% \\
\text { (NO factors present) }\end{array}$ & $\begin{array}{c}0.221=22.1 \% \\
\text { (All factors except PF } 3 \text { present) }\end{array}$ \\
\hline \multirow[t]{2}{*}{ PF 4} & PF 4 is Present & $\begin{array}{l}0.318=31.8 \% \\
\text { (PF 4 Only) }\end{array}$ & $\begin{array}{c}0.046=4.6 \% \\
\text { (All Factors Present) }\end{array}$ \\
\hline & PF 4 is Absent & $\begin{array}{c}0.489=48.9 \% \\
\text { (NO factors present) }\end{array}$ & $\begin{array}{c}0.108=10.8 \% \\
\text { (All factors except PF } 4 \text { present) }\end{array}$ \\
\hline \multirow[t]{2}{*}{ PF 5} & PF 5 is Present & $\begin{array}{l}0.434=43.4 \% \\
\text { (PF } 5 \text { Only) }\end{array}$ & $\begin{array}{c}0.046=4.6 \% \\
\text { (All Factors Present) }\end{array}$ \\
\hline & PF 5 is Absent & $\begin{array}{c}0.489=48.9 \% \\
\text { (NO factors present) }\end{array}$ & $\begin{array}{c}0.061=6.1 \% \\
\text { (All factors except PF } 5 \text { present) }\end{array}$ \\
\hline \multirow[t]{2}{*}{ PF 6} & PF 6 is Present & $\begin{array}{c}0.384=38.4 \% \\
\text { (PF } 6 \text { Only) }\end{array}$ & $\begin{array}{c}0.046=4.6 \% \\
\text { (All Factors Present) }\end{array}$ \\
\hline & PF 6 is Absent & $\begin{array}{c}0.488=48.8 \% \\
\text { (NO factors present) }\end{array}$ & $\begin{array}{c}0.078=7.8 \% \\
\text { (All factors except PF } 6 \text { present) }\end{array}$ \\
\hline
\end{tabular}


Table 34

Predicted Probability of Criminal Behavior

\begin{tabular}{|c|c|c|c|}
\hline \multicolumn{2}{|l|}{ Factors } & $\begin{array}{l}\text { Effects when all other } \\
\text { factors are absent }\end{array}$ & $\begin{array}{l}\text { Effects when all other factors are } \\
\text { present }\end{array}$ \\
\hline \multirow[t]{2}{*}{$\begin{array}{l}\text { Parental } \\
\text { Mental Illness }\end{array}$} & $\begin{array}{l}\text { Parental Mental } \\
\text { Illness is Present }\end{array}$ & $\begin{array}{c}0.728=72.8 \% \\
\text { (Parental Mental } \\
\text { Illness Only) }\end{array}$ & $\begin{array}{c}0.696=69.6 \% \\
\text { (All Factors Present) }\end{array}$ \\
\hline & $\begin{array}{l}\text { Parental Mental } \\
\text { Illness is Absent }\end{array}$ & $\begin{array}{c}0.671=67.1 \% \\
\text { (NO factors present) }\end{array}$ & $\begin{array}{c}0.636=63.6 \% \\
\text { (All factors except Parental Mental } \\
\text { Illness present) }\end{array}$ \\
\hline \multirow[t]{2}{*}{$\begin{array}{l}\text { Parental } \\
\text { Substance } \\
\text { Use }\end{array}$} & $\begin{array}{l}\text { Parental } \\
\text { Substance Use is } \\
\text { Present }\end{array}$ & $\begin{array}{c}0.810=81.0 \% \\
\text { (Parental Substance } \\
\text { Use Only) }\end{array}$ & $\begin{array}{c}0.696=69.6 \% \\
\text { (All Factors Present) }\end{array}$ \\
\hline & $\begin{array}{l}\text { Parental } \\
\text { Substance Use is } \\
\text { Absent }\end{array}$ & $\begin{array}{c}0.671=67.1 \% \\
\text { (NO factors present) }\end{array}$ & $\begin{array}{c}0.530=53.0 \% \\
\text { (All factors except Parental } \\
\text { Substance Use present) }\end{array}$ \\
\hline \multirow[t]{2}{*}{$\begin{array}{l}\text { Parental } \\
\text { Incarceration }\end{array}$} & $\begin{array}{l}\text { Parental } \\
\text { Incarceration is } \\
\text { Present }\end{array}$ & $\begin{array}{c}0.797=79.7 \% \\
\text { (Parental } \\
\text { Incarceration Only) }\end{array}$ & $\begin{array}{c}0.696=69.6 \% \\
\text { (All Factors Present) }\end{array}$ \\
\hline & $\begin{array}{l}\text { Parental } \\
\text { Incarceration is } \\
\text { Absent }\end{array}$ & $\begin{array}{c}0.671=67.1 \% \\
\text { (NO factors present) }\end{array}$ & $\begin{array}{c}0.550=55.0 \% \\
\text { (All factors except Parental } \\
\text { Incarceration present) }\end{array}$ \\
\hline \multirow[t]{2}{*}{ Poverty } & $\begin{array}{l}\text { Poverty is } \\
\text { Present }\end{array}$ & $\begin{array}{l}0.635=63.5 \% \\
\text { (Poverty Only) }\end{array}$ & $\begin{array}{c}0.696=69.6 \% \\
\text { (All Factors Present) }\end{array}$ \\
\hline & Poverty is Absent & $\begin{array}{c}0.671=67.1 \% \\
\text { (NO factors present) }\end{array}$ & $\begin{array}{c}0.728=72.8 \% \\
\text { (All factors except Poverty } \\
\text { present) }\end{array}$ \\
\hline \multirow[t]{2}{*}{ PF 1} & PF 1 is Present & $\begin{array}{l}0.704=70.4 \% \\
\text { (PF 1 Only) }\end{array}$ & $\begin{array}{c}0.696=69.6 \% \\
\text { (All Factors Present) }\end{array}$ \\
\hline & PF 1 is Absent & $\begin{array}{c}0.671=67.1 \% \\
\text { (NO factors present) }\end{array}$ & $\begin{array}{c}0.662=66.2 \% \\
\text { (All factors except PF } 1 \text { present) }\end{array}$ \\
\hline \multirow[t]{2}{*}{ PF 2} & PF 2 is Present & $\begin{array}{l}0.729=72.9 \% \\
\text { (PF 2 Only) }\end{array}$ & $\begin{array}{c}0.696=69.6 \% \\
\text { (All Factors Present) }\end{array}$ \\
\hline & PF 2 is Absent & $\begin{array}{c}0.671=67.1 \% \\
\text { (NO factors present) }\end{array}$ & $\begin{array}{c}0.634=63.4 \% \\
\text { (All factors except PF } 2 \text { present) }\end{array}$ \\
\hline \multirow[t]{2}{*}{ PF 3} & PF 3 is Present & $\begin{array}{l}0.574=57.4 \% \\
\text { (PF } 3 \text { Only) }\end{array}$ & $\begin{array}{c}0.696=69.6 \% \\
\text { (All Factors Present) }\end{array}$ \\
\hline & PF 3 is Absent & $\begin{array}{c}0.671=67.1 \% \\
\text { (NO factors present) }\end{array}$ & $\begin{array}{c}0.779=77.9 \% \\
\text { (All factors except PF } 3 \text { present) }\end{array}$ \\
\hline \multirow[t]{2}{*}{ PF 4} & PF 4 is Present & $\begin{array}{c}0.483=48.3 \% \\
\text { (PF } 4 \text { Only) }\end{array}$ & $\begin{array}{c}0.696=69.6 \% \\
\text { (All Factors Present) }\end{array}$ \\
\hline & PF 4 is Absent & $\begin{array}{c}0.671=67.1 \% \\
\text { (NO factors present) }\end{array}$ & $\begin{array}{c}0.841=84.1 \% \\
\text { (All factors except PF } 4 \text { present) }\end{array}$ \\
\hline \multirow[t]{2}{*}{ PF 5} & PF 5 is Present & $\begin{array}{l}0.552=55.2 \% \\
\text { (PF 5 Only) }\end{array}$ & $\begin{array}{c}0.696=69.6 \% \\
\text { (All Factors Present) }\end{array}$ \\
\hline & PF 5 is Absent & $\begin{array}{c}0.671=67.1 \% \\
\text { (NO factors present) }\end{array}$ & $\begin{array}{c}0.795=79.5 \% \\
\text { (All factors except PF } 5 \text { present) }\end{array}$ \\
\hline \multirow[t]{2}{*}{ PF 6} & PF 6 is Present & $\begin{array}{l}0.662=66.2 \% \\
\text { (PF 6 Only) }\end{array}$ & $\begin{array}{c}0.696=69.6 \% \\
\text { (All Factors Present) }\end{array}$ \\
\hline & PF 6 is Absent & $\begin{array}{c}0.671=67.1 \% \\
\text { (NO factors present) }\end{array}$ & $\begin{array}{c}0.704=70.4 \% \\
\text { (All factors except PF } 6 \text { present) }\end{array}$ \\
\hline
\end{tabular}


Table 35

Predicted Probability of Being Arrested

\begin{tabular}{|c|c|c|c|}
\hline \multicolumn{2}{|l|}{ Factors } & \multirow{2}{*}{$\begin{array}{c}\text { Effects when all other } \\
\text { factors are absent } \\
0.351=35.1 \% \\
\text { (Parental Mental Illness } \\
\text { Only) }\end{array}$} & \multirow{2}{*}{$\begin{array}{l}\text { Effects when all other factors } \\
\text { are present } \\
0.300=30.0 \% \\
\text { (All Factors Present) }\end{array}$} \\
\hline $\begin{array}{l}\text { Parental } \\
\text { Mental Illness }\end{array}$ & $\begin{array}{l}\text { Parental Mental } \\
\text { Illness is Present }\end{array}$ & & \\
\hline & $\begin{array}{l}\text { Parental Mental } \\
\text { Illness is Absent }\end{array}$ & $\begin{array}{c}0.171=17.1 \% \\
\text { (NO factors present) }\end{array}$ & $\begin{array}{c}0.137=13.7 \% \\
\text { (All factors except Parental } \\
\text { Mental Illness present) }\end{array}$ \\
\hline \multirow[t]{2}{*}{$\begin{array}{l}\text { Parental } \\
\text { Substance } \\
\text { Use }\end{array}$} & $\begin{array}{l}\text { Parental } \\
\text { Substance Use is } \\
\text { Present }\end{array}$ & $\begin{array}{c}0.259=25.9 \% \\
\text { (Parental Substance } \\
\text { Use Only) }\end{array}$ & $\begin{array}{c}0.300=30.0 \% \\
\text { (All Factors Present) }\end{array}$ \\
\hline & $\begin{array}{l}\text { Parental } \\
\text { Substance Use is } \\
\text { Absent }\end{array}$ & $\begin{array}{c}0.171=17.1 \% \\
\text { (NO factors present) }\end{array}$ & $\begin{array}{c}0.203=20.3 \% \\
\text { (All factors except Parental } \\
\text { Substance Use present) }\end{array}$ \\
\hline \multirow[t]{2}{*}{$\begin{array}{l}\text { Parental } \\
\text { Incarceration }\end{array}$} & $\begin{array}{l}\text { Parental } \\
\text { Incarceration is } \\
\text { Present }\end{array}$ & $\begin{array}{c}0.279=27.9 \% \\
\text { (Parental Incarceration } \\
\text { Only) }\end{array}$ & $\begin{array}{l}0.300=30.0 \% \\
\text { (All Factors Present) }\end{array}$ \\
\hline & $\begin{array}{l}\text { Parental } \\
\text { Incarceration is } \\
\text { Absent }\end{array}$ & $\begin{array}{c}0.171=17.1 \% \\
\text { (NO factors present) }\end{array}$ & $\begin{array}{c}0.187=18.7 \% \\
\text { (All factors except Parental } \\
\text { Incarceration present) }\end{array}$ \\
\hline \multirow[t]{2}{*}{ Poverty } & $\begin{array}{l}\text { Poverty is } \\
\text { Present }\end{array}$ & $\begin{array}{l}0.174=17.4 \% \\
\text { (Poverty Only) }\end{array}$ & $\begin{array}{l}0.300=30.0 \% \\
\text { (All Factors Present) }\end{array}$ \\
\hline & Poverty is Absent & $\begin{array}{c}0.171=17.1 \% \\
\text { (NO factors present) }\end{array}$ & $\begin{array}{c}0.295=29.5 \% \\
\text { (All factors except Poverty } \\
\text { present) }\end{array}$ \\
\hline \multirow[t]{2}{*}{ PF 1} & PF 1 is Present & $\begin{array}{l}0.123=12.3 \% \\
(P F 1 \text { Only) }\end{array}$ & $\begin{array}{c}0.300=30.0 \% \\
\text { (All Factors Present) }\end{array}$ \\
\hline & PF 1 is Absent & $\begin{array}{c}0.171=17.1 \% \\
\text { (NO factors present) }\end{array}$ & $\begin{array}{c}0.376=37.6 \% \\
\text { (All factors except PF } 1 \text { present) }\end{array}$ \\
\hline \multirow[t]{2}{*}{$\overline{\text { PF } 2}$} & PF 2 is Present & $\begin{array}{c}0.146=14.6 \% \\
\text { (PF 2 Only) }\end{array}$ & $\begin{array}{c}0.300=30.0 \% \\
\text { (All Factors Present) }\end{array}$ \\
\hline & PF 2 is Absent & $\begin{array}{c}0.171=17.1 \% \\
\text { (NO factors present) }\end{array}$ & $\begin{array}{c}0.337=33.7 \% \\
\text { (All factors except PF } 2 \text { present) }\end{array}$ \\
\hline \multirow[t]{2}{*}{ PF 3} & PF 3 is Present & $\begin{array}{l}0.158=15.8 \% \\
\text { (PF } 3 \text { Only) }\end{array}$ & $\begin{array}{c}0.300=30.0 \% \\
\text { (All Factors Present) }\end{array}$ \\
\hline & PF 3 is Absent & $\begin{array}{c}0.171=17.1 \% \\
\text { (NO factors present) }\end{array}$ & $\begin{array}{c}0.318=31.8 \% \\
\text { (All factors except PF } 3 \text { present) }\end{array}$ \\
\hline \multirow[t]{2}{*}{ PF 4} & PF 4 is Present & $\begin{array}{l}0.136=13.6 \% \\
\text { (PF } 4 \text { Only) }\end{array}$ & $\begin{array}{c}0.300=30.0 \% \\
\text { (All Factors Present) }\end{array}$ \\
\hline & PF 4 is Absent & $\begin{array}{c}0.171=17.1 \% \\
\text { (NO factors present) }\end{array}$ & $\begin{array}{c}0.352=35.2 \% \\
\text { (All factors except PF } 4 \text { present) }\end{array}$ \\
\hline \multirow[t]{2}{*}{ PF 5} & PF 5 is Present & $\begin{array}{l}0.134=13.4 \% \\
\text { (PF 5 Only) }\end{array}$ & $\begin{array}{l}0.300=30.0 \% \\
\text { (All Factors Present) }\end{array}$ \\
\hline & PF 5 is Absent & $\begin{array}{c}0.171=17.1 \% \\
\text { (NO factors present) }\end{array}$ & $\begin{array}{c}0.357=35.7 \% \\
\text { (All factors except PF } 5 \text { present) }\end{array}$ \\
\hline \multirow[t]{2}{*}{ PF 6} & PF 6 is Present & $\begin{array}{l}0.132=13.2 \% \\
\text { (PF } 6 \text { Only) }\end{array}$ & $\begin{array}{l}0.300=30.0 \% \\
\text { (All Factors Present) }\end{array}$ \\
\hline & PF 6 is Absent & $\begin{array}{c}0.171=17.1 \% \\
\text { (NO factors present) }\end{array}$ & $\begin{array}{c}0.359=35.9 \% \\
\text { (All factors except PF } 6 \text { present) }\end{array}$ \\
\hline
\end{tabular}


Table 36

Predicted Probability of Behavioral Difficulty

\begin{tabular}{|c|c|c|c|}
\hline \multicolumn{2}{|l|}{ Factors } & $\begin{array}{l}\text { Effects when all } \\
\text { other factors are } \\
\text { absent }\end{array}$ & $\begin{array}{l}\text { Effects when all other factors are } \\
\text { present }\end{array}$ \\
\hline \multirow[t]{2}{*}{$\begin{array}{l}\text { Parental } \\
\text { Mental IIIness }\end{array}$} & $\begin{array}{l}\text { Parental Mental } \\
\text { Illiness is } \\
\text { Present }\end{array}$ & $\begin{array}{c}0.629=62.9 \% \\
\text { (Parental Mental } \\
\text { Illness Only) }\end{array}$ & $\begin{array}{c}0.565=56.5 \% \\
\text { (All Factors Present) }\end{array}$ \\
\hline & $\begin{array}{l}\text { Parental Mental } \\
\text { Illness is } \\
\text { Absent }\end{array}$ & $\begin{array}{c}0.516=51.6 \% \\
\text { (NO factors present) }\end{array}$ & $\begin{array}{c}0.451=45.1 \% \\
\text { (All factors except Parental Mental } \\
\text { Illness present) }\end{array}$ \\
\hline \multirow[t]{2}{*}{$\begin{array}{l}\text { Parental } \\
\text { Substance } \\
\text { Use }\end{array}$} & $\begin{array}{l}\text { Parental } \\
\text { Substance Use } \\
\text { is Present }\end{array}$ & $\begin{array}{c}0.519=51.9 \% \\
\text { (Parental Substance } \\
\text { Use Only) }\end{array}$ & $\begin{array}{c}0.565=56.5 \% \\
\text { (All Factors Present) }\end{array}$ \\
\hline & $\begin{array}{l}\text { Parental } \\
\text { Substance Use } \\
\text { is Absent }\end{array}$ & $\begin{array}{c}0.516=51.6 \% \\
\text { (NO factors present) }\end{array}$ & $\begin{array}{c}0.562=56.2 \% \\
\text { (All factors except Parental } \\
\text { Substance Use present) }\end{array}$ \\
\hline \multirow[t]{2}{*}{$\begin{array}{l}\text { Parental } \\
\text { Incarceration }\end{array}$} & $\begin{array}{l}\text { Parental } \\
\text { Incarceration is } \\
\text { Present }\end{array}$ & $\begin{array}{c}0.575=57.5 \% \\
\text { (Parental } \\
\text { Incarceration Only) }\end{array}$ & $\begin{array}{c}0.565=56.5 \% \\
\text { (All Factors Present) }\end{array}$ \\
\hline & $\begin{array}{l}\text { Parental } \\
\text { Incarceration is } \\
\text { Absent }\end{array}$ & $\begin{array}{c}0.516=51.6 \% \\
\text { (NO factors present) }\end{array}$ & $\begin{array}{l}\quad 0.506=50.6 \% \\
\text { (All factors except Parental } \\
\text { Incarceration present) }\end{array}$ \\
\hline \multirow[t]{2}{*}{ Poverty } & $\begin{array}{l}\text { Poverty is } \\
\text { Present }\end{array}$ & $\begin{array}{l}0.504=50.4 \% \\
\text { (Poverty Only) }\end{array}$ & $\begin{array}{l}0.565=56.5 \% \\
\text { (All Factors Present) }\end{array}$ \\
\hline & $\begin{array}{l}\text { Poverty is } \\
\text { Absent }\end{array}$ & $\begin{array}{c}0.516=51.6 \% \\
\text { (NO factors present) } \\
\end{array}$ & $\begin{array}{c}0.577=57.7 \% \\
\text { (All factors except Poverty present) }\end{array}$ \\
\hline \multirow[t]{2}{*}{ PF 1} & PF 1 is Present & $\begin{array}{l}0.604=60.4 \% \\
\text { (PF 1 Only) }\end{array}$ & $\begin{array}{c}0.565=56.5 \% \\
\text { (All Factors Present) }\end{array}$ \\
\hline & $\mathrm{PF} 1$ is Absent & $\begin{array}{c}0.516=51.6 \% \\
\text { (NO factors present) }\end{array}$ & $\begin{array}{c}0.476=47.6 \% \\
\text { (All factors except PF } 1 \text { present) }\end{array}$ \\
\hline \multirow[t]{2}{*}{ PF 2} & PF 2 is Present & $\begin{array}{l}0.494=49.4 \% \\
\text { (PF 2 Only) }\end{array}$ & $\begin{array}{c}0.565=56.5 \% \\
\text { (All Factors Present) }\end{array}$ \\
\hline & PF 2 is Absent & $\begin{array}{c}0.516=51.6 \% \\
\text { (NO factors present) }\end{array}$ & $\begin{array}{c}0.587=58.7 \% \\
\text { (All factors except PF } 2 \text { present) }\end{array}$ \\
\hline \multirow[t]{2}{*}{ PF 3} & PF 3 is Present & $\begin{array}{l}0.473=47.3 \% \\
\text { (PF 3 Only) }\end{array}$ & $\begin{array}{c}0.565=56.5 \% \\
\text { (All Factors Present) }\end{array}$ \\
\hline & PF 3 is Absent & $\begin{array}{c}0.516=51.6 \% \\
\text { (NO factors present) }\end{array}$ & $\begin{array}{c}0.607=60.7 \% \\
\text { (All factors except PF } 3 \text { present) }\end{array}$ \\
\hline \multirow[t]{2}{*}{ PF 4} & PF 4 is Present & $\begin{array}{l}0.445=44.5 \% \\
\text { (PF } 4 \text { Only) }\end{array}$ & $\begin{array}{c}0.565=56.5 \% \\
\text { (All Factors Present) }\end{array}$ \\
\hline & PF 4 is Absent & $\begin{array}{c}0.516=51.6 \% \\
\text { (NO factors present) }\end{array}$ & $\begin{array}{c}0.634=63.4 \% \\
\text { (All factors except PF } 4 \text { present) }\end{array}$ \\
\hline \multirow[t]{2}{*}{ PF 5} & PF 5 is Present & $\begin{array}{l}0.554=55.4 \% \\
\text { (PF } 5 \text { Only) }\end{array}$ & $\begin{array}{c}0.565=56.5 \% \\
\text { (All Factors Present) }\end{array}$ \\
\hline & PF 5 is Absent & $\begin{array}{c}0.516=51.6 \% \\
\text { (NO factors present) }\end{array}$ & $\begin{array}{c}0.527=52.7 \% \\
\text { (All factors except PF } 5 \text { present) }\end{array}$ \\
\hline \multirow[t]{2}{*}{ PF 6} & PF 6 is Present & $\begin{array}{l}0.409=40.9 \% \\
\text { (PF } 6 \text { Only) }\end{array}$ & $\begin{array}{c}0.565=56.5 \% \\
\text { (All Factors Present) }\end{array}$ \\
\hline & PF 6 is Absent & $\begin{array}{c}0.516=51.6 \% \\
\text { (NO factors present) }\end{array}$ & $\begin{array}{c}0.668=66.8 \% \\
\text { (All factors except PF } 6 \text { present) }\end{array}$ \\
\hline
\end{tabular}


Table 37

Predicted Probability of Emotional Difficulty

\begin{tabular}{|c|c|c|c|}
\hline \multicolumn{2}{|l|}{ Factors } & $\begin{array}{l}\text { Effects when all other } \\
\text { factors are absent }\end{array}$ & $\begin{array}{l}\text { Effects when all other factors are } \\
\text { present }\end{array}$ \\
\hline \multirow[t]{2}{*}{$\begin{array}{l}\text { Parental } \\
\text { Mental Illness }\end{array}$} & $\begin{array}{l}\text { Parental Mental } \\
\text { IIIness is } \\
\text { Present }\end{array}$ & $\begin{array}{c}0.976=97.6 \% \\
\text { (Parental Mental IIIness } \\
\text { Only) }\end{array}$ & $\begin{array}{c}0.591=59.1 \% \\
\text { (All Factors Present) }\end{array}$ \\
\hline & $\begin{array}{l}\text { Parental Mental } \\
\text { lliness is } \\
\text { Absent }\end{array}$ & $\begin{array}{c}0.976=97.6 \% \\
\text { (NO factors present) }\end{array}$ & $\begin{array}{c}0.592=59.2 \% \\
\text { (All factors except Parental Mental } \\
\text { IIIness present) }\end{array}$ \\
\hline \multirow[t]{2}{*}{$\begin{array}{l}\text { Parental } \\
\text { Substance } \\
\text { Use }\end{array}$} & $\begin{array}{l}\text { Parental } \\
\text { Substance Use } \\
\text { is Present }\end{array}$ & $\begin{array}{c}0.969=96.9 \% \\
\text { (Parental Substance } \\
\text { Use Only) }\end{array}$ & $\begin{array}{c}0.591=59.1 \% \\
\text { (All Factors Present) }\end{array}$ \\
\hline & $\begin{array}{l}\text { Parental } \\
\text { Substance Use } \\
\text { is Absent }\end{array}$ & $\begin{array}{c}0.976=97.6 \% \\
\text { (NO factors present) }\end{array}$ & $\begin{array}{c}0.636=63.6 \% \\
\text { (All factors except Parental } \\
\text { Substance Use present) }\end{array}$ \\
\hline \multirow[t]{2}{*}{$\begin{array}{l}\text { Parental } \\
\text { Incarceration }\end{array}$} & $\begin{array}{l}\text { Parental } \\
\text { Incarceration is } \\
\text { Present }\end{array}$ & $\begin{array}{c}0.978=97.8 \% \\
\text { (Parental Incarceration } \\
\text { Only) } \\
\end{array}$ & $\begin{array}{c}0.591=59.1 \% \\
\text { (All Factors Present) }\end{array}$ \\
\hline & $\begin{array}{l}\text { Parental } \\
\text { Incarceration is } \\
\text { Absent }\end{array}$ & $\begin{array}{c}0.976=97.6 \% \\
\text { (NO factors present) }\end{array}$ & $\begin{array}{c}0.580=58.0 \% \\
\text { (All factors except Parental } \\
\text { Incarceration present) }\end{array}$ \\
\hline \multirow[t]{2}{*}{ Poverty } & $\begin{array}{l}\text { Poverty is } \\
\text { Present }\end{array}$ & $\begin{array}{l}0.982=98.2 \% \\
\text { (Poverty Only) }\end{array}$ & $\begin{array}{c}0.591=59.1 \% \\
\text { (All Factors Present) }\end{array}$ \\
\hline & $\begin{array}{l}\text { Poverty is } \\
\text { Absent }\end{array}$ & $\begin{array}{c}0.976=97.6 \% \\
\text { (NO factors present) }\end{array}$ & $\begin{array}{c}0.547=54.7 \% \\
\text { (All factors except Poverty } \\
\text { present) }\end{array}$ \\
\hline \multirow[t]{2}{*}{ PF 1 } & PF 1 is Present & $\begin{array}{c}0.975=97.5 \% \\
\text { (PF 1 Only) }\end{array}$ & $\begin{array}{c}0.591=59.1 \% \\
\text { (All Factors Present) }\end{array}$ \\
\hline & $\mathrm{PF} 1$ is Absent & $\begin{array}{c}0.976=97.6 \% \\
\text { (NO factors present) }\end{array}$ & $\begin{array}{c}0.602=60.2 \% \\
\text { (All factors except PF 1 present) }\end{array}$ \\
\hline \multirow[t]{2}{*}{ PF 2} & PF 2 is Present & $\begin{array}{l}0.897=89.7 \% \\
\text { (PF } 2 \text { Only) }\end{array}$ & $\begin{array}{c}0.591=59.1 \% \\
\text { (All Factors Present) }\end{array}$ \\
\hline & PF 2 is Absent & $\begin{array}{c}0.976=97.6 \% \\
\text { (NO factors present) }\end{array}$ & $\begin{array}{c}0.829=82.9 \% \\
\text { (All factors except PF } 2 \text { present) }\end{array}$ \\
\hline \multirow[t]{2}{*}{ PF 3} & PF 3 is Present & $\begin{array}{l}0.936=93.6 \% \\
\text { (PF } 3 \text { Only) }\end{array}$ & $\begin{array}{c}0.591=59.1 \% \\
\text { (All Factors Present) }\end{array}$ \\
\hline & $\mathrm{PF} 3$ is Absent & $\begin{array}{c}0.976=97.6 \% \\
\text { (NO factors present) }\end{array}$ & $\begin{array}{c}0.756=75.6 \% \\
\text { (All factors except PF } 3 \text { present) }\end{array}$ \\
\hline \multirow[t]{2}{*}{ PF 4} & PF 4 is Present & $\begin{array}{c}0.971=97.1 \% \\
\text { (PF 4 Only) }\end{array}$ & $\begin{array}{c}0.591=59.1 \% \\
\text { (All Factors Present) }\end{array}$ \\
\hline & $\mathrm{PF} 4$ is Absent & $\begin{array}{c}0.976=97.6 \% \\
\text { (NO factors present) }\end{array}$ & $\begin{array}{c}0.623=62.3 \% \\
\text { (All factors except PF } 4 \text { present) }\end{array}$ \\
\hline \multirow[t]{2}{*}{ PF 5} & PF 5 is Present & $\begin{array}{l}0.977=97.7 \% \\
\text { (PF 5 Only) }\end{array}$ & $\begin{array}{l}0.591=59.1 \% \\
\text { (All Factors Present) }\end{array}$ \\
\hline & $\mathrm{PF} 5$ is Absent & $\begin{array}{c}0.976=97.6 \% \\
\text { (NO factors present) }\end{array}$ & $\begin{array}{c}0.588=58.8 \% \\
\text { (All factors except PF } 5 \text { present) }\end{array}$ \\
\hline \multirow[t]{2}{*}{ PF 6} & PF 6 is Present & $\begin{array}{l}0.933=93.3 \% \\
\text { (PF 6 Only) }\end{array}$ & $\begin{array}{c}0.591=59.1 \% \\
\text { (All Factors Present) }\end{array}$ \\
\hline & PF 6 is Absent & $\begin{array}{c}0.976=97.6 \% \\
\text { (NO factors present) }\end{array}$ & $\begin{array}{c}0.762=76.2 \% \\
\text { (All factors except PF } 6 \text { present) }\end{array}$ \\
\hline
\end{tabular}




\section{Table 38}

\section{Predicted Probability of Alcohol Use}

\begin{tabular}{|c|c|c|c|}
\hline \multicolumn{2}{|l|}{ Factors } & $\begin{array}{l}\text { Effects when all other } \\
\text { factors are absent }\end{array}$ & $\begin{array}{l}\text { Effects when all other factors are } \\
\text { present }\end{array}$ \\
\hline \multirow[t]{2}{*}{$\begin{array}{l}\text { Parental } \\
\text { Mental Illness }\end{array}$} & $\begin{array}{l}\text { Parental Mental } \\
\text { Illness is } \\
\text { Present }\end{array}$ & $\begin{array}{c}0.622=62.2 \% \\
\text { (Parental Mental } \\
\text { Illness Only) }\end{array}$ & $\begin{array}{c}0.398=39.8 \% \\
\text { (All Factors Present) }\end{array}$ \\
\hline & $\begin{array}{l}\text { Parental Mental } \\
\text { Illness is Absent }\end{array}$ & $\begin{array}{c}0.574=57.4 \% \\
\text { (NO factors present) }\end{array}$ & $\begin{array}{c}0.351=35.1 \% \\
\text { (All factors except Parental Mental } \\
\text { Illness present) }\end{array}$ \\
\hline \multirow[t]{2}{*}{$\begin{array}{l}\text { Parental } \\
\text { Substance } \\
\text { Use }\end{array}$} & $\begin{array}{l}\text { Parental } \\
\text { Substance Use } \\
\text { is Present }\end{array}$ & $\begin{array}{c}0.631=63.1 \% \\
\text { (Parental Substance } \\
\text { Use Only) }\end{array}$ & $\begin{array}{c}0.398=39.8 \% \\
\text { (All Factors Present) }\end{array}$ \\
\hline & $\begin{array}{l}\text { Parental } \\
\text { Substance Use } \\
\text { is Absent }\end{array}$ & $\begin{array}{c}0.574=57.4 \% \\
\text { (NO factors present) }\end{array}$ & $\begin{array}{c}0.341=34.1 \% \\
\text { (All factors except Parental } \\
\text { Substance Use present) }\end{array}$ \\
\hline \multirow[t]{2}{*}{$\begin{array}{l}\text { Parental } \\
\text { Incarceration }\end{array}$} & $\begin{array}{l}\text { Parental } \\
\text { Incarceration is } \\
\text { Present }\end{array}$ & $\begin{array}{c}0.638=63.8 \% \\
\text { (Parental } \\
\text { Incarceration Only) }\end{array}$ & $\begin{array}{c}0.398=39.8 \% \\
\text { (All Factors Present) }\end{array}$ \\
\hline & $\begin{array}{l}\text { Parental } \\
\text { Incarceration is } \\
\text { Absent }\end{array}$ & $\begin{array}{c}0.574=57.4 \% \\
\text { (NO factors present) }\end{array}$ & $\begin{array}{c}0.335=33.5 \% \\
\text { (All factors except Parental } \\
\text { Incarceration present) }\end{array}$ \\
\hline \multirow[t]{2}{*}{ Poverty } & $\begin{array}{l}\text { Poverty is } \\
\text { Present }\end{array}$ & $\begin{array}{c}0.463=46.3 \% \\
\text { (Poverty Only) }\end{array}$ & $\begin{array}{c}0.398=39.8 \% \\
\text { (All Factors Present) }\end{array}$ \\
\hline & $\begin{array}{l}\text { Poverty is } \\
\text { Absent }\end{array}$ & $\begin{array}{c}0.574=57.4 \% \\
\text { (No factors present) }\end{array}$ & $\begin{array}{c}0.507=50.7 \% \\
\text { (All factors except Poverty present) }\end{array}$ \\
\hline \multirow[t]{2}{*}{ PF 1} & PF 1 is Present & $\begin{array}{l}0.648=64.8 \% \\
\text { (PF } 1 \text { Only) }\end{array}$ & $\begin{array}{c}0.398=39.8 \% \\
\text { (All Factors Present) }\end{array}$ \\
\hline & PF 1 is Absent & $\begin{array}{c}0.574=57.4 \% \\
\text { (NO factors present) }\end{array}$ & $\begin{array}{c}0.325=32.5 \% \\
\text { (All factors except PF } 1 \text { present) }\end{array}$ \\
\hline \multirow[t]{2}{*}{ PF 2} & PF 2 is Present & $\begin{array}{l}0.643=64.3 \% \\
\text { (PF 2 Only) }\end{array}$ & $\begin{array}{c}0.398=39.8 \% \\
\text { (All Factors Present) }\end{array}$ \\
\hline & PF 2 is Absent & $\begin{array}{c}0.574=57.4 \% \\
\text { (NO factors present) }\end{array}$ & $\begin{array}{c}0.330=33.0 \% \\
\text { (All factors except PF } 2 \text { present) }\end{array}$ \\
\hline \multirow[t]{2}{*}{ PF 3} & PF 3 is Present & $\begin{array}{l}0.401=40.1 \% \\
\text { (PF } 3 \text { Only) }\end{array}$ & $\begin{array}{c}0.398=39.8 \% \\
\text { (All Factors Present) }\end{array}$ \\
\hline & PF 3 is Absent & $\begin{array}{c}0.574=57.4 \% \\
\text { (NO factors present) }\end{array}$ & $\begin{array}{c}0.570=57.0 \% \\
\text { (All factors except PF } 3 \text { present) }\end{array}$ \\
\hline \multirow[t]{2}{*}{ PF 4} & PF 4 is Present & $\begin{array}{l}0.496=49.6 \% \\
\text { (PF } 4 \text { Only) }\end{array}$ & $\begin{array}{c}0.398=39.8 \% \\
\text { (All Factors Present) }\end{array}$ \\
\hline & PF 4 is Absent & $\begin{array}{c}0.574=57.4 \% \\
\text { (NO factors present) }\end{array}$ & $\begin{array}{c}0.475=47.5 \\
\text { (All factors except PF } 4 \text { present) }\end{array}$ \\
\hline \multirow[t]{2}{*}{ PF 5} & PF 5 is Present & $\begin{array}{l}0.566=56.6 \% \\
\text { (PF } 5 \text { Only) }\end{array}$ & $\begin{array}{c}0.398=39.8 \% \\
\text { (All Factors Present) }\end{array}$ \\
\hline & PF 5 is Absent & $\begin{array}{c}0.574=57.4 \% \\
\text { (NO factors present) }\end{array}$ & $\begin{array}{c}0.406=40.6 \% \\
\text { (All factors except PF } 5 \text { present) }\end{array}$ \\
\hline \multirow[t]{2}{*}{ PF 6} & PF 6 is Present & $\begin{array}{l}0.444=44.4 \% \\
\text { (PF } 6 \text { Only) }\end{array}$ & $\begin{array}{l}0.398=39.8 \% \\
\text { (All Factors Present) }\end{array}$ \\
\hline & PF 6 is Absent & $\begin{array}{c}0.574=57.4 \% \\
\text { (NO factors present) }\end{array}$ & $\begin{array}{c}0.527=52.7 \% \\
\text { (All factors except PF } 6 \text { present) }\end{array}$ \\
\hline
\end{tabular}


Table 39

Predicted Probability of Drug Use

\begin{tabular}{|c|c|c|c|}
\hline \multicolumn{2}{|l|}{ Factors } & \multirow{2}{*}{$\begin{array}{l}\text { Effects when all other } \\
\text { factors are absent } \\
0.593=59.3 \% \\
\text { (Parental Mental } \\
\text { Illness Only) } \\
\end{array}$} & \multirow{2}{*}{$\begin{array}{l}\text { Effects when all other factors are } \\
\text { present } \\
0.567=56.7 \% \\
\text { (All Factors Present) }\end{array}$} \\
\hline $\begin{array}{l}\text { Parental } \\
\text { Mental Illness }\end{array}$ & $\begin{array}{l}\text { Parental Mental } \\
\text { Illness is } \\
\text { Present }\end{array}$ & & \\
\hline & $\begin{array}{l}\text { Parental Mental } \\
\text { Illness is Absent }\end{array}$ & $\begin{array}{c}0.576=57.6 \% \\
\text { (NO factors present) }\end{array}$ & $\begin{array}{c}0.550=55.0 \% \\
\begin{array}{c}\text { (All factors except Parental Mental } \\
\text { Illness present) }\end{array}\end{array}$ \\
\hline \multirow[t]{2}{*}{$\begin{array}{l}\text { Parental } \\
\text { Substance } \\
\text { Use }\end{array}$} & $\begin{array}{l}\text { Parental } \\
\text { Substance Use } \\
\text { is Present }\end{array}$ & $\begin{array}{c}0.618=61.8 \% \\
\text { (Parental Substance } \\
\text { Use Only) }\end{array}$ & $\begin{array}{c}0.567=56.7 \% \\
\text { (All Factors Present) }\end{array}$ \\
\hline & $\begin{array}{l}\text { Parental } \\
\text { Substance Use } \\
\text { is Absent }\end{array}$ & $\begin{array}{c}0.576=57.6 \% \\
\text { (NO factors present) }\end{array}$ & $\begin{array}{c}0.524=52.4 \% \\
\text { (All factors except Parental } \\
\text { Substance Use present) }\end{array}$ \\
\hline \multirow[t]{2}{*}{$\begin{array}{l}\text { Parental } \\
\text { Incarceration }\end{array}$} & $\begin{array}{l}\text { Parental } \\
\text { Incarceration is } \\
\text { Present }\end{array}$ & $\begin{array}{c}0.658=65.8 \% \\
\text { (Parental Incarceration } \\
\text { Only) }\end{array}$ & $\begin{array}{c}0.567=56.7 \% \\
\text { (All Factors Present) }\end{array}$ \\
\hline & $\begin{array}{l}\text { Parental } \\
\text { Incarceration is } \\
\text { Absent }\end{array}$ & $\begin{array}{c}0.576=57.6 \% \\
\text { (NO factors present) }\end{array}$ & $\begin{array}{c}0.481=8.1 \% \\
\text { (All factors except Parental } \\
\text { Incarceration present) }\end{array}$ \\
\hline \multirow[t]{2}{*}{ Poverty } & $\begin{array}{l}\text { Poverty is } \\
\text { Present }\end{array}$ & $\begin{array}{l}0.510=51.0 \% \\
\text { (Poverty Only) }\end{array}$ & $\begin{array}{c}0.567=56.7 \% \\
\text { (All Factors Present) }\end{array}$ \\
\hline & $\begin{array}{l}\text { Poverty is } \\
\text { Absent }\end{array}$ & $\begin{array}{c}0.576=57.6 \% \\
\text { (NO factors present) }\end{array}$ & $\begin{array}{c}0.631=63.1 \% \\
\text { (All factors except Poverty } \\
\text { present) }\end{array}$ \\
\hline \multirow[t]{2}{*}{ PF 1} & PF 1 is Present & $\begin{array}{l}0.661=66.1 \% \\
\text { (PF 1 Only) }\end{array}$ & $\begin{array}{c}0.567=56.7 \% \\
\text { (All Factors Present) }\end{array}$ \\
\hline & PF 1 is Absent & $\begin{array}{c}0.576=57.6 \% \\
\text { (NO factors present) }\end{array}$ & $\begin{array}{c}0.477=47.7 \% \\
\text { (All factors except PF } 1 \text { present) }\end{array}$ \\
\hline \multirow[t]{2}{*}{ PF 2} & PF 2 is Present & $\begin{array}{c}0.672=67.2 \% \\
\text { (PF 2 Only) }\end{array}$ & $\begin{array}{c}0.567=56.7 \% \\
\text { (All Factors Present) }\end{array}$ \\
\hline & PF 2 is Absent & $\begin{array}{c}0.576=57.6 \% \\
\text { (NO factors present) }\end{array}$ & $\begin{array}{c}0.465=46.5 \% \\
\text { (All factors except PF } 2 \text { present) }\end{array}$ \\
\hline \multirow[t]{2}{*}{ PF 3} & PF 3 is Present & $\begin{array}{l}0.496=49.6 \% \\
\text { (PF } 3 \text { Only) }\end{array}$ & $\begin{array}{c}0.567=56.7 \% \\
\text { (All Factors Present) }\end{array}$ \\
\hline & $\mathrm{PF} 3$ is Absent & $\begin{array}{c}0.576=57.6 \% \\
\text { (NO factors present) }\end{array}$ & $\begin{array}{c}0.644=64.4 \% \\
\text { (All factors except PF } 3 \text { present) }\end{array}$ \\
\hline \multirow[t]{2}{*}{ PF 4} & PF 4 is Present & $\begin{array}{l}0.438=43.8 \% \\
\text { (PF } 4 \text { Only) }\end{array}$ & $\begin{array}{c}0.567=56.7 \% \\
\text { (All Factors Present) }\end{array}$ \\
\hline & PF 4 is Absent & $\begin{array}{c}0.576=57.6 \% \\
\text { (NO factors present) }\end{array}$ & $\begin{array}{c}0.696=69.6 \% \\
\text { (All factors except PF } 4 \text { present) }\end{array}$ \\
\hline \multirow[t]{2}{*}{ PF 5} & PF 5 is Present & $\begin{array}{c}0.517=51.7 \% \\
\text { (PF 5 Only) }\end{array}$ & $\begin{array}{c}0.567=56.7 \% \\
\text { (All Factors Present) }\end{array}$ \\
\hline & PF 5 is Absent & $\begin{array}{c}0.576=57.6 \% \\
\text { (NO factors present) }\end{array}$ & $\begin{array}{c}0.625=62.5 \% \\
\text { (All factors except PF } 5 \text { present) }\end{array}$ \\
\hline \multirow[t]{2}{*}{ PF 6} & PF 6 is Present & $\begin{array}{l}0.573=57.3 \% \\
\text { (PF 6 Only) }\end{array}$ & $\begin{array}{c}0.567=56.7 \% \\
\text { (All Factors Present) }\end{array}$ \\
\hline & PF 6 is Absent & $\begin{array}{c}0.576=57.6 \% \\
\text { (NO factors present) }\end{array}$ & $\begin{array}{c}0.570=57.0 \% \\
\text { (All factors except PF } 6 \text { present) }\end{array}$ \\
\hline
\end{tabular}


Tables 33-39 illustrate that the impact of protective factors on child outcomes varies widely based on the outcome. The probability of school failure showed an impressive $50 \%$ decrease when all protective factors were present. The probabilities of alcohol use and drug use decrease slightly (17.6\% and $0.9 \%$ respectively). Other outcomes, however, actually showed an increase in probability. Criminal behaviors, being arrested, and behavioral difficulties were all shown to have an increased probability (approximately 5-15\%) of occurring with the protective factors.

The final chapter of this study will examine more fully the implications of the study findings. Each research question will be discussed at length to determine if the findings of the study support or reject the proposed hypotheses. Additionally, other areas of discussion will include implications for policy and practice, weaknesses and limitations of the study and areas for future research. 


\section{CHAPTER V}

\section{DISCUSSION}

Negative child outcomes have been shown to be predicted from four primary parental risk factors: parental mental illness, parental substance use, parental incarceration, and poverty. The aim of this study was to explore the relationship between four parental risk factors and seven child outcomes (school failure, criminal behaviors, being arrested, behavioral difficulties, emotional difficulties, alcohol use, and drug use). Two specific questions were addressed to achieve this aim.

1. To what degree do parental risk factors influence child outcomes?

2. Are child outcomes more significantly linked to any one parental risk factor over another?

Children in the sample were participants in the Children at Risk program, which was implemented in five communities across the United States. Participants in the program were required to meet several admission criteria showing that they were at risk of negative outcomes. Therefore, all participants in the study were identified as being at risk either because of familial, school, or personal characteristics. 
Due to the use of a secondary data set the current sample of children cannot be considered to be representative of the general population. All children were identified by the original researchers to be high risk in order to be eligible to participate in the intervention originally being tested. The prevalence of each of the risk factors is higher in this sample than in the general population. Nationally, $2 \%$ of children have an incarcerated parent (Johnson \& Waldfogel, 2004), the poverty rate in the United States is approximately $13 \%$ (Corcoran \& Chaudry, 1997), approximately $6 \%$ of children have a parent addicted to substances (Grant, 2000) and mentally ill parents are just as likely as those who are not mentally ill to parent at least one child (Ackerson, 2003). In the current sample $13 \%$ of children have a mentally ill parent, $11 \%$ have a parent that uses substances, $17 \%$ have an incarcerated parent, and $70 \%$ live in poverty. All of these percentages represent a higher prevalence of risk factors among this sample than in the general population of children.

Multiple risk models have been tested in the literature, but the important contribution of this study is the addition of parental incarceration as a risk factor. Parental incarceration has been inadequately studied as it relates to child outcomes and the vast majority of research on the subject does not examine the risk within the context of other risk factors in children's lives. Additionally, the current study utilizes a statistical method, multivariate probit regression, which has been rarely used in the field of social work and has not been applied to a multiple risk model that examines the risks identified in this study. 
The results from this study demonstrate that: (a) as risk factors increase the probability of negative child outcomes also increase; (b) all of the parental characteristics identified as risk factors were shown to have a significant impact on one or more child outcomes; (c) specific parental risk factors seem to contribute to specific child outcomes; (d) children with a parent incarcerated are more likely than those with other parental risk factors to display negative outcomes; and (e) participation in crime, being arrested, and drug use were found to be most impacted, showing significance on at least two risk factors. A discussion of these results as they relate to the two primary research questions follows.

\section{Research Questions Addressed}

\section{Research question one.}

To what degree do parental risk factors (parental mental illness, parental substance use, parental incarceration, and poverty) influence child outcomes? It was hypothesized that the presence of multiple parental risk factors would increase the likelihood that children would experience negative child outcomes. To test this hypothesis a multivariate probit regression was used. Previous research on multiple risk models asserts that the type of risk present in a child's life is not as important as the overall number of risks (Deater-Deckard, Dodge, Bates, \& Pettit, 1998; Greenberg et al., 1999; Sameroff \& Seifer, 1983; Sameroff, et al., 1987; Williams, et al., 1990). As the number of risks increase so does the probability of negative outcomes. The current study makes a substantive contribution to the field of social work by testing this hypothesis when a new risk 
factor, parental incarceration, is added to the model. A burgeoning field of research is beginning to examine the impact of parental incarceration on child outcomes, but there is a deficit in the research when it comes to examining parental incarceration within the context of multiple other risks.

To test this hypothesis a risk index was created from existing data and each child was assigned a score between 0 and 4 . The index was a simple addition of the number of risk factors that were present in each child's life. A multivariate probit regression model was run using the risk index score as the independent variable. The results of that analysis indicate that an accumulation of risk does significantly impact several of the child outcomes being examined. Criminal behaviors and being arrested were most significantly impacted by an. increasing number of risk factors and behavioral difficulties approached significance. Interestingly, alcohol use and drug use were not found to be significantly impacted by an increasing number of risk factors. This finding suggests that a simple accumulation of risk may not affect all outcomes in the same way.

When examining the effects of each independent variable on outcome probabilities it is possible to see the percentage of change in the risk of experiencing negative outcomes when there are one or multiple risks present. All of the dependent variables, excluding emotional difficulties, showed an increase in negative outcomes as risk increased. The risk of school failure increased by $7 \%$ when comparing no risk factors present in the child's life to all four risk factors being present. The same comparison showed criminal behaviors 
increasing by $36 \%$, getting arrested increased by $33 \%$, behavioral difficulties by $19 \%$, alcohol use by $11 \%$, and drug use by $11 \%$. Additionally, the large majority of outcomes increased when the number of risk factors increased incrementally from 1 factor to 3 factors to 4 factors. This suggests that as the presence of risk increases negative child outcomes increase, however, it does not make it possible for the researcher to determine whether one risk factor has a greater impact on a particular outcome over another. A simple assumption that increased risk leads to increased negative outcomes may underestimate the impact of specific risk factors on specific outcomes. If this assumption were true it would be expected that each probability of each outcome would increase in approximately the same way on all comparisons. The current analysis does not support this.

The findings of this study support the hypothesis that multiple parental risk factors increase the likelihood that a child will experience negative outcomes. However, findings further suggest that specific risk factors contribute to specific outcomes and that is it not simply the presence of any random risk factor that contributes to negative outcomes. To expand the analysis a second research question was examined

\section{Research question two.}

Are child outcomes more significantly linked to any one parental risk factor over another? It was hypothesized that specific child outcomes are more significantly linked to specific risk factors. 
Researchers have established that multiple risk factors increase the likelihood of negative outcomes (Greenberg, et al., 1999; Sameroff, et al., 1987; Williams, et al., 1990). As risk increases negative outcomes increase. The results of the current study supports these findings, however, these findings suggest that it is not simply the presence of increased risk that contributes to negative outcomes, but rather that specific risk factors increase the likelihood that specific negative outcomes occur. For example, the presence of parental incarceration and parental substance use have been shown to significantly impact the likelihood that a child will engage in criminal behaviors, but these factors, in the current study, do not increase the likelihood that a child will have emotional difficulties or fail in school. This suggests that specific risks are linked to specific outcomes.

All of the parental risk factors identified in the study were found to have a significant impact on at least one child outcome. Seven child outcomes were examined: school failure, involvement in criminal acts, being arrested, behavioral difficulties, emotional difficulties, alcohol use and drug use. Emotional difficulties were not significantly impacted by any of the identified parental characteristics. Additionally, none of the outcome variables were shown to be significantly impacted by more than two risk factors.

Parental incarceration and parental mental illness were shown to be linked to the most outcomes. Parental mental illness was the only risk factor shown to have a significant impact on school failure, when the effects of other risk factors were controlled for. Additionally, behavioral difficulties showed a link to only 
parental mental illness. This finding suggests that other risk factors believed to play a role in those negative outcomes may not contribute a significant amount of risk when parental mental illness is present and the seriousness of parental mental illness may trump the negative effects of other risks factors.

Another risk factor shown to have a significant impact on multiple outcomes was parental incarceration. Parental incarceration significantly impacted the largest number of outcomes, with significance $(p<0.05)$ on three outcomes (criminal behaviors, being arrested, drug use) and the risk factor approached significance $(p<0.10)$ on two other outcomes (behavioral difficulties and alcohol use). Again, this finding suggests that the risk posed by parental incarceration may overrule the negative effects of other risk factors.

Interestingly, the two most significant risk factors (parental mental illness and parental incarceration) were found to impact different child outcomes. The only overlap in the outcomes significantly impacted was the effect on whether a child had been arrested. All other outcomes were impacted differently by the two risk factors. Parental mental illness significantly impacted school failure and behavioral difficulties, whereas parental incarceration significantly impacted criminal behaviors and drug use. This finding further supports the argument that it is not simply a presence of risk, any risk, which leads to negative outcomes but rather that specific risk factors put children as risk of displaying specific negative outcomes.

Parental incarceration and parental substance use were shown to have the most significant impact on criminal behaviors when examining the impact of 
each risk factor separately. Both factors increased the likelihood of engaging in criminal acts by approximately $15 \%$ when other risk factors were controlled for. Parental incarceration and parental mental illness were shown to have the most significant impact on being arrested when examining the impact of each risk factor separately. Both factors increased the likelihood of getting arrested by approximately $10 \%$. Parental incarceration and poverty were shown to have the most significant impact on drug use when examining the impact of each risk factor separately. Parental incarceration increased the likelihood of drug use by $11 \%$. Interestingly, poverty was shown to decrease the likelihood of both drug use and alcohol use by approximately $10 \%$ suggesting that it may be a protective factor against drug use. This finding is contradictory to research finding in the literature on the impact of poverty on children (Corcoran \& Chaudry, 1997; Duncan, et al., 1994; Duncan \& Rodgers, 1988; McLeod \& Shanahan, 1993). It is also interesting to take note of the risk factors that were not found to significantly impact child outcomes. Thousands of dollars have been spent over the years to examine the effects of poverty on children and families. The findings of this study, however, do not show poverty as significantly impacting child outcomes when the other risks are controlled for. This suggests that perhaps it is not poverty, but other risks that often occur with poverty, that lead to negative outcomes. In which case, it can be argued that resources used to examine the impact of poverty would be better used to research other risks that often occur in families not touched by poverty (such as parental mental illness and parental substance use). 
The notion that specific risk factors contribute to specific outcomes is somewhat contradictory of previous research that asserts that it is simply the accumulation of risk, and not specific risk factors, that contribute to negative child outcomes. These findings challenge a fundamental assumption of previous multiple risk models-a simple accumulation of risk, regardless of the type of risk, lead to increased negative outcomes. The current findings attempt to recognize that not all risks are created equal and children who experience different types of risk respond differently and have different types of outcomes.

\section{Post-hoc Analyses and Opportunities for Future Research}

Two post hoc analyses were conducted in response to questions posed by the committee. The first identifies sub-groups in the sample based on the presence or absence of the risk factors. The second adds several protective factors to the original probit regression models.

\section{Identified sub-groups.}

As previously indicated this study was interested in the relationship between variables as opposed to looking at differences between sub-groups that exist within the sample (i.e. person centered analyses). Examination of the different permutations of risk and subgroup frequencies strongly suggest that future research, guided by a person centered approach may be informative. Examples of possible future analyses with this data may include latent class analysis and configural frequency analysis; both of these methods allow for the empirical identification of patterns/subgroups within the data (Cairns, Lars, \& Kagan, 1998) 


\section{Protective factors.}

Protective factors are those characteristics which are thought to protect children from negative outcomes in the presence of risk (Knoche, et al., 2007; Leon, 2003). Six protective factors (a child's positive attitude toward self, a child's belief that they are able to do things, that a child likes school, that a child finds school work interesting, a child's belief that getting arrested would ruin his/her future, and a child's belief that using drugs will lead to trouble) were identified and added to the probit regression model used to evaluate the research questions. School failure and criminal behaviors were both shown to be significantly reduced by specific protective factors. School failure was significantly reduced $(p<0.05)$ when two protective factors were present, that a child finds school work interesting and that a child enjoys being at school. Criminal behaviors were significantly reduced $(p<0.05)$ by a child finding school work interesting or having the belief that getting arrested would ruin his/her future. Among all the outcomes, emotional difficulty was most strongly influenced by protective factors, with a significant reduction in the outcome on three factors ( $a$ belief that they are able to do things, that they like being at school, and a belief that using drugs will lead to trouble).

Interestingly, similar to the risk factors, it appears that specific protective factors protect against specific outcomes. For example, a belief that getting arrested would ruin a child's future was shown to reduce criminal behaviors, but it did not significantly reduce drug or alcohol use. Additionally, it is interesting to note that the presence of protective factors significantly reduced the impact of 
two major risk factors_-parental mental illness and parental incarceration.

School failure was no longer found to be significantly impacted by parental mental illness and both being arrested and drug use were no longer found to be significantly impacted by parental incarceration. The protective factors that played the biggest role in the reduction of effects of risk were both related to a child's experience at school-that the child liked being at school and found school work interesting. The effect of other significant risks (such as parental substance use) and other outcomes on parental mental illness, poverty, and parental incarceration were not affected by the presence of protective factors. These post-hoc findings suggest that it is not simply the presence of protective factors that reduce negative child outcomes, but rather specific child characteristics (i.e. protective factors) that protect against some outcomes and not against others. Further study on this phenomenon would allow for a better understanding of the interplay between risk and protective factors in children's lives to reduce negative outcomes.

Implications for Policy and Practice

The results of this study have specific implications for today's social policies. The impact of parental incarceration is largely ignored by policy makers and the various branches of the criminal justice system, law enforcement, judicial, and corrections. Previous research on parental incarceration supports the findings of this study that parental incarceration has a significant impact on child outcomes. Parental incarceration in this study was shown to be more significantly linked to negative outcomes than any other parental risk factor. 
Policies today should reflect an increased awareness of the impact of parental incarceration on children. Imprisoning parents may lead to greater criminal behavior and alcohol/drug abuse in the next generation. This potential generational impact indicates a need to consider parenthood as an extenuating circumstance when sentences are determined and indicates a need for an increased use of community-based corrections when children will be impacted by the incarceration of a parent. When community corrections cannot be used it is important that children and their caregivers are given increased social support when a parent goes to prison. This support may include increased economic support (food stamps, Medicaid, TANF, etc.), intensive case management services to address ongoing needs, mental health services to cope with trauma, grief, and loss, and programs to assist families in staying better connected to one another during a parent's imprisonment.

Comprehensive policies need to be developed that address multiple risks and can better assess for the presence of various risks in a child's life. The findings of this study suggest that different risk factors are connected to different negative outcomes, but all negative outcomes have been shown in previous literature to contribute to difficulties throughout a person's lifespan. By examining the interconnection of various risk factors it will be easier to develop policies that break the cycle of poverty, drug use, criminal behavior, and untreated mental illness. The findings of this study support the need for policies and programs that address known risks, however, contrary to many policies today which focus on children identified as high risk, these findings support the 
argument that many times the presence of only one risk can lead to negative outcomes and therefore needs to be addressed by policies and programming. In fact, depending on the outcome being addressed, some risks are more critical to address. A school social worker trying to reduce the number of retentions in her school may be better served to create programming that addresses the impact of parental mental illness over poverty. No risk factor is insignificant and children do not have to have multiple risks in order for them to display negative outcomes. They just have to have the right kind of risk. The presence of only one risk factor or the presence of multiple risk factors will all significantly impact the likelihood of negative outcomes. Therefore, policy makers must take into account the specific outcomes being addressed. Policies need to be expanded to include children and neighborhoods that may not be considered high risk but may also face a significant likelihood of negative outcomes when certain risks are present.

\section{Weaknesses and Limitations of the Study}

There are a number of methodological limitations in the present study. First, secondary analysis was performed on data that was collected to serve the interest and perspective of the original researchers. The data was collected in order to test the effectiveness of an intervention over a period of years and was never intended to test the hypotheses of this research study. This resulted in a lack of control over the independent and dependent variables and some constructs were forced to be measured in a way they would not have been measured if collecting original data. Additionally, some variables of interest were not available in the data set and were therefore left out of the analysis. 
Secondly, the absence of ratio level data in the data set required some variables to be reduced to nominal level in order to include other nominal variables in the analysis that measured important constructs. This practice resulted in the loss of some detail on certain variables. Thirdly, the construct of parental incarceration was measured by whether a child had a parent or caregiver go to jail in the past year. This fails to capture the lifetime prevalence of parental incarceration. Fourthly, all of the children in the current study were identified as high risk by the original researchers and therefore there are not children in the sample who are low risk or who have no risks for negative outcomes. This makes it impossible to generalize the findings to other children outside of the sample population. Lastly, several possible child characteristics that have been shown to protect children against negative outcomes were not captured in the data set and therefore could not be controlled for in the analysis. Future research should include those protective factors that have been shown to decrease the risk of negative child outcomes. 


\section{REFERENCES}

Ackerson, B. J. (2003). Parents with serious and persistent mental illness: Issues in assessment and services. Social Work, 48(2), 187-194.

Anda, R. F., Whitfield, C. L., Felitti, V. J., Chapman, D. P., Edwards, F. J., \& Dube, S. R. (2002). Adverse childhood experiences, alcoholic parents, and later risk of alcoholism and depression. Psychiatric Services, 53(8), $1001-1009$.

Anderson, S., \& Newell, R. G. (2003). Simplified marginal effects in discrete choice models. Economics Letters, 81, 321-326.

Anthony, E. J. (1973). Mourning the psychotic loss of the parent. In E. J. Anthony \& C. Koupernik (Eds.), The child in his family (Vol. 2, pp. 255-264). New York: John Wiley \& Sons.

Anthony, E. J. (1976). How children cope in families with a psychotic parent. In E. N. Rexford, L. W. Sander \& T. Shapiro (Eds.), Monographs of the Journal of the American Academy of Child Psychiatry, Infant Psychiatry: A new synthesis (Vol. 2, pp. 239-247). New Haven and London: Yale University Press.

Arditti, J. A., Lambert-Shute, J., \& Joest, K. (2003). Saturday morning at the jail: Implications of incarceration for families and children. Family Relations, 52(3), 195. 
Austin, J., \& John, I. (2001). It's about time: America's imprisonment binge (3 ed.). Stamford, CT: Wadsworth.

Austin, J., Richards, C. R., \& Jones, R. S. (2003). Reducing Kentucky's prison population. Criminology and Public Policy.

Avalos-Jordan, N. (2008). A study of parental practices, poverty, and social connection to neighbors and their impact on children's emotional wellbeing and behavior. Unpublished Masters, California State University, Long Beach.

Bane, M. J., \& Ellwood, D. (1986). Slipping into and out of poverty: The dynamics of spells. Joumal of Human Resources, 21(1), 1-23.

Beardslee, W. R., Versage, E. M., \& Glastone, T. R. G. (1998). Children of affectively ill parents: A review of the past 10 years. Joumal of the American Academy of Child Adolescent Psychiatry, 37, 1134-1141.

Betson, D. M., \& Michael, R. T. (1997). Why so many children are poor. Children and Poverty, 7(2), 25-39.

Bilchik, S., Seymour, C., \& Kreisher, K. (2001). Parents in prison. Corrections Today, 63(7), 108.

Bloom, B., \& Steinhart, D. (1993). Why punish the children? A reappraisal of the children of incarcerated mothers in America. San Francisco, CA: National Council on Crime and Delinquency.

Braman, D. (2004). Doing time on the outside: Incarceration and family in urban America. Ann Arbor: University of Michigan Press. 
Braman, D., \& Wood, J. (2003). From one generation to the next: How criminal sanctions are reshaping family life in urban America. In J. Travis \& M. Waul (Eds.), Prisoners once removed: The impact of incarceration and reentry on children, families, and communities. Washington, D.C.: The Urban Institute Press.

Brandwein, R. A. (2007). The not-so-tender trap: Family violence and child poverty. In B. A. Arrighi \& D. J. Maume (Eds.), Child poverty in America today (Vol. 1, pp. 211). Westport, Connecticut: Praeger Perspectives.

Brooks-Gunn, J., \& Duncan, G. J. (1997). The effects of poverty on children. Children and Poverty, 7(2), 55-71.

Browne, A., \& Bassuk, S. (1997). Intimate violence in the lives of homeless and poorly housed women: Prevalence and patterns in an ethnically diverse sample. American Joumal of Orthopsychiatry, 6(261-278).

Burchinal, M., Roberts, J. E., Hooper, S., \& Zeisel, S. A. (2000). Cumulative risk and early cognitive development: A comparison of statistical risk models. Developmental Psychology, 36(6), 793-807.

Cairns, R. B., Lars, B. R., \& Kagan, J. (Eds.). (1998). Methods and models for studying the individual. Thousand Oaks, CA: Sage Publications.

Callahan, K. L., \& Hilsenroth, M. J. (2005). Childhood sexual abuse and adult defensive functioning. Joumal of Nervous Mental Disorders, 193(7), 473479.

Casas-Gil, M. J., \& Navarro-Guzman, J. L. (2002). School characteristics among children of alcoholic parents. Psychological Reports, 90(1), 341-348. 
Cauthen, N. K., \& Fass, S. (2008). Measuring poverty in the United States. New York: Columbia University: National Center for Children in Povertyo. Document Number)

Chapman, D. P., Dube, S. R., \& Anda, R. F. (2007). Adverse childhood events as risk factors for negative mental health outcomes. Psychiatric Annals, 37(5), 359-364.

Chassin, L., Curran, P. J., Hussong, A. M., \& Colder, C. R. (1996). The relation of parent alcoholism to adolescent substance use: A longitudinal follow-up study. Joumal of Abnormal Psychology, 105(1), 70-80.

Chib, S., \& Greenberg, E. (1998). Analysis of multivariate probit models. Biometrika, 85(2), 347-361.

Clear, T. R. (2002). The problem with "Addition by Subtraction": The prison-crime relationship in low-income communities. In M. Mauer \& M. Chesney-Lind (Eds.), Invisible punishment: The collateral consequences of mass imprisonment. New York: The New Press.

Colder, C. R., Chassin, L., Stice, E. M., \& Curran, P. J. (1997). Alcohol expectancies as potential mediators of parent alcoholism effects on the development of adolescent heavy drinking. Joumal of Research on Adolescence, 7(4), 349-374.

Cooke, C. G., Kelley, M. L., Fals-Stewart, W., \& Golden, J. (2004). A comparison of the psychosocial functioning of children with drug-verses alcoholdependent fathers. The American Joumal of Drug and Alcohol Abuse, 30(4), 695-710. 
Cooper, R., \& Jordan, W. J. (2003). Cultural issues in comprehensive school reform. Urban Education, 38, 380-397.

Corcoran, M. E. (1995). Rags to rags. Annual Review of Sociology, 21, 237-267.

Corcoran, M. E., \& Chaudry, A. (1997). The dynamics of childhood poverty. Children and Poverty, 7(2), 40-54.

Costello, E. J., Keeler, G., P., \& Angold, A. (2001). Poverty, race/ethnicity, and psychiatric disorder: A study of rural children. American Joumal of Public Health, 91(9), 1494-1498.

Covington, S. S. (2003). A woman's journey home: Challenges for female offender. In J. Travis \& M. Waul (Eds.), Prisoners once removed: The impact of incarceration and reentry on children, families, and communities. Washington, D.C.: The Urban Institute Press.

Craig, E. A. (2004). Parenting programs for women with mental illness who have young children: A review. Australian and New Zealand Joumal of Psychiatry, 38, 923-928.

Dallaire, D. H. (2007). Incarcerated mothers and fathers: A comparison of risks for children and families. Family Relations, 56, 440-453.

Dalley, L. P. (2002). Policy implications relating to inmate mothers and their children: Will the past be prologue? The Prison Joumal, 82(2), 234-268.

Davenport, Y. B., Zahn-Waxler, C., Adland, M. L., \& Mayfield, A. (1984). Early child rearing practices in families with a manic depressive parent. American Joumal of Psychiatry, 141, 230-235. 
Deater-Deckard, K., Dodge, K., Bates, J. E., \& Pettit, G. S. (1998). Multiple risk factors in the development of externalizing behavior problems: Group and individual differences. Development and Psychopathology, 10, 469-493.

DOJ. (2007a). Key Facts at a Glance: Incarceration Rate 1980-2006. Retrieved 8/24/2008, 2008, from www.ojp.usdoj.gov/bjs/glance/tables/incrttab.htm

DOJ. (2007b). Prison Statistics. Retrieved 8/24/2008, 2008, from www.ojp.usdoj.gov/bjs/priosons.htm\#findings

Downey, G., \& Coyne, J. C. (1990). Children of depressed parents: An integrative review. Psychological Bulletin, 108(1), 50-76.

Downey, L., Engelberg, R. A., Curtis, J. R., Lafferty, W. E., \& Patrick, D. L. (2009). Shared priorities of end-of-life period. Joumal of Pain Symptom Management, 37(2), 175-188.

Duncan, G. J., Brooks-Gunn, J., \& Klebanov, P. K. (1994). Economic deprivation and early-childhood development. Child Development, 65(2), 296-318.

Duncan, G. J., \& Rodgers, W. (1987). Single-parent families: Are their economic problems transitory or persistent? Family Planning Perspectives, 19(4), $171-178$.

Duncan, G. J., \& Rodgers, W. (1988). Longitudinal aspects of childhood poverty. Joumal of Mamiage and Family, 50(4), 1007-1021.

Dyer, W. J. (2005). Prison, fathers, and identity: A theory of how incarceration affects men's paternal identity. Fathering, 3(3), 201-219.

Elsner, A. (2004). Gates of injustice: The crisis of America's prisons. New York: Prentice Hall. 
Ender, P. (2010). Applied categorical and nonnormal data analysis: Probit regression models. Retrieved 5/5/2010, from http://www.gseis.ucla.edu/courses/ed231c/notes3/probit1.html

Finkelstein, N., Rechberger, E., Russell, L. A., VanDeMark, N. R., Noether, C. D., O'Keefe, M., et al. (2005). Building resilience in children of mothers who have co-occurring disorders and histories of violence: Intervention model and implementation issues. Joumal of Behavioral Health Science \& Research, 32(2), 141-154.

Foster, H., \& Hagan, J. (2007). Incarceration and intergenerational social exclusion. Social Problems, 54(4), 399-433.

Furstenberg, F. F., Jr., Cook, T. D., Eccles, J., Elder, G. H., Jr., \& Sameroff, A. J. (1999). Managing to make it: Urban families and adolescent success. Chicago: University of Chicago Press.

Gabel, K., \& Johnston, D. (1995). Children of incarcerated parents. Lanham, MD: Lexington Books.

Garson, D. (2010). Log-linear, logit, and probit models. Retrieved 5/5/2010, 2010, from http://faculty.chass.ncsu.edu/garson/PA765/logit.htm

Gibbons, R. D., \& Wilcox-Gok, V. (1998). Health service utilization and insurance coverage: A multivariate probit analysis. Joumal of American Statistical Association, 93(441), 63-72.

Golden, R. (2005). War on the family: Mothers in prison and the families they leave behind. New York: Routledge. 
Grant, B. F. (2000). Estimates of US children exposed to alcohol abuse and dependence in the family. American Joumal of Public Health, 90(1), 112115.

Greenberg, M. T., Lengua, L. J., Coie, J. D., \& Pinderhughes, E. E. (1999).

Predicting developmental outcomes at school entry using a multiple-risk model: Four American communities. Developmental Psychology, 35(2), 403-417.

Greenberg, R. (2006). Children and families: Mothers who are incarcerated. Women \& Therapy, 29(3/4), 165-179.

Gutjahr, A. (2007). Child resilience program: An intervention for children of chronically mentally ill parents. Unpublished Dissertation, Spalding University, Louisville, KY.

Hagen, K. A., \& Myers, B. J. (2003). The effect of secrecy and social support on behavioral problems in children of incarcerated women. Joumal of Child and Family Studies, 12(2), 229-242.

Hahn, E., \& Soyer, R. (2005). Probit and logit models: Differences in the multivariate realm. George Washington University.

Hairston, C. F. (1995). Fathers in prison. In D. Johnston \& K. Gables (Eds.), Children of Incarcerated Parents. Lexington, MA: Lexington Books.

Hairston, C. F. (2007). Focus on children with incarcerated parents: An overview of the research literature: Annie E. Casey Foundationo. Document Number) 
Hairston, C. F., \& Oliver, W. (2006). Women's experiences with men's incarceration and reentry. Women, Girls \& Criminal Justice, 7(5), 65-80.

Hairston, C. F., \& Oliver, W. (2007). Domestic violence and prisoner reentry: Experiences of African American men and women. New York: Vera Institute of Justice.

Hairston, C. F., Rollin, J., \& Jo, H. (2004). Family connections during imprisonment and prisoners' community reentry. In Children, families, and the criminal justice system. Chicago, IL: University of Illinois at Chicago, Jane Addams College of Social Work, Jane Addams Center for Social Policy and Research.

Hanion, T. E., O'Grady, K. E., Bennett-Sears, T., \& Callaman, J. M. (2005). Incarcerated drug-abusing mothers: Their characteristics and vulnerability. The American Joumal of Drug and Alcohol Abuse, 1, 59-77.

Harpaz-Rotem, I., Rosenheck, R. A., \& Desai, R. (2006). The mental health of children exposed to maternal mental illness and homelessness. Community Mental Health Joumal, 42(5), 437-448.

Harrell, A. V., Cavanagh, S., \& Sridharan, S. (1998). Evaluation of the children at risk program in Austin, Texas; Bridgeport, Connecticut; Memphis, Tennessee; Savannah, Georgia; and Seattle, Washington; 1993-1997. Washington, D.C.: The Urban Instituteo. Document Number) Herivel, T., \& Wright, P. (2003). Prison nation: The warehousing of America's poor. New York: Routledge. 
Hill, J. (Ed.). (1996). Parental psychiatric disorder and the attachment relationship. Cambridge: University Press.

Hill, M. S. (1983). Trends in the economic situation of U.S. families and children 1970-1980. In R. R. Nelson \& F. Skidmore (Eds.), American families and the economy. Washington, D.C.: National Academy Press.

Hill, N. E., \& Taylor, L. C. (2004). Parental school involvement and children's academic achievement. Current Directions in Psychological Science, 31, $161-164$

Hinden, B. R., Biebel, K., Nicholson, J., \& Mehnert, L. (2005). The invisible children's project: Key ingredients of an intervention for parents with mental illness. Joumal of Behavioral Health Science \& Research, 32(4), $393-408$.

Johnson, E. I., \& Waldfogel, J. (2004). Children of incarcerated parents: Multiple risks and children's living arrangements. In M. Pattillo, D. Weiman \& B. Western (Eds.), Imprisoning America: The social effects of mass incarceration. New York: Russell Sage Foundation.

Johnson, R. (2002). Hard time: Understanding and reforming the prison. Belmont, CA: Wadsworth. Johnson, R. C. (2009). Ever-increasing levels of parental incarceration and the consequences for children. In S. Raphael \& M. A. Stoll (Eds.), Do prisons make us safer? New York: Russell Sage Foundation.

Johnston, D. (1995). Effects of parental incarceration. In K. Gabel \& D. Johnston (Eds.), Children of Incarcerated Parents. New York: Lexington Press. 
Jones, E. (2008). And how are the children? Paper presented at the National Symposium on Children of Incarcerated Parents, Kentucky.

Kampfner, C. J. (1995). Post-traumatic stress reactions in children of imprisoned mothers. In K. Gabel \& D. Johnston (Eds.), Children of incarcerated parents. New York: Lexington Books.

Kinner, S. A., Alati, R., Najman, J. M., \& Williams, G. M. (2007). Do paternal arrest and imprisonment lead to child behavior problems and substance use? A longitudinal analysis. Joumal of Child Psychology and Psychiatry, 48(11), 1148-1156.

Knoche, L. L., Givens, J. E., \& Sheridan, S. M. (2007). Risk and protective factors for children of adolescents: Maternal depression and parental sense of competence. Joumal of Child and Family Studies, 16, 684-695.

Knop, J., Penick, E. C., Jensen, P., Gabrielli, W., Nickel, E. J., \& Ebdrup, B. (2002). Predictors of alcoholism in sons of alcoholics at age 40. European Psychiatry, 17(1), 140 S.

Korenman, S., Miller, J. E., \& Sjaastad, J. E. (1995). Long-term poverty and child development in the United States: Results from the national longitudinal survey of youth. Children and Youth Services Review, 17(1/2), 127-151.

La Vigne, N. G., Davies, E., \& Brazzell, D. (2008). Broken bonds: Understanding and addressing the needs of children with incarcerated parents.

Washington, D.C.: Urban Institute Justice Policy Centero. Document Number) 
La Vigne, N. G., Naser, R. L., Brooks, L. E., \& Castro, J. (2005). Examining the effect of incarceration and in-prison family contact on prisoners' family relationships. Journal of Contemporary Criminal Justice, 21(4), 314-335.

Lareau, A. (1987). Social class differences in family-school relationships: The importance of cultural capital. Sociology of Education, 60, 73-85.

Lareau, A. (1996). Assessing parent involvement in school: A critical analysis. In A. Booth \& J. F. Dunn (Eds.), Family-school links: How do they affect educational outcomes? (pp. 57-64). Mahwah, NJ: Lawrence Erlbaum.

Lareau, A. (2000). Home advantage: Social class and parental intervention in elementary education (2nd ed.). New York: Rowman \& Littlefield.

Leon, K. (2003). Risk and protective factors in young children's adjustment to parental divorce: A review of the research. Family Relations, 52(3), 258270.

Lesner, W. F., \& Hillman, D. A. (1983). A developmental schema of creativity. Joumal of Creative Behavior, 17, 103-114.

Lewit, E. M., Terman, D. L., \& Behrman, R. E. (1997). Children and poverty: Analysis and recommendations. Children and Poverty, 7(2), 4-24.

Long, S. J. (1997). Regression models for categorical and limited dependent variables. London: SAGE Publications.

Mackintosh, V. H., Myers, B. J., \& Kennon, S. S. (2006). Children of incarcerated mothers and their caregivers: Factors affecting the quality of their relationships. Joumal of Child and Family Studies, 15(5), 581-596. 
Massie, H., \& Szajnberg, N. (2006). My life is a longing: Child abuse and its adult sequelea. Results of the Brody longitudinal study from birth to age 30 . International Joumal of Psychoanalysis, 87(Part 2), 471-496.

Mather, M., \& Adams, D. (2006). The risk of negative child outcomes in lowincome families: The Annie E. Casey Foundation and Population Reference Bureauo. Document Number)

Mather, M., \& Rivers, K. L. (2006). The concentration of negative child outcomes in low-income neighborhoods: The Annie E. Casey Foundation and Population Reference Bureauo. Document Number)

Mauer, M. (1999). Race to incarcerate: The sentencing project. New York: The New Press.

Mazza, C. (2002). And then the world fell apart: The children of incarcerated fathers. Families in Society, 83(5/6), 521.

McLeod, J. D., \& Shanahan, M. J. (1993). Poverty, parenting and children's mental health. American Sociological Review, 58(3), 351-366.

Miller, K. M. (2006). The impact of parental incarceration on children: An emerging need for effective interventions. Child and Adolescent Social Work Joumal, 23(4), 472-486.

Moe, A. M., \& Ferraro, K. J. (2006). Criminalized mothers: The value and devaluation of parenthood from behind bars. Women \& Therapy, 29(3/4), 135-164.

Moe, J., Johnson, J. L., \& Wade, W. (2007). Resilience in children of substance users: In their own words. Substance Use \& Misuse, 42, 381-398. 
Moses, M. (1995). Keeping incarcerated mothers and their daughters together: Girl Scouts beyond bars (No. 156217). Washington, D.C.: National Institute of Justiceo. Document Number)

Moses, M. (2006a). Correlating incarcerated mothers, foster care and motherchild reunifications. Corrections Today, October.

Moses, M. (2006b). Does parental incarceration increase a child's risk for foster care placement? [Electronic Version]. National Institute of Justice Joumal, 255. Retrieved 4/3/2008, from http://www.ojp.usdoj.gov/nij/journals/255/parental incarceration.html

Mowbray, C., Schwartz, S., Bybee, D., Spang, J., Rueba-Riedle, \& Oyersman, D. (2000). Mothers with a mental illness: Stressors and resources for parenting and living. Families in Society: The Joumal of Contemporary Human Services, 81(2), 118-129.

Mowbray, C. T., \& Mowbray, O. P. (2006). Psychosocial outcomes of adult children of mothers with depression and bipolar disorder. Joumal of Emotional and Behavioral Disorders, 14(3), 130.

Mumola, C. J. (2000). Incarcerated parents and their children (Special Report). Washington, D.C.: Bureau of Justice Statisticso. Document Number) Murray, J., \& Farrington, D. P. (2007). Effects of parental imprisonment on children. Crime and Justice: A Review of Research, 37.

Murray, J., Janson, C., \& Farrington, D. P. (2007). Crime in adult offspring of prisoners: a cross-national comparison of two longitudinal samples. Criminal Justice \& Behavior, 34(1), 133-149. 
Muthen, B. (1989). Dichotomous factor analysis of symptom data. Sociological Methods Research, 18, 19-65.

Myung, J. (2003). Tutorial on maximum likelihood estimation. Joumal of Mathematical Psychology, 47, 90-100.

NCCP. Basic facts about low-income children: Birth to age 18. Retrieved 9/1/2008, 2008, from www.nccp.org

Nurse, A. M. (2002). Fatherhood arrested: Parenting from within the juvenile justice system. Nashville: Vanderbilt University Press.

Oates, M. (1997). Patients as parents: The risk of children. British Joumal of Psychiatry, 170(32), 22-27.

Osborne, C., \& Berger, L. M. (2009). Parental substance abuse and child wellbeing. Joumal of Family Issues, 30(3), 341-370.

Oyersman, D., Bybee, D., \& Mowbray, C. (2002). Influences of maternal mental illness on psychological outcomes for adolescent children. Joumal of Adolescence, 25(6), 587-602.

Oyersman, D., Mowbray, C., Meares, P., \& Firminger, K. (2000). Parenting among mothers with a serious mental illness. American Joumal of Orthopsychiatry, 70(3), 296-315.

Petersilia, J. (2000). When prisoners return to the community: Political, economic and social consequences. National Institute of Justice, Nov 2000, 1-22.

Petersilia, J. (2001). Prisoner reentry: Public safety and reintegration challenges. The Prison Joumal, 81(3), 360-375. 
Phillips, S. D., Burns, B. J., Wagner, H. R., Kramer, T. L., \& Robbins, J. M. (2002). Parental incarceration among adolescents receiving mental health services. Journal of Child and Family Studies, 11(4), 385-399.

Pirkola, S., Isometsa, E., Aro, H., Kestila, L., Hamalaninen, J., Veijola, J., et al. (2005). Childhood adversities as risk factors for adult mental disorders. Social Psychiatry \& Psychiatric Epidemiology, 40, 769-777.

Poehlmann, J. (2005). Children's family environments and intellectual outcomes during maternal incarceration. Journal of Marriage and Family, 67(5), 1275.

Poehlmann, J., Shlafer, R. J., Maes, E., \& Hanneman, A. (2008). Factors associated with young children's opportunities for maintaining family relationships during maternal incarceration. Family Relations, 57(July 2008), 267-280.

Prison and Jail Inmates at Midyear 2002. (April 2003). Washington: Bureau of Justice Statisticso. Document Number)

Reiman, J. (1998). The rich get richer and the poor get prison. Boston: Allyn and Bacon.

Robins, L. N. (1978). Sturdy childhood predictors of adult antisocial behavior: Replications from longitudinal studies. Psychological Medicine, 8(61), 611622.

Roy, K. M., \& Dyson, O. L. (2005). Gatekeeping in context: Baby mama drama and the involvement of incarcerated fathers. Fathering, 3(3), 289-310. 
Sameroff, A. J., Bartko, W. T., Baldwin, A., Baldwin, C., \& Seifer, R. (1998).

Family and social influences on the development of child competence. In M. Lewis \& C. Feiring (Eds.), Families, risk, and competence. Mahwah, NJ: Lawrence Erlbaum.

Sameroff, A. J., \& Seifer, R. (1983). Familial risk and child competence. Child Development, 54(5), 1254-1268.

Sameroff, A. J., Seifer, R., Barocas, R., Zax, M., \& Greenspan, S. (1987). Intelligence quotient scores of 4-year-old children: Social environmental risk factors. Pediatrics, 79(3), 343-350.

SAMSHA. Critical issues for parents with mental illness and their families [Electronic Version]. National Mental Health Information Center, Sawhill, I. (1988). Poverty in the U.S.: Why is it so persistent? Joumal of Economic Literature, 26(3), 1073-1119.

Schultz, D., Tharp-Taylor, S., Haviland, A., \& Jaycox, L. (2009). The relationship between protective factors and outcomes for children investigated for maltreatment. Child Abuse \& Neglect, 33, 684-698.

Seeman, M. V. (1996). The mother with schizophrenia. In M. Gopfert, J. Webster \& M. V. Seeman (Eds.), Parental psychiatric disorder: Distressed parents and their families (pp. 190-200). Cambridge: University Press.

Smith, A., Krisman, K., Strozier, A. L., \& Marley, M. A. (2004). Breaking through the bars: Exploring the experiences of addicted incarcerated parents whose children are cared for by relatives. Families in Society, 85(2), 187 195. 
Solomon, P., \& Draine, J. (1995). Jail recidivism in a forensic case management program. Health and Social Work, 20(3), 167-177.

Swisher, R., \& Waller, M. R. (2008). Confining fatherhood: Incarceration and paternal involvement among nonresident white, African American, and Latino fathers. Joumal of Family Issues, 29(8), 1067-1088.

Sydsjo, G., Wadsby, M., \& Svedin, C. G. (2007). Life development for 20 pairs of children with and without psychosocial problems-A 16-year-long study with follow up. Nord J Psychiatry, 61(1), 19-26.

Tabachnick, B., \& Fidell, L. (2000). Using multivariate statistics (Vol. 4). Boston: Allyn and Bacon.

Tebo, M. G. (2006). A parent in prison. ABA Joumal, 92, 12-14.

Travis, J. (2002). Invisible punishment: An instrument of social exclusion. In M. M. a. M. Chesney-Lind (Ed.), Invisible punishment: The collateral consequences of mass imprisonment (pp. 15-36). New York: The New Press.

Travis, J., McBride, E. C., \& Solomon, A. L. (2003). Families left behind: The hidden costs of incarceration and reentry: The Urban Institute.

Travis, J., \& Ward, M. (2003). Prisoners once removed: The children and families of prisoners. In J. Travis \& M. Ward (Eds.), Prisoners once removed: The impact of incarceration and reentry on children, families and communities (pp. 1-29). Washington, D.C.: The Urban Institute Press.

Trembley, R., Vitaro, F., Nagin, D., Pagani, L., \& Seguin, J. R. (2003). The Montreal longitudinal and experimental study: Rediscovering the power of 
descriptions. In T. P. Thornberry \& M. D. Krohn (Eds.), Taking stock of delinquency: An overview of findings from contemporary longitudinal studies (pp. 205-254). New York: Kluwer Academic.

Tuerk, E. H., \& Loper, A. B. (2006). Contact between incarcerated mothers and their children: Assessing parenting stress. Joumal of Offender Rehabilitation, 43(1), 23-43.

UCLA, A. (2009). STATA Data Analysis Examples: Probit Regression. Retrieved December 20, 2009, 2009, from http://www.ats.ucla.edu/stat/stata/dae/probit.htm

Wakefield, S. (2007). The consequences of incarceration for parents and children. Unpublished Dissertation, University of Minnesota.

Walker, S. (2001). Sense and nonsense about crime and drugs: A policy guide (5 ed.). Belmont, CA: Wadsworth.

Waller, M. R., \& Swisher, R. (2006). Fathers' risk factors in fragile families: Implications for "healthy" relationships and father involvement. Social Problems, 53(3), 392-420.

Williams, S., Anderson, J., McGee, R., \& Silva, P. A. (1990). Risk factors for behavioral and emotional disorder in preadolescent children. Joumal of Academy of Child and Adolescent Psychiatry, 29(3), 413-419.

Williams, S., Anderson, J., McGree, R., \& Silva, P. A. (1990). Risk factors for behavioral and emotional disorder in preadolescent children. Joumal of Academy of Child and Adolescent Psychiatry, 29, 413-419. 


\section{CURRICULUM VITAE}

NAME:

ADDRESS:

DOB:

EDUCATION

\& TRAINING:
Melody L. Hyppolite

310 Artist Drive, Apartment B

Nashville, IN 47448

Elizabethtown, Kentucky-August 30, 1976

B.S., Psychology

Kentucky Wesleyan College

1994-1998

M.S.W., Social Work

Spalding University

2000-2002

Ph.D., Social Work

University of Louisville

2002-2010

PROFESSIONAL SOCIETIES: National Association of Social Workers

TEACHING: Research Methods I, Kent School of Social Work, University of Louisville, Fall 2003

Social Work and Criminal Justice, Kent School of Social Work, University of Louisville, Spring 2003 